\title{
The Parkland Natural Region of Alberta
}

\author{
One of a series of reports prepared for the \\ Special Places 2000 Provincial Coordinating Committee
}

\author{
by \\ Alberta Environmental Protection \\ Natural Resources Service \\ Recreation \& Protected Areas Division \\ Natural Heritage Planning and Evaluation Branch
}

November 1997 


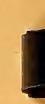

1

,

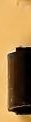

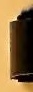

,

,

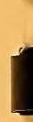

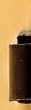

,

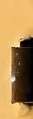

,

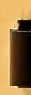

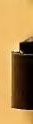

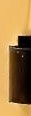

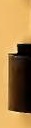

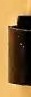

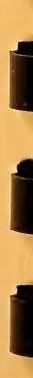




\title{
The Parkland Natural Region of Alberta
}

\author{
One of a series of reports prepared for the \\ Special Places 2000 Provincial Coordinating Committee
}

\author{
by \\ Alberta Environmental Protection \\ Natural Resources Service \\ Recreation \& Protected Areas Division \\ Natural Heritage Planning and Evaluation Branch
}

November 1997 


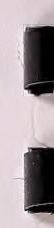

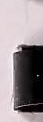

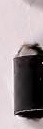

4

4

$-$

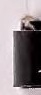

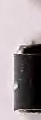

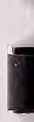

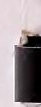

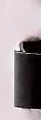

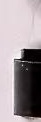

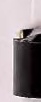

1

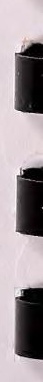




\section{Preface}

This report was prepared by staff of Environmental Protection and has not undergone review by professionals in the fields of protected areas, natural history and Parkland conservation. It is intended to provide background information on the Parkland Natural Region from a protected areas perspective. The suggestions and recommendations are left general and qualified. More specific suggestions and recommendations can be made on the basis of further detailed analysis of the identified blocks of landscapes suggested in this report for protected areas consideration. This further analysis will provide spatial coverage of each Level 1 Natural History Theme within distinct mapped polygons. If required, this analysis is available from Alberta Environmental Protection for all provincially, nationally and internationally ranked Environmentally Significant Areas. The data housed within and the capacity of the Alberta Natural Heritage Information Centre (ANHIC) in Edmonton were important for generating some of the findings of this report. The report contains professional comment and advice but it is not the policy of the Government of Alberta. 


\section{Table of Contents}

\section{Part 1 Introduction and Background}

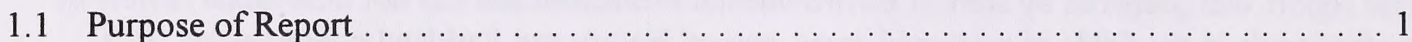

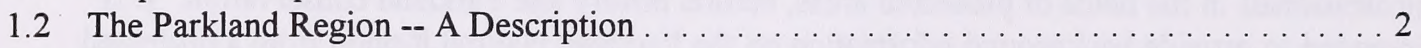

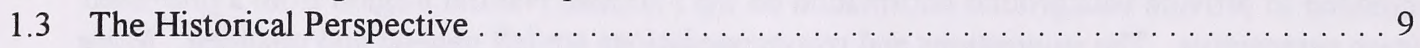

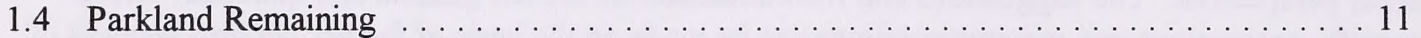

1.5 Fragmentation . . . . . . . . . . . . . . . . . . . . . . . . . . . . . 15

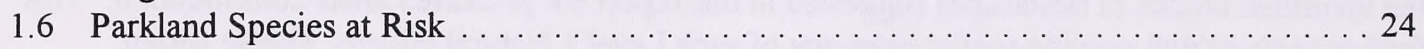

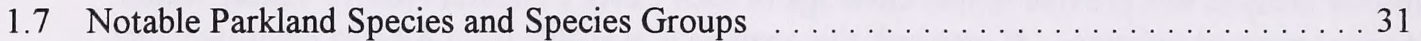

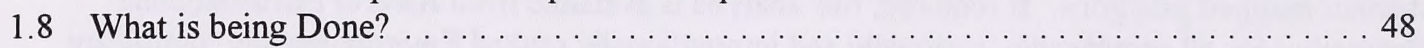

\section{Part 2 A Protected Areas Network for the Parkland Natural Region}

2.1 Designing a Protected Area's Network for the Parkland Region . . . . . . . . . . . . . 53

2.2 Identifying the Gaps in the System of Protected Lands in Alberta . . . . . . . . . . . . . 58

2.3 Filling the Gaps in the System of Protected Lands in Alberta's Parkland . . . . . . . . . . . . . . . . . . . . . . . 66

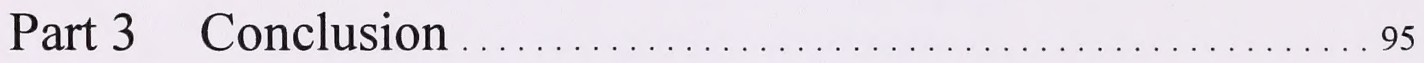

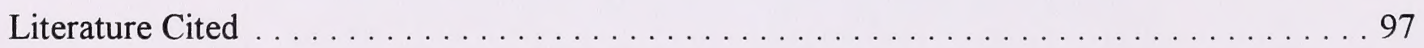

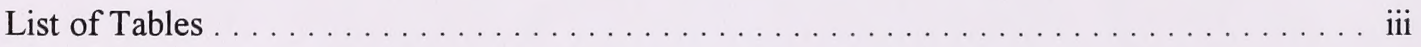

List of Maps $\ldots \ldots \ldots \ldots \ldots \ldots \ldots \ldots \ldots \ldots \ldots \ldots \ldots \ldots \ldots \ldots \ldots \ldots \ldots \ldots \ldots$ 


\section{List of Tables}

Table 1. Sizes and proportions of the three Parkland Subregions . . . . . . . . . . . . . 2

Table 2. Vegetation, soils and climatic differences of the three Subregions . . . . . . . . . 2

Table 3. Linear distances of roads and railways in the Parkland Natural Region . . . . . . . . 18

Table 4. Length/densities of roads in the Parkland Natural Region . . . . . . . . . . . . . . . . 19

Table 5. Areal extent of roads and railways in the Parkland Natural Region . . . . . . . . . . 20

Table 6. Wellsites in the Parkland . . . . . . . . . . . . . . . . . . . . 22

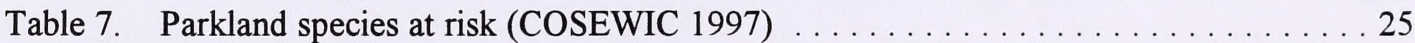

Table 8. The Status of Alberta Wildlife . . . . . . . . . . . . . . . . . . . 32

Table 9. Level 1 Natural History Theme targets of the three Parkland Subregions . . . . . . . . 59

Table 10. Examples of Special Themes in the Parkland Natural Region . . . . . . . . . . . 60

Table 11. Protected Areas in the Parkland Natural Region . . . . . . . . . . . . . . . . 62

Table 12. Level 1 NHT Theme Summary for the Central Parkland Subregion . . . . . . . . . . 64

Table 13. Level 1 NHT Theme Summary for the Foothills Parkland Subregion . . . . . . . . . 65

Table 14. Level 1 NHT Theme Summary for the Peace River Parkland Subregion . . . . . . . 66

Table 15. Environmentally Significant Area Studies in Alberta's Parkland Region . . . . . . . . 68

Table 16. Distribution, aerial extent and significance ratings of ESAs within the

Parkland Natural Region . . . . . . . . . . . . . . . . . . . . . . . . . 69

Table 17. Land Ownership Summary - Parkland Natural Region . . . . . . . . . . . . . . . . 70

Table 18. Land Ownership Summary - Central Parkland Subregion . . . . . . . . . . . . . . 73

Table 19. Central Parkland Subregion . . . . . . . . . . . . . . . . . . . . . . 73

Table 20. Theme Representation (Public Land) - Central Parkland . . . . . . . . . . . . . 76

Table 21. Land Ownership Summary - Foothills Parkland Subregion . . . . . . . . . . . . 84

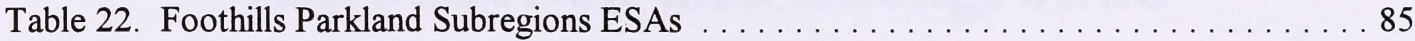

Table 23. Theme Representation (Public Land) - Foothills Parkland . . . . . . . . . . 86

Table 24. Land Ownership Summary - Peace River Parkland Subregion . . . . . . . . . . . 88

Table 25. Peace River Parkland Subregion ESAs . . . . . . . . . . . . . . . . . . . . . . 89

Table 26. Theme Representation (Public Land) - Peace River Parkland . . . . . . . . . . . . 90 


\section{List of Maps}

Page

Map 1. Alberta's Natural Regions and Subregions $\ldots \ldots \ldots \ldots \ldots \ldots \ldots$

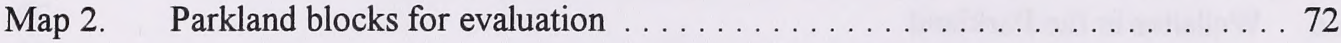

\section{Back of document:}

Map A. Land Ownership

Map B. Transportation Networks and Petroleum and Natural Gas Wellsites

Map C. Environmentally Significant Areas

Map D. Priorities for Special Places Level 1 Targets 


\section{PART 1}

\section{Introduction and Background}


Digitized by the Internet Archive in 2015 


\section{Chapter 1.1 Purpose of Report}

\subsubsection{Purpose}

This report is one of a series dealing with the province's Natural Regions and Subregions and was prepared, in part, for the Special Places Provincial Coordinating Committee (PCC). The purpose of this report is to provide the PCC with an analysis of the Parkland Natural Region from a landscape protection/biodiversity conservation perspective. This analysis will assist members of the PCC in evaluating and ranking candidate Special Places sites nominated by Albertans.

\subsubsection{Overview of Report Contents}

This report discusses the Parkland Natural Region and focuses on crown land. Chapter 1.1 provides background information on the reasons why this report was prepared. Chapter 1.2 presents a brief biophysical perspective of the Parkland biome in North America and in Canada, with more detailed information for Alberta. Chapter 1.3 provides an historical perspective and Chapter 1.4 discusses the resulting amount of Parkland remaining. Detailed information on ongoing fragmentation of Parkland ecosystems through linear disturbances is presented in Chapter 1.5. Chapters 1.6 and 1.7 review the results of historical trends on Parkland species.

The Parkland is one of the most heavily impacted Natural Regions in Alberta. It has changed dramatically over the last 75 to 100 years under the cumulative effects of roadways, urbanization, cultivation, livestock grazing, petroleum and natural gas development, mining, hydroelectric dams, irrigation developments, electrical transmission lines and other developments. These are all a necessary part of modern society and help to support the social and economic needs and other demands of its human population - locally, nationally and internationally. Human activity, however, has altered species, landscapes and the natural ecological processes of the Parkland.

Many individuals, organizations, agencies and industries recognize the value of restoring, reclaiming and rehabilitating damaged or degraded Parkland features, ecosystems and landscapes. Considerable effort and funds are devoted to this cause and progress has been made. Some aspects that are being considered in the task of conserving and restoring native Parkland are discussed in Chapter 1.8.

Along with restoration of damaged or degraded areas, there is a need to protect examples of Parkland ecosystems. This is dealt with in considerable detail in Part 2. The philosophy behind designing a protected area's network on provincial crown lands for the Parkland of Alberta is presented in Chapter 2.1. Chapter 2.2 outlines where gaps occur in the system of protected lands in the three Parkland Subregions in the province. Chapter 2.3 describes the process used to help focus on provincial crown lands that have the potential to fill identified gaps. The final three chapters (2.4 to 2.6) deal with each of the Subregions in the Parkland Natural Region and the locations of the best candidate areas to be considered for protection. 


\section{Chapter 1.2 Alberta's Parkland Natural Region - A Description}

Alberta's landscapes are divided into six natural regions based on broad differences in landscape patterns (Alberta Environmental Protection 1994b). These regions are further divided into a total of 20 Subregions, based on recurring patterns found within the larger natural region. The Parkland Natural Region is located in southern Alberta and consists of three Subregions (Map 1).

The Parkland Natural Region covers about 62,780 sq. km., or about $9.5 \%$ of Alberta (Table 1). The Central Parkland Subregion is the largest of the three Parkland Subregions, occupying over $53,000 \mathrm{~km}^{2}$ or about $8 \%$ of the area of Alberta.

Table 1. Sizes and proportions of the three Parkland Subregions (Alberta Environmental Protection 1994b).

\begin{tabular}{|c|c|c|c|}
\hline Subregion & Area $\left(\mathrm{km}^{2}\right)$ & $\begin{array}{c}\text { Subregion } \\
\text { as \% of } \\
\text { Alberta }\end{array}$ & $\begin{array}{c}\text { Subregion } \\
\text { as \% of } \\
\text { region }\end{array}$ \\
\hline Central Parkland & 53,413 & 8.1 & 85.5 \\
\hline Foothills Parkland & 4,402 & 0.7 & 7.0 \\
\hline Peace River Parkland & 4,665 & 0.7 & 7.5 \\
\hline
\end{tabular}

The three Subregions are separated primarily based on differing vegetation, climate and soils as shown in Table 2.

Table 2. Vegetation, soils and climatic differences of the three Subregions (after Achuff 1992)

\begin{tabular}{|l|l|l|l|}
\hline Subregion & \multicolumn{1}{|c|}{ Vegetation } & \multicolumn{1}{c|}{ Soils } & \multicolumn{1}{c|}{ Climate } \\
\hline $\begin{array}{l}\text { Central } \\
\text { Parkland }\end{array}$ & $\begin{array}{l}\text { plains rough fescue } \\
\text { aspen } \\
\text { balsam poplar }\end{array}$ & $\begin{array}{l}\text { Black and Dark Brown Chernozems } \\
\text { Dark Gray Chernozems and Luvisols } \\
\text { Solonetz }\end{array}$ & $\begin{array}{l}\text { few chinooks } \\
\text { cool and moist }\end{array}$ \\
\hline $\begin{array}{l}\text { Foothills } \\
\text { Parkland }\end{array}$ & $\begin{array}{l}\text { mountain rough } \\
\text { fescue, Idaho } \\
\text { fescue and oat grasses } \\
\text { aspen and willow }\end{array}$ & Black and Dark Brown Chernozems & $\begin{array}{l}\text { more chinooks } \\
\text { milder winters }\end{array}$ \\
\hline $\begin{array}{l}\text { Peace River } \\
\text { Parkland }\end{array}$ & $\begin{array}{l}\text { aspen } \\
\text { wheat and porcupine } \\
\text { grasses, sedges }\end{array}$ & $\begin{array}{l}\text { Luvisols } \\
\text { Solonetz }\end{array}$ & $\begin{array}{l}\text { few chinooks } \\
\text { coolest and } \\
\text { wettest }\end{array}$ \\
\hline
\end{tabular}

The following description of Alberta's Parkland Natural Region is taken from Natural Regions, Subregions and Natural History Themes of Alberta. A Classification for Protected Areas Management (Achuff 1992): 


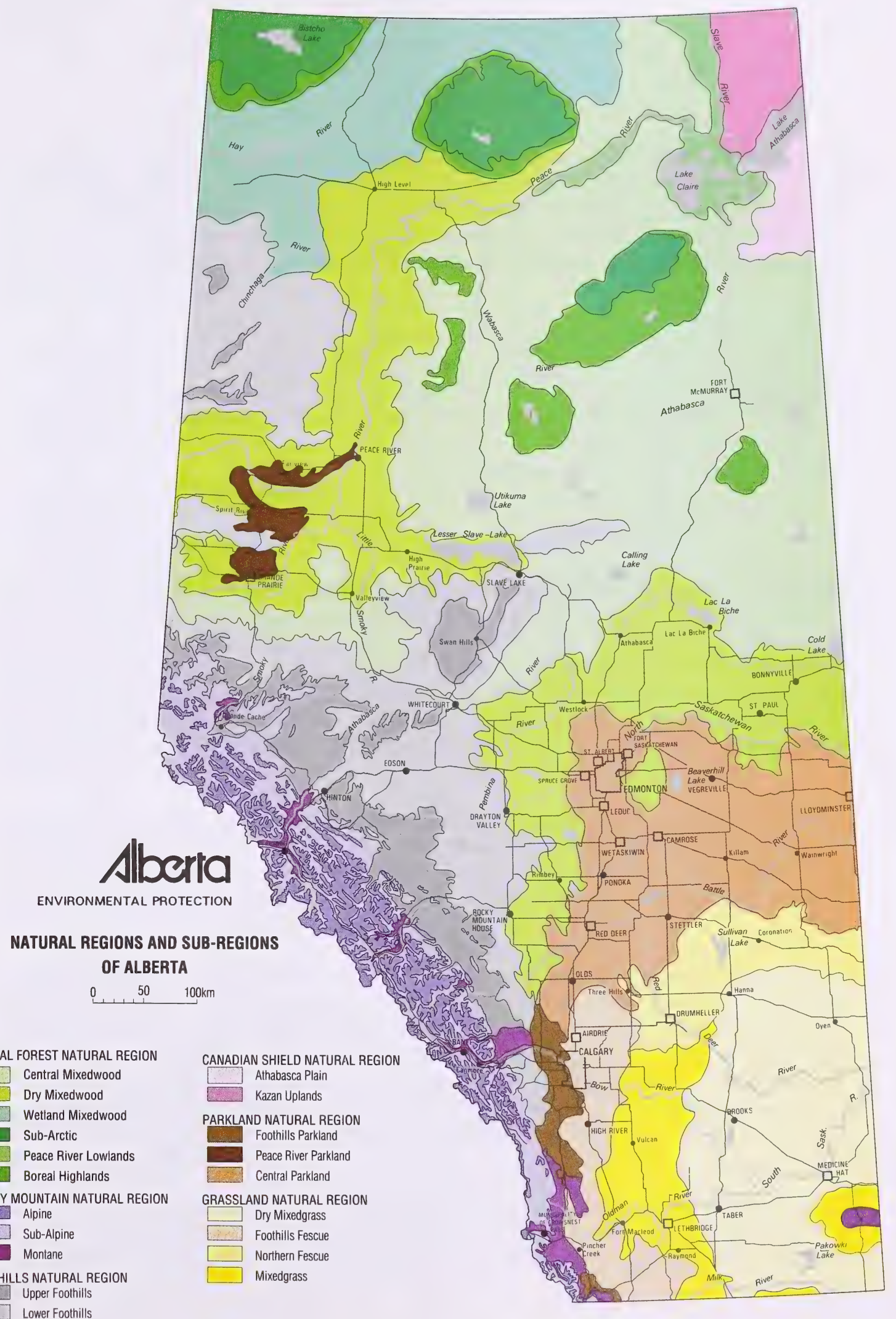



The Parkland Natural Region, with the exception of the Peace River Parkland Subregion, forms a broad transition between the drier grasslands of the plains and the coniferous forests of the Boreal Forest and the Rocky Mountains. Except for small tongues extending a short distance into the northern U.S., this region is confined to the prairie provinces of Canada. It consists of three Subregions - Central, Foothills and Peace River - which are separated on the basis of geographic location and major floristic differences.

The Parkland Natural Region is the most densely populated region in Alberta, with the greatest density in the Central Parkland Subregion. Land use has changed much of the native vegetation; the most extensive alteration has been in the Peace River Parkland and the least in the Foothills Parkland. Many vegetation types were not adequately documented before they were eliminated or greatly reduced.

\subsubsection{Central Parkland Subregion}

\section{Geology and Landforms}

The Central Parkland Subregion extends in a broad arc up to $200 \mathrm{~km}$ wide, north of the Grassland Natural Region and south of the Boreal Forest Natural Region. Surficial deposits include hummocky and ground moraines, glaciolacustrine deposits, coarse outwash, kame moraines, and dune fields. Moraines are most widespread, with kames locally extensive in eastern areas. The Neutral Hills are an excellent example of ice-thrust bedrock ridges. Elevations range from about $500 \mathrm{~m}$ where the Battle River enters Saskatchewan to around $1100 \mathrm{~m}$ in western portions. Numerous lakes and permanent wetlands occur throughout the Subregion. Many are slightly to strongly saline.

Local bedrock geology of the Central Parkland Subregion is primarily Cretaceous shale and sandstones from six dominant units; the Lea Park, Belly River, Bearpaw, Horseshoe Canyon, Wapiti and Paskapoo Formations, all of Upper Cretaceous age (Green 1970). Generally, the oldest bedrock units outcrop within the northeast portion of the study area, and progressively become younger toward the southwest.

Within the northeast corner of the Central Parkland, bedrock from the Lea Park Formation occurs and consists of dark grey shale, and pale grey glauconitic silty shale with ironstone concretions that were deposited within marine waters (Green 1970). To the south and southwest, grey to greenish grey, feldspathic, sandstone, clayey siltstones and green mudstones of the Belly River Formation occur (ibid.). This strata is mainly non-marine. Immediately to the west of the Belly River Formation and extending in a narrow band north to Beaverhill Lake is the Bearpaw Formation. This formation is described as silty, dark grey shales that were deposited within shallow marine waters (ibid.).

To the west, a complex of interbedded sandstones, mudstones, and shales of the Horseshoe Canyon Formation extend north to the Edmonton Area. This unit is characterized by rapid transitions between marine (shale \& limestone) and non-marine (ironstone and coal) strata (Green 

1970). The rapid changes in depositional environment are attributed to short-lived marine transgressions and regressions during orogenic events.

West of the Horseshoe Canyon Formation is the Paskapoo Formation that extends to the western border of the Central Parkland. The bedrock consists of fine grained sandstone, siltstone, and shales with minor interbeds of coal (Green 1970). North of the Edmonton area is the Wapiti Formation, described as grey feldspathic clayey sandstone, bentonitic mudstone with scattered coal beds.

Major rivers in the Central Parkland Subregion include the Battle, Vermilion and North Saskatchewan rivers.

\section{Climate}

Climatically, the Central Parkland Subregion is transitional between the warmer, drier grasslands and the cooler, moister forested areas of Alberta. It has a typical continental climate with cold winters, warm summers and low precipitation. The mean annual temperature is $2{ }^{\circ} \mathrm{C}$ with an average frost-free period of 95 days. Mean annual precipitation is $350-450 \mathrm{~mm}$.

\section{Soils}

Black and Dark Brown Chernozems predominate under grasslands while under aspen woodlands, Dark Gray Chernozems and Luvisolics are most common. A strip of Brown Solonetz soils runs through the centre of the Subregion from Vegreville, through Beaverhill Lake trending towards the Sullivan Lake area.

\section{Vegetation}

Within the Subregion, there is a continuum from south to north of grassland with groves of aspen, to aspen Parkland, to closed aspen forest. True Parkland vegetation with continuous aspen forest broken by grassland openings is now very rare due to large scale clearing. Elsewhere, native vegetation is scarce because of the high productivity of the soils for agriculture. Consequently, most of the remaining Parkland sites are on rougher terrain or Solonetzic soils.

Two major forest types occur on morainal and glaciolacustrine materials - aspen forest and, in the northern part of the Subregion as well as on moister sites in depressions, balsam poplar forest. Both are characterized by a dense, lush, species-rich understorey. The grassland vegetation of the 'parks' is essentially the same as that of the Northern Fescue Subregion. Rough fescue dominates most sites with western porcupine grass being important on south-facing slopes in the southern part of the Subregion and on Solonetzic soils. Shrub communities are more extensive in the northern portion of the Subregion and often extend in belts outward from the forest communities. Major species are snowberry, rose, chokecherry, and saskatoon. 


\section{Wildlife}

Animals of the Subregion are a mix of elements of the Northern Fescue Subregion and the boreal mixedwood Subregions. At the southern edge of the Subregion, grassland species such as Upland Sandpiper, Sprague's Pipit and Baird's Sparrow occur but become less common further north. Along the northern boundary, boreal forest species such as Woodchuck, Broad-winged Hawk and Rose-breasted Grosbeak are more common. Franklin's Ground Squirrel and Piping Plover range primarily in this Subregion.

Marshes and wetlands are a distinctive feature of this Subregion and provide important breeding and migrating habitat for many species of water and marsh birds. The three prairie provinces produce $60 \%$ of the waterfowl on the continent and waterfowl production in Alberta accounts for $40 \%$ of this total. Alberta's Central Parkland is part of one of the major production areas for North American waterfowl contributing significantly to the Central and Pacific flyways and, to a lesser extent, the Mississippi and Atlantic flyways. In addition, major concentrations of northern breeding shorebirds, ducks, geese, and swans stage on Alberta lakes during spring and fall migration.

Both breeding and staging waterfowl, but particularly breeding waterfowl, make significantly higher use of wetlands in the Parkland Natural Region than they do of wetlands in the Grassland Natural Region. In the Parkland, the evaporation rate is lower and, as a result, the summer loss of water is also smaller. In May, the density of potholes in The Parkland is twice that in the grasslands, and by July the differential is increased to three times due to drying out of wetlands in the grassland (Smith et al. 1964). Grassland potholes, while still valuable as staging lakes, are usually too shallow by midsummer to be of value to breeding and nesting fowl. Some species, such as pintails, northern shovelers, and gadwalls, seek grassland wetlands but others such as green-winged teal, lesser scaup, and bufflehead are more abundant in the Parkland Natural Region.

Fish habitat is limited for the most part to the region's major drainage features, including the Red Deer and Battle Rivers, and the larger, more permanent lakes and wetlands.

\subsubsection{Foothills Parkland Subregion}

\section{Geology and Landforms}

The Foothills Parkland Subregion occupies a narrow band along the eastern edge of the foothills from Calgary south to the Porcupine Hills, and from Pincher Creek south to the U.S. border in the Waterton Lakes National Park area. The topography is rougher than that of the Central Parkland Subregion, and elevations are higher, ranging to over $1300 \mathrm{~m}$ near Paine Lake. Surficial deposits include extensive areas of hummocky and ground moraine as well as more restricted areas of outwash and glaciolacustrine deposits along valleys. Extensive river terraces occur in some areas. 


\section{Climate}

The climate of the Foothills Parkland Subregion differs from that of the Central Parkland Subregion in having a greater frequency of chinooks and thus, a somewhat milder winter climate. There is also greater snowfall in late winter and early spring. Mean annual precipitation ranges from $650 \mathrm{~mm}$ in the far south to $500 \mathrm{~mm}$ in the northern part of the Subregion. The mean MaySeptember temperature is $12-13^{\circ} \mathrm{C}$ and the frost-free period averages 90 days.

\section{Soils}

Predominant soils in the forested areas are Black Chernozems with Dark Brown and Black Chernozems in the grasslands. Regosolics occur on active stream floodplains while Gleysolics occur in wetland sites.

\section{Vegetation}

Foothills Parkland generally forms a narrow, transitional band between the grasslands of the Foothills Fescue Subregion and the forests of the Montane Subregion. As in the Central Parkland Subregion, there is a continuum from grassland with groves, to forest with grassy parks, to closed deciduous forest. Because of rapid topographic and climatic change, the transition occurs over one to five kilometres. This compression results in small geographic areas being very diverse. The northern boundary has been placed near Calgary since this is the northern limit of a number of distinctive southwestern species.

The grassland is similar to the Foothills Fescue Subregion, a mountain rough fescue-oatgrass -mountain rough fescue, Idaho fescue, Parry's oatgrass and intermediate oatgrass -- community with a large diversity of forb and grass species. Aspen generally dominates upland forests with balsam poplar on moister sites. A distinctive characteristic of these woods in the southwestern part of the Subregion is large amounts of glacier lily which bloom in early to mid-May. Willow groveland, a distinctive community, occurs extensively in the northern part of the Subregion.

The grasslands have a greater variety and cover of forbs than does the Central Parkland Subregion. Dominant species include: sticky geranium, prairie crocus, woolly gromwell, northern bedstraw, golden bean, prairie sagewort, American sweet vetch, low larkspur, heartleaved buttercup, shooting star, and western wild parsley. Many plant species occur in the Foothills Fescue Subregion that are not found in the Central Parkland Subregion.

\section{Wildlife}

Many animal species that occur in the Central Parkland Subregion are absent here but other species give this Subregion a distinctive character. Rocky Mountain species in upland forests and shrublands include Dusky Flycatcher, MacGillivray's Warbler, Lazuli Bunting and White-crowned Sparrow. In the far south, Black-headed Grosbeaks and Blue Grouse are typical of aspen forests. 


\subsubsection{Peace River Parkland Subregion}

\section{Geology and Landforms}

The Peace River Parkland is characterized by broad, gently rolling plains on glacial lake deposits with scattered morainal uplands and deeply-incised, steep-sided river valleys. Mass wasting is common along stream valleys. The main portion is in the Grande Prairie and Peace River areas with smaller areas (mapped within the Dry Mixedwood Subregion) further north to Fort Vermilion. Most of the extensive grasslands of this Subregion have been cultivated and only small, scattered remnants are still in native cover.

\section{Climate}

The climate of the Peace River Parkland Subregion is similar to that of the Dry Mixedwood Subregion. The mean annual precipitation is $350-440 \mathrm{~mm}$. The mean May-September temperature is $13^{\circ} \mathrm{C}$ and the frost-free period averages 95 days. The Subregion has shorter, cooler summers and longer, colder winters than the other Parkland Subregions. It also has higher precipitation, less wind and lower evaporation.

\section{Soils}

The soils of the grasslands are mostly Solonetzic while those of the forested portion are mostly Luvisolics. The Solonetzic soils are an important factor in maintaining the grasslands here with fire and, possibly, climate playing a secondary role.

\section{Vegetation}

The Peace River Parkland consists of "relic" grassland communities on primarily solonetzic soils and upland forested communities primarily on till and fluvial deposits. Forested communities are now restricted to upland areas not cleared for agricultural uses and remnant grassland communities are found primarily along the river systems. Native vegetation in the Peace River Parkland has been significantly reduced because of extensive agricultural land clearing.

The upland forests of the Peace River Parkland occur mostly on till deposits and are virtually indistinguishable from those of the surrounding Mixedwood Boreal Forest. They are dominated by aspen and white spruce with lesser amounts of balsam poplar especially on wetter sites. The grasslands, on Solonetzic soils, are dominated by sedges, intermediate oat grass, western porcupine grass, bearded wheatgrass, old man's whiskers, and low goldenrod. Grasslands on steep, south-facing slopes are dominated by porcupine grass, sedges, and pasture sage. More northerly grasslands are a wheatgrass-sedge type. These isolated grasslands are also notable for disjunct species occurrences and the presence of species which have a more southerly or westerly distribution. 
Grassland communities within the Peace River Parkland are closely related to the Northern Fescue except for the absence of rough fescue. According to Achuff (1992), "the absence of rough fescue is not surprising since it is often absent from solentzic soils in the Central Parkland and Northern Fescue."

\section{Wildlife}

The close association and very slight gradation with the Boreal Dry Mixedwood Natural Subregion (of the Boreal Forest Natural Region) gives the Peace River Parkland a character very much resembling boreal mixedwood forests. This character is reflected in the resident mammal fauna, which includes 13 species which are not found in the Central Parkland Subregion. Few animals of Central Parkland grassland habitats are present.

Like other Parkland Subregions, the Peace River Parkland is dotted with productive wetlands which provide habitat for a variety of waterfowl, shorebirds and marsh birds. Lakes and ponds of the Peace River Parkland constitute a major nesting area for the rare Trumpeter Swan. It is one of the rarest swans in the world and breeding habitats in the Peace River Parkland and adjacent areas of the Foothills Natural Region and Boreal Forest Natural Region are critical.

The Peace River Parkland contains 17 species of fish. Ten species of fish occur in the Peace River Parkland and not in the Central Parkland Subregion. The more diverse fish assemblage of the Peace River Parkland is largely due to the fact that this region is bisected by a much larger river course, the Peace River, than any that exists in the Central Parkland. Three species of fish barely range into Alberta along the upper Peace River: Redside Shiner, Northern Squawfish and Longscale Sucker.

\section{Chapter 1.3 The Historical Perspective}

Before settlement, the most significant impacts on the Parkland landscape were wildfires, grazing and trampling by animals such as bison, and aboriginal activities such as hunting. The aboriginal peoples deliberately burned extensive portions of the land regularly to "improve" the Parkland for bison and other ungulates (Edwards 1970, p114; Finlay 1996, p11). Natural disturbances such as fires, floods and grazing were a normal part of the Parkland ecosystem and human impact on the Parkland landscape and its species may have been relatively small, although Geist (1996, p62) proposes that aboriginal peoples in North America kept numbers of some species reduced.

The Parkland was home to large numbers of grazing animals such as bison, Pronghorn and elk. Large predators such as wolves and grizzlies were common.

With the advent of the furtraders during the late 1700 s and early 1800 s, furbearers, large mammals and some birds (e.g., Trumpeter Swans) were heavily trapped and hunted (Finlay 1996, p11). One trading post in Alberta in the spring of 1798 reported that a party of plains Indians had "traded 3212 Swift Foxes, 940 wolves, 22 Red Foxes, 13 Badgers, 6 Wolverines and 4 Grizzly 
Bears" (ibid, p13). In 1812, the Hudson's Bay Company in Edmonton traded for 1296 swan skins and 450 hundred weight of swan quills (ibid.). Many of these birds came from Parkland habitats.

By the 1870s and 1880s, the bison had been hunted nearly to extinction, and numbers of elk and Pronghorn had declined (Coupland 1973). Near the turn of the century, Pronghorn numbers had dropped dramatically due to "increased fencing, agricultural development, improper stock grazing practices, drought, market-hunting, and illegal year-round hunting" (Mitchell 1980). The once common Plains Grizzly was all but gone from southern Alberta by the 1880 s, mainly due to overhunting. It was the first large carnivore extirpated from the Grassland and Parkland Natural Regions. The Gray Wolf was also extirpated a few years later (Willms and Dormaar 1996, p35). By the early 1900s, hunting had essentially "wiped out most of the accessible game to feed growing towns, mining camps, logging camps and other outposts. Elk survived only in a few small herds" (Van Tighem 1996, p6).

In the latter part of the 19th century, many prospectors, trappers, railroad builders, ranchers, settlers and adventurers were attracted to the Parkland (PrairiNet Webmaster 1996). Ranchers became established and livestock was brought in. Until the introduction of livestock, bison had been the most significant herbivore on the Parkland. Whereas bison were migratory and their use of areas somewhat irregular, cattle and sheep are comparatively sedentary and their effects more localized. The introduction of domestic livestock altered the Grassland and Parkland Natural Regions to "a grazing regime dictated by property ownership, fences, and the management skills of the individual rancher or farmer" (Adams et al. 1993, p126). The late 1800s were characterized by unrestricted year-round grazing, a situation that led to "substantial deterioration of many range areas" (ibid., p126, 131).

Around the turn of the century, another group of people came to the Great Plains - the homesteaders. These new settlers, called "sodbusters" by some, attempted intensive farming to raise cultivated crops rather than livestock. Significant cultivation of the Parkland began around the turn of the 20th century. In 1881, only 113,000 hectares on the plains of Canada were cultivated; by 1921, there were 16 million cultivated hectares (IISD 1994, p21). Between 1881 and 1901, the number of farms on the plains in Canada grew from 10,000 to over 55,000 (IISD 1994, p21). During the first 20 years of the 1900s, an additional 200,000 new farmers settled on the plains. As settlement spread, farmers brought increasingly more land into cultivation. Governments encouraged this through "policy that classified uncropped land as unimproved" (Van Tighem 1996, p7).

Our modern age has imposed "unprecedented stresses on grassland environments (note: including those of the Parkland). These could be considered damaging and irreversible" (Adams et al. 1993, p131). Since settlement, natural fires have been suppressed and flood regimes have been altered. Natural grazing patterns by free-roaming native ungulates have been affected. Within only a few decades, human settlement and the degradation or loss of natural disturbance regimes have had significant impacts on Parkland species, populations and ecosystems (Ostlie et al. 1996). Significant amounts of natural Parkland have been lost in Canada and Alberta. The extent of Parkland remaining is explored in the next chapter. 


\section{Chapter 1.4 Parkland Remaining}

The Canadian plains are among the most intensively developed landscapes in the world (Coupland 1973). If only arable land is considered, IISD (1994, p67) suggests that $81 \%$ (38 million hectares) has been cultivated. For the Parkland, estimates range from $85-95 \%$ for lands that have been lost through cultivation, roads, urbanization and other factors. Most of the native Parkland remaining is in the Central Parkland Subregion.

Coupland (1973) considers the grasslands found on the black chernozemic soils of Alberta and western Saskatchewan as fescue prairie. In the United States, this type of grassland is found only in the Montana foothills (ibid.). Coupland's fescue prairie is roughly analogous in Alberta to the Northern and Foothills Fescue Natural Subregions; it also includes the Central Parkland Subregion of the Alberta Natural Regions classification (Land Information Services 1994). Fescue prairie in Alberta forms part of the Great Plains Steppe ecological province of Ostlie et al. (1996, p24). Fescue prairie originally covered over 25.5 million hectares in the prairie provinces (Trottier 1992). By 1973, only two to four million hectares (five to 10 million acres) of natural fescue grassland remained (Coupland 1973). The amount remaining is generally quoted at $5 \%$ (Weins 1996) or less of the original area (Alberta Prairie Conservation Forum 1995, Diamond 1993, Trottier 1992). Fescue grasslands, including Parkland, are among the most threatened biogeographic regions on the Canadian plains because of extensive cultivation. Any remaining areas should be considered endangered. In Alberta, it is estimated that "more than $80 \%$ of the native prairie (note: including Parkland) landscape has been transformed by agriculture, industry and urbanization" (The Alberta Prairie Conservation Forum 1995). The area of uncultivated Parkland continues to decline.

The largest remaining blocks of Parkland in the world occur in Alberta: Rumsey and Sounding Lake-Wainwright (including Sounding-Sunken, Wainwright and Ribstone Creek blocks) in the Central Parkland, Peace River Valley in the Peace River Parkland and Highwood-Chaffen in the Foothills Parkland.

Woodlands on agricultural land in Alberta have decreased by $82 \%$ over a period of 55 years, from 1.56 million hectares in 1931 to 0.29 million hectares in 1986 (Weins 1996). The area in the Parkland and Grassland Natural Regions occupied by woodland decreased by at least $63 \%$ between 1971 and 1986 (Environment Canada 1991 in Diamond 1993, p180).

The three prairie provinces contain about $37 \%$ of Canada's wetlands (Weins 1996). In the Alberta Grassland and Parkland Natural Regions, there are an estimated 330,000 wetlands (Alberta Environmental Protection 1996a). They cover less than 5\% of the total land area in the region, since most are relatively small. Many are also seasonal since they dry out during the summer (ibid.). Although small in area, Parkland wetlands provide essential habitat for a number of plant and animal species, including several that are threatened or endangered. These include Piping Plover, Wandering Shrew, Northern Leopard Frog, and western blue flag (Westworth and Associates 1993b, p12-13). 
Historically, wetlands were often viewed as "wastelands", particularly in agricultural areas. There were more disincentives than incentives to preserve wetlands and wildlife habitat (IISD 1994, p71). As a result, wetlands were commonly drained and filled, and fields were cultivated from fence to fence. This practice "increased the total arable area and minimized the number of obstructions in fields" (Strong et al. 1993, p2). Since European settlement, wetland loss "has occurred throughout North America at an alarming rate and agriculture has been identified as the continuing major cause" (Usher and Scarth 1990, p5). In Canada, the modification of wetlands for agricultural purposes has accounted for $85 \%$ of total known changes (Cox 1993). In addition, transportation, utility, energy, and community developments, such as roads, pipelines, well-sites, or mines, have contributed directly or indirectly to the loss or degradation of wetlands (Alberta Water Resources Commission 1993a).

Extensive drainage of wetlands, including stream and river channelization, has occurred in many areas of the Parkland. This practice began in the late 1800s with settlement of the area and has been a major cause of wetland loss (Alberta Water Resources Commission 1993b). According to Usher and Scarth (1990, p5),

" . . A first drainage peak was experienced at the beginning of the century as prairies were converted to crop and forage production. Drainage activity declined during the drought of the 1930s, but accelerated again in the late 1940s. In the mid-1950s, with the advent of larger farm equipment, wetland drainage expanded to include wetlands more difficult to drain. This trend has continued to the present and now includes drainage of wetlands on marginal agricultural land..."

According to Strong et al. (1993, p138), wetland losses are continuing even though "agricultural expansion in southern Alberta may be relatively static." For example, between 1973 and 1983, a $24 \%$ loss of critical wetland habitat occurred in six irrigation districts in southern Alberta (Alberta Forestry, Lands and Wildlife, n.d.). This was due, in part, to improved irrigation practices such as restoration of canals to improve water movement efficiency and conservation. Historically, leaky canals and ditch irrigation often resulted in wetlands being created along their margins. These canals and ditches were a source of water during midsummer when other wetland basins were dry.

Although all figures do not agree, clearly the extent of change to wetlands has been considerable, as documented by the following:

\section{Canadian Prairies:}

- Environment Canada (1986a) as cited in Diamond (1993, p180) stated that "the number of prairie wetlands overall has declined by over $70 \%$ since European settlement."

- Over the last 200 years about 20 million hectares of Canadian wetlands have been converted to other uses. In Canada, almost $71 \%$ of wetland area has been lost (Westworth and Associates 1993b, p1). In comparison, approximately $79 \%$ of freshwater wetlands have been lost in the U.S. (Wetlands for the Americas, n.d.).

- Environment Canada (1994) estimated that agricultural practices influenced about $22 \%$ of the 
wetland basins in prairie Canada in 1994.

- IISD $(1994, \mathrm{p} 71)$ estimated that $50 \%$ of the original prairie wetlands have been converted to agricultural land.

- PHJV $(1993, \mathrm{p} 5)$ proposed that $40 \%$ to $70 \%$ of the original wetlands have been lost in the prairies to various causes.

- Turner and Pryor $(1992, \mathrm{p} 22)$ noted that for 1989 in prairie Canada, $75.2 \%$ of the wetland basins were degraded to some degree.

- IISD $(1994, \mathrm{p} 112)$ estimated that $40 \%$ of the original wetlands in the prairie region have been drained.

\section{Alberta's Parkland:}

- Strong et al. $(1993, \mathrm{p} 128)$ estimated that $63 \%$ of the original number of wetland basins that existed in the late 1800s in Alberta's White Area have been lost through agricultural and other landscape developments, at an annual attrition rate of about $1 \%$.

- The Alberta Prairie Conservation Forum (1995) stated that 1.2 million hectares of wetlands in the Grassland and Parkland Natural Regions of Alberta have been converted to agricultural use.

"The continuing loss and degradation of wetland habitats in the prairie-parkland region of Canada are serious problems, particularly when viewed in the context that $40 \%$ of the wetlands have already been lost" (Canada/US Steering Committee 1986 as cited in Turner and Caswell 1989). Parkland wetlands are vulnerable to ongoing impacts due to the "climate of the area, the less permanent nature of wetlands, particularly during drought, and the various land use activities in the region" (Strong et al. 1993, p133). Turner and Caswell (1989), as cited in Strong et al. (1993, p129), listed some of the impacts and the extent to which they occurred on wetland basins. These were: burning $(1.3 \%)$, haying $(4.9 \%)$, grazing $(22.4 \%)$, and cultivation $(34.9 \%)$.

Despite the already extensive losses, draining and degradation of wetlands continues. The rates are variously estimated as follows:

- $\operatorname{PHJV}(1993, \mathrm{p} 5)$ found that during one five-year period (1981-1985), $60 \%$ of the remaining wetland basins were impacted.

- Strong et al. $(1993, \mathrm{p} 127)$ reported that up to 2.4 wetland basins per square kilometre were lost between the 1970 and 1990 period due to human activity in Alberta's Grassland and Parkland Natural Regions.

- O'Leary and Downing (1990) found that the total wetland habitat in the EID of southern Alberta was reduced by 1234 hectares or by $7.6 \%$ between 1984 and 1987, an annual reduction of about $2.5 \%$.

- Brace and Pepper (1984) estimated that the drainage, filling and cultivation of wetlands in Alberta is occurring at a rate of about $13 \%$ per year.

Although the rate of wetland loss during the past few years may have slowed because of low grain prices, "drought conditions have allowed agricultural encroachment and greater margin impacts such as grazing" (Strong et al. 1993, p129). Bredy $(1995, \mathrm{p} 4)$ noted that intensive farming 
practices such as the cultivation and burning of wetland margins was in progress throughout his Alberta survey area in May of 1995.

Wetland margins are consistently altered by various impacts at a "higher rate than wetland basins" (Usher and Scarth 1990, p6), as shown by the following:

- Turner and Pryor (1992, p22) noted that for 1989 in the Grassland and Parkland Natural Regions of Canada, $92.2 \%$ of the wetland margins were degraded to some degree.

- Nelson (1989) reported that $88 \%$ of wetland margins in Grassland and Parkland Natural Regions of Canada had been impacted during the 1980 to 1987 period. He also estimated that of the 2.6 million wetlands in Grassland and Parkland Natural Regions of Canada that held water in 1987, intact margins surrounded fewer than 400,000 (15\%).

- Environment Canada (1994) estimated that agricultural practices have affected about $80 \%$ of wetland margins in Grassland and Parkland Natural Regions of Canada.

Turner and Caswell (1989), as cited in Strong et al. (1993, p129), listed some of the impacts and the extent to which they occurred on wetland margins. These were: burning $(0.9 \%)$, haying $(4.7 \%)$, grazing $(33.2 \%)$, and cultivation $(55.9 \%)$.

Cattle are attracted to wetlands and can contribute to their degradation. Grazing can eliminate food and cover plants, reduce nest-sites and overall habitat diversity. Cultivation of wetlands destroys the aquatic ecosystem and the plants, invertebrates and animals dependent on them (Ignatiuk and Duncan, 1995). The hardest hit wetlands are usually the shallow temporary ponds that are easily cultivated but are the preferred habitats for many species of ducks and other wildlife (ibid.).

The loss or degradation of wetlands through various agents destroys wildlife habitat and the staging and nesting areas for millions of migratory birds (Alberta Environmental Protection 1995; Alberta Water Resources Commission 1987, 1993a; Nietfeld et al. 1985). In addition, loss of wetlands results in reduced snow catchment and increased soil and water erosion (Ignatiuk and Duncan, 1995).

Drainage practices can be especially detrimental to nesting waterfowl (IISD 1994; Alberta Water Resources Commission 1987). This group of birds is "dependent not only on the wetland basins in an area but also on the quantity and quality of habitat surrounding the basins" (Turner and Pryor 1992, p113). From 1968 to 1991, there has been a general downward trend in the number of ponds present on the southern prairies during May (IISD 1994, p1 13). According to IISD, "the number of ponds occurring on the prairies in May is a factor of agricultural practices and weather patterns." May pond counts for 1992 were significantly lower than the long-term (i.e., 1961-1991) mean, partially due to the effects of El Nino (Turner and Pryor 1992, p18). "The coinciding population declines in May mallards indicates the relationship between May ponds and ducks" (ibid., p1 13). In 1985, the Grassland and Parkland Natural Regions experienced the lowest duck numbers in three decades, after years of drought and loss of habitat (NAWMP 1996). 
Today, wetlands are more widely accepted as valuable ecosystems important in maintaining ecological diversity, wildlife habitat, hydrologic balance and water quality (Westworth and Associates 1993b; Alberta Water Resources Commission 1993a, 1993b). Helped by several seasons of high precipitation, NAWMP and other organizations and agencies are making progress in securing habitat and restoring waterfowl populations. Survey estimates in 1996 show that there has been an increase of about 35 million ducks since 1985. This is good news, but, the destruction of wetlands, although reduced, continues (ihid.).

The next chapter examines the issue of fragmentation, focusing on transportation networks and petroleum and natural gas activity.

\section{Chapter 1.5 Fragmentation of Parkland by Linear Disturbances}

\subsubsection{What is fragmentation?}

Fragmentation is a process with recognizable phases that occurs over time as developments slowly change the nature of a landscape. Initially, natural habitat is extensive and contiguous. It makes up the majority of the landscape, or forms the matrix. Natural habitat remains predominant in the early stages of fragmentation and the fragments remain mostly connected to each other. As the area becomes more developed, the landscape becomes dissected into smaller and smaller parcels. Eventually, the developed landscape forms the matrix, and only scattered fragments of the original natural habitat remain. The once-continuous expanse of Parkland landscapes has been fragmented by roads, fences and hydroelectric lines, cultivation, towns and water reservoirs.

Most habitat fragmentation studies have looked at forest-dwelling birds. The studies generally conclude that there are "interior species," that rely on relatively large, undisturbed forest patches. Disturbances that cut through these patches introduce an "edge" into the once undisturbed area, bringing with it microclimatic changes, vegetational changes, species changes and increased predation and parasitism. Interior species tend to be "habitat specialists," the species that prefer edges are often "habitat generalists." As fragmentation proceeds, the patches become too small to support populations of interior species and edge species increase (Hobbs and Huenneka 1992). Recent studies have found that not only are birds affected by fragmentation, but also mammals (eg. Mills 1995; Stelfox 1995), invertebrates (eg. Webb 1988) and plants (eg. Jennersten 1988).

The interface between native grassland and tame pasture or hay fields is less dramatic than that between forest and clearing. This means that there is some question as to whether the effects of habitat fragmentation in prairies are comparable to those in forests. There are few studies that have looked at this question. Herkert (1994), in a three-year study of grassland fragments, found that fragment size "strongly influenced bird communities within grasslands." Larger fragments consistently had not only more breeding birds but also greater species richness. Some species were never found in smaller fragments, even when suitable habitat was present; some seemed more dependent on habitat type than fragment size, and some were clearly "edge" species (ibid.). Thus, as in forests, there are "area-sensitive" species in grasslands that require habitat of a 
minimum size. Burrowing owls, for example, are more likely to be found in larger pastures than on smaller ones (Ganes 1992). As fragmentation proceeds, these area-sensitive species would be predicted to be the ones showing the most serious population declines.

There is a point, termed a "critical threshold," at which the once-connected landscapes become disrupted. Once this point is reached, "small changes in the spatial patterning of resources can produce abrupt, sometimes dramatic ecological responses, with serious ecological consequences" (With and Crist 1995). Small changes in the composition of the landscape near the critical threshold are thus likely to have discernible effects on the distribution and persistence of populations. Persistence is a measure of whether a population dies out or maintains itself over the long term. The critical threshold is the "proportion of the landscape at which populations shift from random to clumped distributions" (ibid.). The switch occurs because the species no longer has an integrated landscape that it can move through, and populations concentrate in remaining suitable habitat.

The point that a critical threshold is reached for a species depends first on its degree of habitat specialization, that is, whether it can live in almost any type of habitat or if it is restricted to a single habitat type, like spiderworts are to open sand dunes. Based on computer simulation models done by With and Crist (1995), habitat specialists showed clumped distributions when $45 \%$ or less of the landscape was composed of their preferred habitat. Because they are so closely associated with a specific habitat, they were unlikely to leave once they encountered it (ibid.). When suitable habitat fell below $20 \%$ of the landscape, even species having low affinity to any particular habitat (habitat generalists), began to show clumped distribution. For habitat generalists, their ability to disperse seemed to have the greatest effect on the critical threshold, with small changes in dispersal ability greatly changing the critical threshold.

Whether a landscape has been fragmented beyond a critical threshold depends on the species being looked at, its degree of habitat specialization and its ability to move between habitat fragments. With and Crist (1995) summarize the threshold effect as follows, "Above this threshold, the primary effect of habitat fragmentation is loss of habitat with a concomitant decrease in species richness and population size. Below the threshold, habitat fragmentation increases isolation of habitat patches, thereby reducing landscape connectance."

Island biogeography theory has been used extensively to predict what happens when fragments have lost their connectance. As summarized in Alberta Environmental Protection (1996), as fragments become isolated, the likelihood of individuals moving between fragments decreases, heightening the risk that species will become extirpated from the individual fragment. The effects on biodiversity can be devastating. Smaller patches can support fewer individuals, and smaller populations are more susceptible to local extinction than larger populations. "Habitat alienation and fragmentation can reduce the viability of plant and animal populations by reducing population levels, genetic diversity and gene flow among isolated subpopulations" (Westworth \& Associates 1993a, pN-2). Both Tilman et al. (1994) and Wickett et al. (1992, p115) have found that the rate of species extinctions increases as remnant size decreases and those species that survive have less chance of surviving over the long term. Habitat fragmentation has become recognized as the 
most serious threat to biological diversity, a "problem of global proportions" (Wickett et al. 1992, p115; Wilcox and Murphy 1985).

\subsubsection{Are the Alberta Parklands Fragmented?}

According to Wickett et al. (1992, p115), "the most severe case [of fragmentation] has occurred on prairies even though all ecosystems have been impacted." Once there were continuous expanses of native parkland, in various states of disturbance because of native ungulate grazing and natural fires. That situation has changed, as described by Owens and Myres (1973, p710):

"...There [now] exists a patchwork made up of: (a) relatively undisturbed native prairies used as a source of wild hay, (b) grazed native prairie, (c) cultivated land with the native flora removed, (d) roadside ditches and field edges which often contain mixed exotic and native plant species, (e) land seeded to exotic grass species which may be used either as pastures or hay fields, and (f) areas where farm buildings and other structures have been erected often with windbreaks of native or introduced trees and shrubs..."

Native habitats now make up only "about 25\% of the prairie landscape" (Bradley and Wallis 1996). Clearly, the answer is yes, the Alberta parklands have become a fragmented landscape.

\subsubsection{Agents of Fragmentation}

Many agents can cause fragmentation of habitats. Some of these include cultivation, urban developments, etc. Rivers can be fragmented by the presence of dams as discussed by Trant et al. (1995) and Van Tighem (1989). Two additional major agents of fragmentation in the Parkland Natural Region are transportation networks and petroleum and natural gas exploration and development (e.g., wellsites and access roads). These are addressed in the following discussion.

\section{Transportation Networks}

"If I had to choose one indicator to assess and compare the ecological integrity of wildlands, it would be road density, as roads make most other human disturbances possible and have cumulative effects that persist as long as the roadbed is in place." Noss (1995)

The use of land for transportation corridors (e.g., highways, roads, railroads) in Alberta has increased at a rapid pace since early settlement. Alberta now has over $50,000 \mathrm{~km}$ of roads and railroads in the Parkland Natural Region (Table 3), and over $90,000 \mathrm{~km}$ if wellsite roads are included (Table 4). Increased transportation networks increase "the ease of access to remote or inaccessible areas containing sensitive ecosystems" (Environment Canada 1986a). "Roads can change the flow of water through compaction, loss of infiltration, and alteration of surface flow resulting in the interruption of hydrological regimes" (Monds 1995). In addition, habitat is lost when a road is constructed and remaining habitat becomes further fragmented. 
The Parkland Natural Region contains approximately 63,611 wellsites (Table 4), each reached by an access route. With an estimated average road length of $0.6 \mathrm{~km}$ per well (Horejsi 1995), there are about $38,166 \mathrm{~km}$ of access roads (Table 4). Using an average width of 15 meters for wellsite roads (ibid.), they have replaced an estimated $572 \mathrm{~km}^{2}(=6.2$ townships) of habitat in the Parkland Natural Region. This is likely a maximum figure since some roads to abandoned wellsites may have been reclaimed. Reclaimed roads, however, are unlikely to have been seeded with native species. They are often seeded to non-native species such as crested wheatgrass.

\begin{tabular}{|c|r|r|r|r|}
\hline Table 3. Linear distances (km) of roads and railways in the Parkland Natural Region. \\
\hline Type of Road & $\begin{array}{c}\text { Central } \\
\text { Parkland }\end{array}$ & $\begin{array}{c}\text { Foothills } \\
\text { Parkland }\end{array}$ & $\begin{array}{c}\text { Peace River } \\
\text { Parkland }\end{array}$ & Total \\
\hline Primary - paved & 2707 & 326 & 276 & 3308 \\
\hline Primary - divided & 594 & 54 & 5 & 653 \\
\hline Secondary - paved & 2582 & 217 & 182 & 2981 \\
\hline Secondary - gravel & 782 & 54 & 75 & 911 \\
\hline Improved & 26242 & 1130 & 2743 & 30114 \\
\hline Unimproved & 7542 & 824 & 411 & 8776 \\
\hline Truck trail & 2514 & 83 & 172 & 2770 \\
\hline Railway* & 2370 & 77 & 218 & 2665 \\
\hline "Highway" road length $\left(\mathrm{km}^{* *}\right.$ & 45333 & 2765 & 4082 & 52180 \\
\hline Area of Subregion $\left(\mathrm{km}^{2}\right)$ & 53413 & 4402 & 4665 & 62480 \\
\hline Road density $\left(\mathbf{k m}^{2} \mathbf{k m}^{2}\right)$ & $\mathbf{. 8 5}$ & $\mathbf{6 3}$ & $\mathbf{. 8 8}$ &. $\mathbf{8 4}$ \\
\hline $\begin{array}{l}\text { * Railways were included in all calculations of road lengths and road densities. } \\
\text { ** "Highway" refers to all of the road types, including railways, listed in this table. }\end{array}$ \\
\hline
\end{tabular}




\begin{tabular}{|c|c|c|c|c|}
\hline Factor & $\begin{array}{l}\text { Central } \\
\text { Parkland }\end{array}$ & $\begin{array}{l}\text { Foothills } \\
\text { Parkland }\end{array}$ & $\begin{array}{l}\text { Peace River } \\
\text { Parkland }\end{array}$ & Total \\
\hline Total no. wellsites & 60514 & 1167 & 1930 & 63611 \\
\hline Wellsite road length $(\mathrm{km})^{*}$ & 36308 & 700 & 1158 & 38166 \\
\hline Area of Subregion $\left(\mathrm{km}^{2}\right)$ & 53413 & 4402 & 4665 & 62480 \\
\hline Wellsite road density $\left(\mathrm{km} / \mathrm{km}^{2}\right)$ & .68 & .16 & .25 & .61 \\
\hline "Highway" road length $(\mathrm{km})^{* *}$ & 45333 & 2765 & 4082 & 52180 \\
\hline $\begin{array}{l}\text { Total road length }(\mathrm{km}) \\
\text { (Wellsite + Highway) }\end{array}$ & 81641 & 3465 & 5240 & 90346 \\
\hline $\begin{array}{c}\text { Overall road density }\left(\mathrm{km} / \mathrm{km}^{2}\right) \\
(\text { Wellsite }+ \text { Highway) }\end{array}$ & 1.53 & .79 & 1.12 & 1.45 \\
\hline \multicolumn{5}{|c|}{$\begin{array}{l}\text { NOTE: road area was calculated using an average width of } 15 \mathrm{~m} \text { for wellsite roads. } \\
* \text { Wellsite road lengths were calculated using an average road length of } 0.6 \mathrm{~km} \text { per wellsite } \\
\text { (Horejsi (1995). } \\
\text { ** Highway road lengths taken from Table } 3 \text {. }\end{array}$} \\
\hline
\end{tabular}

When wellsite roads are considered, there is an overall road density of approximately $1.45 \mathrm{~km}$ of road for each square kilometre of land in the Parkland Natural Region (Table 4). Without wellsite roads, the road density drops to $0.61 \mathrm{~km} / \mathrm{km}^{2}$ (Table 4). The Central Parkland Subregion has the highest road densities in the Parkland Natural Region $\left(1.53 \mathrm{~km} / \mathrm{km}^{2}\right.$ when wellsite roads are included or .68 if wellsite roads are not included -- see Table 4). With wellsite roads included, the Foothills Parkland and Peace River Parkland Subregions have the lowest road densities, at 0.79 and $1.12 \mathrm{~km} / \mathrm{km}^{2}$ respectively (Table 4). By comparison, in a study of linear disturbances in the Eastern Slopes, an overall road density of $0.40 \mathrm{~km} / \mathrm{km}^{2}$ was found (Alberta Environmental Protection 1996). Although high, little work has been done on the effects of road densities on Parkland ecosystems.

Roads and their rights-of-way occupy an area equivalent to 13.3 townships of land in the Parkland Natural Region and nearly 20 townships if wellsite roads are included (Table 5). This figure does not include the road networks in towns and cities. The Central Parkland Subregion, at 2.0\%, and Peace River Parkland Subregion, at $2.4 \%$, have the highest proportions occupied by roads, if wellsite roads are included in the calculations (Table 5). This Subregion has a significant level of major roads, including stretches of Highways 2 and 16. 


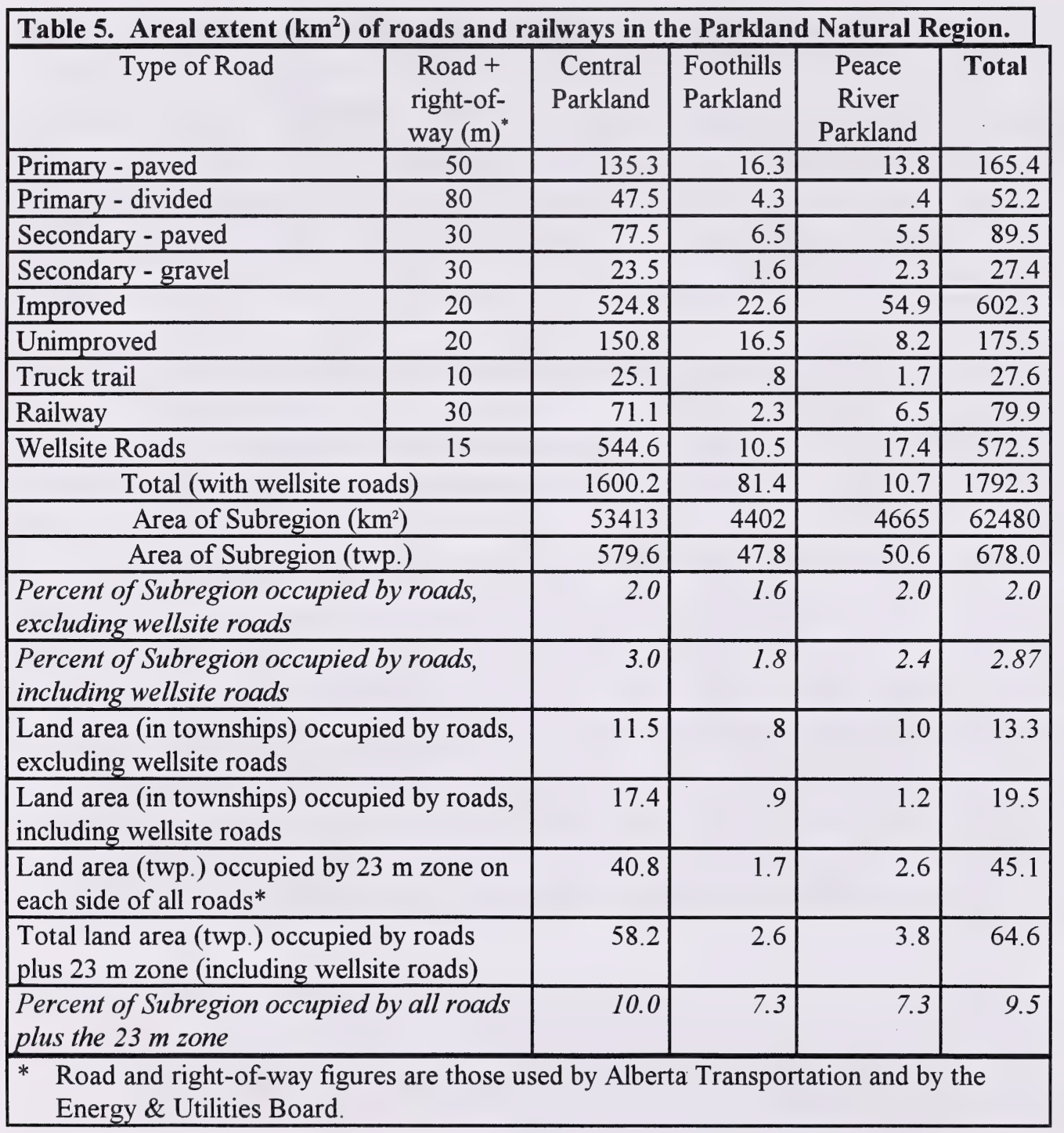


When development occurs, an edge is created. This has associated edge effects that influence the native habitat beyond the actual development itself. Edge effects have not been well studied in Parkland ecosystems. One study, however, found "alien" or exotic plant species in a $23 \mathrm{~m}$ wide zone on either side of the road right-of-way (Christiansen 1990, p127). If this is the case for the Alberta Parkland Natural Region, then an additional area equivalent to 45 townships (Table 5) would have reduced habitat quality due to edge effects alone.

If all roads plus the $23 \mathrm{~m}$ zone of influence on either side are considered, an area equivalent to 65 townships of land, or $9.5 \%$, of the Parkland Natural Region has been affected (Table 5). Of the three Subregions, the highest proportion occupied by roads (including wellsite roads) and the associated $23 \mathrm{~m}$ zone of influence is $10 \%$ (Table 5) in the Central Parkland Subregion.

Within the Parkland Natural Region, few extensive areas remain roadless (Map B, back of document). Natural habitat is lost and the potential for invasion by exotic species is increased with increasing "roading". This reduces their ecological integrity and value for protected areas.

\section{Petroleum and Natural Gas Activities}

Of all the energy produced in Canada in 1995, about 70\% comes from Alberta (Alberta Energy and Utilities Board 1996). The province has just over $60 \%$ of the country's conventional oil reserves and $83 \%$ of the natural gas reserves. Development and production of reserves can take many years and involves the construction of wells, roads and facilities. "Once a field has been established, environmental disruptions become extensive, cumulative, often long term, and would occur continually in varying degrees because of the need for recurring human activity" (Bromley 1985). In a letter addressed to all oil, gas and pipeline operators in the province, the ERCB stressed the need for "an increased awareness by industry, government, and the public that native prairie grassland is a rapidly disappearing ecosystem, and that the cumulative long-term impact of all development, including oil and natural gas, can be very significant" (National Energy Board 1996, p31).

Some cumulative impacts include: soil compaction, stripping and mixing of soil, increased erosion, increased weed invasion, provision of access into once inaccessible areas, the construction of roads, wellsites, pipelines and production facilities, accidental spills (crude oil, drilling fluids, salt water, natural gas), hydrogen sulphide emissions and other pollutants, and the accumulation of debris and wastes from construction and drilling activities (ERCB 1992; National Energy Board 1996). Fuel spills are especially destructive. "The imprint on the land from many of these activities is usually permanent" (ERCB 1992, p1-2).

Wildlife and their habitats have been affected by activities associated with the petroleum industry. There is often considerable fragmentation and loss of native habitat. The severity is "site-specific and depends on the sensitivity of the species affected, the nature of the environmental disruption, habitat characteristics, the availability and condition of alternative habitat," and other factors (Bromley 1985). For example, Pronghorn and other animals tend to be temporarily or permanently displaced from areas of active drilling, pipeline construction and well maintenance 
(Bromley 1985; Easterly and Guenzel 1992; National Energy Board 1996). Flare stacks have been implicated in causing mortality to some bird species (Bjorge 1987) and toxic pits have caused wildlife deaths (e.g., coating of waterfowl with oil). Hunting pressure on wildlife populations may increase due to increased access (Bromley 1985).

Since keeping of well records started in 1902, approximately 167,000 gas and oil wells have been drilled in Alberta (Alberta Energy and Utilities Board 1996).

According to Kerr et al. (1993), nearly 110,000 oil and gas well sites have been constructed. The 1996 digital files of the Alberta Energy and Utilities Board, however, show fewer wellsites.

Nearly 75,000 (about $45 \%$ of the total for Alberta) have been drilled within the Parkland Natural Region (Table 7). This equates to a wellsite density of 0.77 wellsites $/ \mathrm{km}^{2}$ or one wellsite/1.29 $\mathrm{km}^{2}$. Wellsite locations are plotted on Map B (back of document) and wellsite densities graphically depicted in Figure 6. If an average lease size is 1.4 hectares (Horejsi 1995), then with 74,629 wellsites, a cumulative land area of about $1045 \mathrm{~km}^{2}$ (=11.2 townships) has been directly affected by this activity.

\begin{tabular}{|l|r|r|r|r|}
\hline \multicolumn{6}{|c|}{ Table 6. Wellsites in the Parkland Natural Region. } \\
\hline Wellsites & $\begin{array}{c}\text { Central } \\
\text { Parkland } \\
\text { Subregion }\end{array}$ & $\begin{array}{c}\text { Foothills } \\
\text { Parkland } \\
\text { Subregion }\end{array}$ & $\begin{array}{c}\text { Peace River } \\
\text { Parkland } \\
\text { Subregion }\end{array}$ & Total \\
\hline total no. wellsites & 60514 & 1167 & 1930 & 63611 \\
\hline $\begin{array}{l}\text { area of Subregion } \\
\left(\mathrm{km}^{2}\right)\end{array}$ & 53413 & 4402 & 4665 & 62480 \\
\hline${\text { wellsites/ } / \mathrm{km}^{2}}^{2}$ & 1.1 & .3 & .4 & 1.0 \\
\hline $\mathrm{km}^{2} /$ wellsite & .9 & 3.8 & 2.4 & 1.0 \\
\hline $\begin{array}{l}\text { mean no. } \\
\text { wellsites/twp. }\end{array}$ & 104.1 & 24.9 & 37.8 & 94.0 \\
\hline
\end{tabular}

The Parkland Natural Region wholly or partially overlies scores of natural gas and oil fields (Energy Resources Conservation Board, 1994). For a given reservoir, the well densities normally permitted in Alberta are one per square mile $\left(2.59 \mathrm{~km}^{2}\right)$ for gas and 16 per square mile for oil (i.e., one per $0.16 \mathrm{~km}^{2}$ ). In exceptional circumstances oil well densities may be as high as four per legal subdivision (i.e., one per $0.04 \mathrm{~km}^{2}$ ). The difference in oil and gas well spacing has important implications for the intensity of environmental impacts from oil versus gas exploration, drilling and production. To process the production from these fields, there are at least 51 natural gas processing plants within this region with a capacity of over 0.5 million cubic metres per day (ibid.).

Wellsite densities for the Parkland Natural Region are high relative to the other natural regions. For example, the Foothills Natural Region has wellsite densities of 0.28 wellsites $/ \mathrm{km}^{2}$ or one wellsite $/ 3.52 \mathrm{~km}^{2}$ (Alberta Environmental Protection 1996, p17). This is less than one-third the density of wellsites found in the Parkland Natural Region (1.1 wellsites $/ \mathrm{km}^{2}-$ Table 6$)$. On crown 
land in the Central Parkland Subregion, the density of well sites rises to 1.6 wellsites $/ \mathrm{km}^{2}$ on O/C Natural Areas and 1.3 wellsites $/ \mathrm{km}^{2}$ on PNTs (protective notations). This trend to higher densities of well sites on O/C Natural Areas and PNTs is also evident in some other Natural Regions, e.g in the Lower Foothills there are 1.04 wellsites $/ \mathrm{km}^{2}$ on O/C Natural Areas and .7 wellsites $/ \mathrm{km}^{2}$ on PNTs (protective notations) compared with .3 wellsites $/ \mathrm{km}^{2}$ as an average on all crown land.

Townships with the highest wellsite densities are more fragmented than those in the lower density classes. Natural habitat is lost and the potential for invasion by exotic species is increased. This reduces their ecological integrity and value for protected areas.

There are also pipelines and associated access routes throughout much of Alberta. During 1995, for example, construction permits were approved for $10,590 \mathrm{~km}$ of pipelines. This is down $25 \%$ from the record level of $14,300 \mathrm{~km}$ of pipeline constructed in 1994. The total length of pipelines in Alberta was 250,498 km at the end of 1995 (Alberta Energy and Utilities Board 1996). Using an average width of 15 meters for pipeline rights-of-way (Horejsi 1995), they have impacted an estimated $3757 \mathrm{~km}^{2}$ (40.3 townships) of land in the province. For the recently-constructed Express Pipeline from Hardisty to Wildhorse, it was estimated that 717 ha (nearly $3 \mathrm{mi}^{2}$ ) of uncultivated land would be disturbed (National Energy Board 1996, p31).

Construction of pipelines has influenced Alberta's Parkland in several ways. Total plant cover is generally less and species composition is different on pipeline rights-of-way than on adjacent undisturbed areas (Hardy and Associates Ltd. 1975). Also, plant cover can be very patchy, perhaps due to the mixing of surface and subsurface soils during the construction phase of the pipeline (ibid.). Pipeline rights-of-way typically support many weedy species (e.g., thistle, foxtail barley, knotweed) and often have been seeded with exotic species (e.g., crested wheat grass, smooth brome). Native grasses are generally poorly represented since invasion of native species onto the rights-of-way in native Parkland appears to be a slow process. AWA and FAN stated in a submission by to the Express Pipeline Project Hearing that "after five years or even 25 or 50 years, there still may not be the mix of species which was present before construction" (National Energy Board 1996, p38).

In addition, "animal burrows are frequently concentrated in the berms" of the pipeline route (Hardy and Associates Ltd. 1975). Cattle frequently amplify the pipeline disturbance by concentrating trails, bedding and grazing on the rights-of-way. They often preferentially graze seeded rights-of-way over native pastures. According to the National Energy Board (1996, p49), "long-term sedimentation problems [in rivers] can also occur after pipeline construction where right-of-way preparation has removed stabilizing vegetative structures."

Many species used in the seed mixtures for reclamation of pipelines are invasive. Smooth brome, for example, is "an aggressive invader of prairie dominated by plains rough fescue" (Grilz and Romo 1995). As discussed earlier, non-native species have been shown to invade into the native grassland up to $23 \mathrm{~m}$ from a disturbance edge (Christiansen 1990). If a $23 \mathrm{~m}$ zone of disturbance was added to both sides of the pipeline rights-of-way, this would significantly increase the land 
area impacted by pipelines in the Parkland.

The fragmentation, degradation and loss of natural Parkland habitat, including upland woodlands, grasslands and wetlands, has had significant impacts on the plant and animal species that depend on those habitats. Several Parkland species are now considered at risk in Canada, as determined by the Committee on the Status of Endangered Wildlife in Canada (COSEWIC), and other agencies and organizations. The next chapter focuses on these at risk species.

\section{Chapter 1.6 Parkland Species at Risk}

There are a number of Parkland species at risk. Species are considered endangered or threatened (e.g., Burrowing Owl, Piping Plover); others have been extirpated (e.g. Greater Prairie Chicken) (COSEWIC 1996; IISD 1994, p71). The historical distribution and dispersal patterns of some species have been altered.

Within the Great Plains area of North America, 464 species of concern (212 animals, 234 plants) have been identified. This includes species considered: critically imperiled (117); imperiled (123) or rare (224) globally. Of those 464 species, 327 or $70.5 \%$ are either endemic or nearly endemic to the region (Ostlie et al. 1996, pg. viii). This means that "the existence of those species depends on their survival within the Plains, not somewhere else in the world" (ibid.). In addition, fully $42 \%$ of the endemic or near-endemic plant community types are critically imperiled $(6 \%)$, imperiled $(20 \%)$ or vulnerable $(16 \%)$.

Of 324 vascular species considered rare in Canada, about $25 \%$ are Grassland and Parkland Natural Region species (Bradley and Wallis 1996, p15). Many rare or threatened Parkland species are found only in special habitats such as sand dunes or alkali wetlands. In Alberta, about $20 \%$ of the rare plants in the Grassland and Parkland Natural Regions are found in sandy soils, principally in sand hill areas (Wallis 1987).

This and the next chapter reviews the listing of species by the Committee on the Status of Endangered Wildlife in Canada, the Status of Alberta Wildlife document and the Alberta Natural Heritage Information Centre.

\subsubsection{COSEWIC Listings of Species at Risk in Canada}

The Committee on the Status of Endangered Wildlife in Canada reviews and ranks species at risk into different risk categories, as follows:

Extinct:

Extirpated: Endangered:

Threatened:

Vulnerable: a species that no longer exists.

a species no longer existing in the wild in Canada, but occurring elsewhere. a species facing imminent extirpation or extinction. a species likely to become endangered if limiting factors are not reversed. a species of special concern because of characteristics that make it particularly sensitive to human activities or natural events. 
COSEWIC reviews species for potential ranking only after a status report has been completed. There are many species, particularly plants and invertebrates, for which status reports have not yet been done. Many of these species could potentially be listed. To date, COSEWIC (1996) has ranked 272 animal and plant species at risk in Canada. Thirty-nine (14.3\%) of them occur or were formerly present within the Grassland and Parkland Natural Regions of Alberta, Saskatchewan and Manitoba. One hundred and fifty (55\%) species are in the extinct, extirpated, endangered and threatened categories. Of those, 18 (12\%) occur within the Grassland and Parkland Natural Regions.

About $77 \%$, or 24 of the 31 species at risk in Alberta, rely on Grassland and Parkland Natural Region habitats. In Saskatchewan that figure is 83\% (Table 7). According to Diamond (1993, p183), "prairie species can be described as nearly four times more likely than the national average to be at risk." At least one-third of the mammals and birds listed as endangered, threatened, or vulnerable by COSEWIC are associated with native Grassland and Parkland Natural Region habitats (World Wildlife Fund 1992). "Species now at risk are threatened most often by loss of habitat, so the current status of species of concern is usually an indicator of the availability of suitable habitat" (Diamond 1993, p181).

\begin{tabular}{|c|l|}
\hline Table 7. Parkland species at risk (COSEWIC 1997) \\
$\begin{array}{c}\text { Risk } \\
\text { category }\end{array}$ & \\
\hline Extinct & Passenger Pigeon (was in Alberta but no nesting records) \\
\hline Extirpated & Grizzly Bear - Grassland and Parkland Natural Region population \\
\cline { 2 - 2 } & Greater Prairie Chicken \\
\hline \multirow{5}{*}{ Endangered } & Burrowing Owl \\
\cline { 2 - 2 } & Peregrine Falcon \\
\cline { 2 - 2 } & Piping Plover \\
\cline { 2 - 2 } & Whooping Crane \\
\hline \multirow{5}{*}{ Threatened } & Loggerhead Shrike - Grassland and Parkland Natural Region population \\
\cline { 2 - 2 } & Western blue flag \\
\hline \multirow{2}{*}{ Vulnerable } & Ferruginous Hawk \\
\cline { 2 - 2 } & Short-eared Owl \\
\hline
\end{tabular}

The following discussion focuses on those COSEWIC-ranked species at risk that were or are currently found on the Canadian prairies.

\section{Passenger Pigeon (Extinct)}

The extinction of the Passenger Pigeon is one of the best known examples of human-caused loss of a species. Once one of the most numerous birds in North America, it came under excessive pressure with the growth of cities, the clearing of deciduous forests by European settlers and over-hunting in the 19th century. In 1851, for example, "nearly two million pigeons were shipped to market by rail from a single site in New York State" (Burnett et al. 1989, p10). 
The three to five billion Passenger Pigeons that lived in the forests and grasslands of Canada and the northern U.S. were decimated within decades. By the 1890 s these birds were rare. "No one did anything until it was too late and, in 1914, the last Passenger Pigeon died in a Cincinnati zoo" (Burnett et al. 1989, p10).

\section{Grizzly Bear - prairie population (extirpated)}

Grizzly Bear were abundant in the prairie region of Alberta during the 1700s, "especially along rivers that had suitable foods including berries, roots, carcasses of drowned bison and an abundance of other prey species" (Nagy and Gunson 1990, p2). Grizzlies once occurred on the prairies as far east as the Red River valley in Manitoba. During the 1800 s, explorers and fur traders shot grizzlies for safety reasons, for sport and for the money their pelts would bring. The species was still abundant in areas of southern Alberta in the 1850 s.

The beginnings of settlement, ranching and farming during the 1870 s spelled the end of the Grizzly Bear on the prairies. By the 1880 s they were all but gone from that part of Alberta. Sightings in southern Alberta east of the Rockies were considered abnormal by the 1890s. "By the $1950 \mathrm{~s}$, their range had receded to about three-quarters of that occupied during the pre- 1900 times" (ibid., p8). In 1991, the prairie population of the grizzly was added by COSEWIC to the list of species extirpated in Canada. In Alberta, the Grizzly Bear still occurs in the mountains, foothills and boreal forest and populations in these areas are considered "relatively stable outside the national parks since 1980" (AEP 1996, p21).

\section{Greater Prairie Chicken (extirpated)}

The Greater Prairie Chicken is not known to have existed in Canada before European settlement (Hjertaas et al. 1993). In the United States, this species inhabited extensive natural grasslands that were open to bushy. It also used lightly grazed grasslands located near bushy natural grasslands (Microsoft Internet Explorer 1996). The controlled fires, removal of Plains Bison herds and expanded food supply (e.g., waste grain) that came with settlement created suitable habitat for the Greater Prairie Chicken. This is thought to have resulted in the species expanding its range into Canada from Minnesota and North Dakota (Johnston and Smoliak 1976, p153).

Between the 1890s and the mid-1920s, the Greater Prairie Chicken "reached a population density [in the western prairies] estimated at over a million" (ibid., p154). Up to the mid-1920s, it was not uncommon in southern and central Alberta, but by the late 1930s, it had essentially disappeared from Canada. Among the reasons for its decline were the conversion of grassland to cropland, heavy cattle grazing, drought, harsh winters, increased hunting pressure and competition from pheasants (McNicholl 1988; Trottier 1992; Salt and Salt 1976, p111). The species is now essentially confined to the north-central United States (Salt and Salt 1976, p111). It has vanished from Ontario, Manitoba and Alberta, but there were about 15 sightings in Saskatchewan between 1965 and 1977 (Microsoft Internet Explorer 1996). It is considered extirpated from Canada, although the sightings from Saskatchewan suggest that some individuals may still be found, possibly during migration. 


\section{Burrowing Owl (endangered)}

COSEWIC (1996) lists the Burrowing Owl as an endangered species in Canada. It is unique among raptors in Canada for its habit of nesting in burrows. It relies almost entirely on the excavations of burrowing animals for this purpose. A pair of owls may use the same nesting area, and often the same burrow, year after year (RENEW 1996, p6). Thus, the availability of burrows and the presence of burrowing mammals are critical components of its habitat. This owl prefers open land with short vegetation in which to nest, with tall grassland nearby for hunting mice, voles, insects and other prey. Habitat size may also be important. A five-year study of Burrowing Owls in Saskatchewan found that "larger pastures contain more breeding pairs" than smaller ones. Populations on smaller pastures were also found to be more likely to become extirpated, possibly due to increased predation levels (James 1993).

From 1890 to the mid-twentieth century, the Burrowing Owl seems to have been common in some districts of the prairies, but uncommon or scarce overall. "The breeding population is historically sparse; increasing during the early to mid-1900s when mixed farming was prevalent, and declining with the intensification of agriculture" (Poston et al. 1990, p.90). A substantial decline in the population has occurred since the 1950s. This decline has been linked to the fragmentation and loss of prairie habitat, reduced prey due to pesticide use (e.g., Carbofuran an insecticide used for grasshopper control) and predation (AFGA 1993, pl; RENEW 1996, p6). "The loss, fragmentation and general degradation of nesting habitat is believed to be the single most important factor influencing the number of owls that nest in Canada" (Scobie 1994, p1). Also implicated is "control of burrowing mammals that provide nesting habitat" (Poston et al. 1990, p.90). Road kills, shooting, secondary poisoning and predation are additional factors (ibid.).

The Burrowing Owl population on the prairies is scattered over a large area of southern Alberta, Saskatchewan and Manitoba. Most of the owls are in Alberta and Saskatchewan (RENEW 1996, p7). The extent of the breeding range of Burrowing Owls in Canada is diminishing (AFGA 1993, p2), and the numbers of these owls continue to decline despite the efforts of a multi-agency recovery team (Hjertaas et al. 1995; Holroyd et al. 1993). In Manitoba, for example, from 76 known pairs in 1982, the population dropped to 8 pairs in 1994 (Hjertaas 1996). The estimated total number of breeding pairs in Canada is now between 1015 and 1695, an historically low number. AEP (1996, p19) concludes that the "population [is] declining dramatically in prairie habitats across Canada." In Alberta, the Burrowing Owl is on its RED LIST and is considered to be an "endangered animal" (AEP 1996, p19). The Alberta population is estimated at "700 to 900 breeding pairs (1995) and declining" (ibid.).

\section{Peregrine Falcon (endangered)}

The anatum subspecies of the peregrine inhabits the area south of the tree-line. "In the 1950's and 1960's, this subspecies underwent a significant decline" (Poston et al. 1990, p82). In Alberta, in the mid-1970s, less than 5 of 73 historical nest sites were occupied (Court et al. 1996). The decline has been linked to a reduced reproductive rate caused by ingesting prey contaminated by DDT and other organochlorines. "With restrictions on the use of DDT in Canada and the United 
States, combined with intense captive-breeding and release efforts, core populations of peregrine are now being naturally sustained or increased in all areas where the species was historically found" (RENEW 1996, p10). The Peregrine Falcon remains on the RED LIST for Alberta, as an "endangered animal" with less than 50 breeding pairs (AEP 1996, p19). "Continued provincial recovery of this species will depend on declining pesticide levels in prey, releases of captivereared chicks into southern Alberta and protection of wetland feeding areas" (ibid., p19).

\section{Piping Plover (endangered)}

This small plover depends on undisturbed natural shorelines to nest and raise it's young (Alberta Forestry, Lands and Wildlife 1990). "Pebble beaches and mudflats exposed by the receding waterlines of prairie sloughs and lakes is the critical habitat for this species. Availability of this habitat is variable from year to year depending on rainfall, so it is often difficult to predict just where birds will be found nesting" (Trottier 1992, p28). "Because this plover rests, feeds and raises young on the open beach flats, it is very vulnerable to disturbance from recreational activity, livestock trampling, and water-level stabilization projects that permanently flood shoreline habitat" (ibid., p28). Its habitat preferences also make it vulnerable to predators (RENEW 1996, p11).

Over much of their geographic range, Piping Plovers are in direct competition with people for open sand or pebble beaches, particularly in June and July when young birds are active. Human activities such as driving motorized vehicles on beaches used by the birds can result in nest abandonment or destruction. Agricultural development (e.g., drainage, cultivation) around lakes and sloughs has reduced the amount of suitable habitat available for nesting plovers. Changes to water levels such as those associated with lake stabilization projects are detrimental to this species (Microsoft Internet Explorer 1996), since high water levels can eliminate nesting habitat. At some beaches, cattle have trampled nests or young birds. Chicks may have difficulty climbing out of the deep holes left by livestock along lake shores (Alberta Forestry, Lands and Wildlife 1990).

The numbers of Piping Plovers have been decreasing throughout their range (Microsoft Internet Explorer 1996). This species is currently designated under the Alberta Wildlife Act and listed by COSEWIC as an endangered species. It is "threatened or endangered throughout North America" (AEP 1996, p19). In 1991, the entire prairie population of plovers was estimated at 1437 birds (RENEW 1996, p11). It occurs rarely and locally within Alberta. During a survey in 1986 , researchers recorded "approximately 100 breeding pairs and 88 non-breeding birds at 28 different sites" in Alberta (Alberta Forestry, Lands and Wildlife 1990). "Most of the breeding birds were found near Provost, Hanna and Medicine Hat" (ibid.). There are now an estimated 100 to 150 breeding pairs in Alberta (AEP 1996). Breeding pairs are often clustered in suitable lake shore habitat. Patriquin (1993, p29) lists this species and the Baird's Sparrow as the two top priority bird species of the prairie biome. "Recovery requires protection from human disturbance and management of key shoreline nesting habitats" (AEP 1996, p19).

\section{Whooping Crane (endangered)}

The Whooping Crane once ranged over a large part of western North America with the main nesting area in the Parkland (Godfrey 1966). The parkland population has been extirpated. Loss 
of habitat and over-hunting contributed to a precipitous decline to a low of 21 birds in 1941. Due largely to a concerted conservation effort that includes fostering of eggs and captive breeding, the wild population had increased to 146 by 1989 (Semenchuk 1992). Breeding in large, open, marshy areas, the Whooping Crane now nests only in Wood Buffalo National Park and winters in Texas.

\section{Loggerhead Shrike (threatened)}

The eastern population of this species is considered endangered; the prairie population is considered threatened (COSEWIC 1996). This species prefers open, short-cropped grassland habitats "for finding and capturing its principal prey of large insects, mice and even small songbirds. Shrub thickets are also essential for perching and nesting" (Trottier 1992).

Several shrike species have been declining in numbers in both North America and Eurasia (RENEW 1996, p9). In eastern North America, in states "such as New York, Pennsylvania and Virginia, populations have either disappeared or been reduced to mere scattered pairs" (Avian Science and Conservation Centre 1996). In Canada, there have been serious declines in the numbers of shrikes on breeding grounds (Johns et al. 1994). Prairie populations, however, appear to have stabilized in all areas except southwest Manitoba, where numbers continue to decline (Scobie 1994, p1; RENEW 1996, p9).

Declines in Loggerhead Shrike numbers are believed to be due primarily to loss of habitat on both wintering and breeding areas. This, coupled with the use of fertilizers and pesticides, has resulted in a diminished diversity and availability of prey (ibid.). The Loggerhead Shrike is on the YeLLow A LIST for Alberta. These are species "for which there has been concern expressed over long term declines in their numbers" (AEP 1996, p9). The "population is low, poorly understood and probably has declined in recent years" (ibid., p23).

\section{Western blue flag - Iris missouriensis (threatened)}

The following is taken from Wallis (1989). Western blue flag occurs "from southwestern Alberta, Washington, Idaho and Montana east to North Dakota and Minnesota and south through Nebraska, South Dakota, Wyoming, Colorado, Oregon, Nevada and Utah to southern California, Arizona, New Mexico and Coahuila in northern Mexico" (p4). "In Canada, western blue flag naturally occurs only in small populations in the extreme southwestern corner of Alberta so it is considered rare from a national perspective." (p2). Populations are known at Whiskey Gap, Carway, Mary Lake and Police Outpost Provincial Park. Surveys conducted in 1987 and 1989 show a total Alberta population of less than 7500 stems at six different sites.

"While it is abundant in portions of the Rocky Mountain states, there are large areas of its range where it is very localized. Its moist meadow habitats have been referred to as threatened or endangered ... The western blue flag's native foothills grassland habitats in Alberta have suffered considerable modification after European settlement and they continue to be converted to nonnative species" (p2). The "main limiting factors for this species are its natural narrow environmental tolerance and loss of natural habitat. It occupies a very narrow habitat niche between dry uplands and permanent wetlands" (p9). 


\section{Ferruginous Hawk (vulnerable)}

This species now inhabits about $48 \%$ of its former range (Microsoft Internet Explorer 1996). In the early 1900s, it nested throughout south and central Alberta, as far north as Edmonton. By 1987, nesting birds were found no further north than Coronation. "Ferruginous Hawks have retracted their range in Alberta about 40\%" (Schmutz et al. 1994, p17) and populations declined more than $50 \%$ where the land had been cultivated (Schmutz 1990).

This species is a specialized hunter of Pocket Gophers, ground squirrels and hares. "Ferruginous Hawks require uncultivated, open grassland with abundant ground squirrels, which comprise $80 \%$ of their diet" (RENEW 1996, p7). Without sufficient food, the hawks will not establish a nest. Loss of prairie habitat to cultivation, settlement and resource exploration has reduced prey abundance and availability of nesting sites. Fire suppression has allowed invasion by woody plants, further reducing prey habitat. This species is easily disturbed by human activity, particularly during the nesting period. These factors have led to serious declines in numbers of Ferruginous Hawks (Schmutz 1987; Trottier 1992, p19).

However, this species represents a minor recovery success story (RENEW 1996, p7).

Populations in southeastern Alberta are estimated to have increased from 1082 pairs in 1982 to 1772 pairs in 1987 (Poston et al. 1990). AEP (1996) estimates a current population of 1400 to 1700 pairs, over half the Canadian population (Microsoft Internet Explorer 1996). This increase is, in part, due to successful nest site restoration programs (e.g., protection of nest trees and erection of nesting platforms). Another important factor has been the cooperation of landowners who are increasingly aware of the essential role these predators play in the prairie ecosystem. The Ferruginous Hawk was listed as a species at risk (RED LIST) in 1991, but based on its population recovery, has been moved to the BLUE LIST (may be at risk). "If [the] current recovery of [the] breeding population continues and key nesting and feeding habitats can be secured, the species can be considered for change to a YELLOw LIST" (AEP 1996, p20).

\section{Short-eared Owl (vulnerable)}

This owl prefers to breed in relatively open country such as grassland, grassy or bushy meadows, marshland, pastures, stubble fields, crop lands, and previously forested areas that have been cleared. A combination of areas of suitable cover, with adjacent hunting areas containing an abundance of small mammals, is a dominant factor in selecting breeding habitat. It "relies on maintenance of edges of larger wetland habitats" (AEP 1996, p21).

This owl breeds in the south and central parts of the province (Semenchuk 1992, p155). The northern limit of breeding is at Peace River, Lesser Slave Lake, and Cold Lake (ibid.). Currently, it is a fairly common species in the Grassland and Parkland Natural Regions of the province (ibid.), but the "irruptive nature of populations make population trend assessments extremely difficult" (AEP 1996, p21). This owl was on the Audubon Society's Blue List of declining species from 1976 to 1986 (Semenchuk 1992, p155) and is now listed by COSEWIC as a vulnerable species (COSEWIC 1996). It is on the Alberta BLUE LIST as a species that may be at risk, but the "causes of population decline are unknown" (AEP 1996, p21). 


\section{Chapter 1.7 Notable Parkland Species and Species Groups}

The Alberta Parkland provides essential habitat for many species. The following section focuses on those species groups for which the Parkland is particularly important, such as migrating shorebirds and both nesting and staging waterfowl. Alberta Environmental Protection (1996b) groups Alberta's mammal, bird, amphibian and reptile species into four categories, as follows:

RED-LISTED species: Current knowledge suggests that these species are at risk. Populations of these species have declined, or are believed to have declined, to nonviable levels, or show a rate of decrease indicating that they are at immediate risk of declining to nonviable levels in Alberta.

BLUE-LISTED species: Current knowledge suggests that these species may be at risk. They are particularly vulnerable because of non-cyclical declines in population or habitat, or reductions in provincial distribution.

YELLOW-LISTED species: These are sensitive species that are not currently believed to be at risk, but may require special management to address concerns related to naturally low populations, limited provincial distributions, or demographic/life history features that make them vulnerable to human-related changes to the environment.

The Yellow List has been divided into two categories. Species listed as YELLOW A are those which merit extra attention as they have shown a long-term decline in numbers. The YELLOW B list includes species that are:

1) naturally rare but are not in decline;

2) naturally rare and have clumped breeding distributions; or

3) associated with habitats or habitat elements that are or may be deteriorating.

GREEN-LISTED species: These species are not considered at risk. Their populations are stable and their key habitats are generally secure at present.

STATUS UNDETERMINED: This category includes those species not known to be at risk but for which insufficient information is available at present to determine status.

The environmental change in the Grassland and Parkland Natural Regions of Alberta is underscored by the large proportion of species there that are currently at risk. Of the 9 species RED-LISTED for the province in 1996, there are $7(77.8 \%)$ that depend on Parkland habitats (Table 8). One-half (50\%) of the BLUE-LISTED species are also found in the Grassland and Parkland Natural Regions (Table 8). 


\begin{tabular}{|c|c|c|}
\hline $\begin{array}{c}\text { Table 8. The Status of Alberta Wildlife (Alberta Environmental Protection 1996b) } \\
\text { - species that occur or have occurred in the Parkland Natural Region }\end{array}$ \\
\hline Wildlife Group & RED-LISTED Species & BLUE-LISTED Species \\
\hline AMPHIBIANS & Canadian Toad & Plains Spadefoot Toad \\
\cline { 2 - 3 } & Northern Leopard Frog & Spotted Frog \\
\hline \multirow{4}{*}{ BIRDS } & Burrowing Owl & Ferruginous Hawk \\
\cline { 2 - 3 } & Peregrine Falcon & Short-eared Owl \\
\cline { 2 - 3 } & Piping Plover & Sprague's Pipit \\
\cline { 2 - 3 } & Whooping Crane & Long-billed Curlew \\
\cline { 2 - 3 } & Trumpeter Swan & \\
\hline MAMMALS & & Grizzly Bear \\
\hline
\end{tabular}

A brief discussion on each of these is included. Also included is a discussion of species on that report's YELLOW A and YELLOW B lists. Although not considered at risk, these species are generally those considered sensitive and vulnerable to changes to the environment. Information on the status of several of the species found in the Parkland is limited. These are on the STATUS UNDETERMINED list, and are also discussed below. Species on the GREEN list are not discussed. They are not considered at risk and have secure habitats and stable populations.

\subsubsection{Waterfowl}

The three prairie provinces produce about $60 \%$ of the waterfowl on the continent (DU \& ENR, n.d.). "The Grassland and Parkland Ecoregions provide the most significant complex of breeding habitat in the continent" (Poston et al. 1990, p30). Most of the production occurs in pothole complexes, small ponds a few acres in size, scattered across the Grassland and Parkland Natural Regions. Historically, Alberta has had some of the best waterfowl habitat and some of the highest waterfowl densities and productivity levels in North America; up to $40 \%$ of the total waterfowl production in the three prairie provinces (DU \& ENR, n.d.).

In addition to their importance as breeding areas, Alberta's wetlands are significant, both nationally and internationally, as moulting, stopover and staging areas for large numbers of migrating waterfowl, primarily from the Pacific and Central flyways. Northern-nesting species of geese, for example, rely primarily on Grassland and Parkland Natural Region habitats for staging during the fall and spring migration (Poston et al. 1990). An estimated one million Canada geese stage in the southern prairies, as does "most of the world's Lesser Snow Goose population" (ibid., p50). There has been a shift in the use of staging areas in the last 10 years caused perhaps by "changes in population size, weather and habitat conditions" (ibid., p55).

Larger marshes and lakes with stable water levels provide abundant food, adequate cover, isolation, and resting sites and are preferred areas for staging and moulting. Declines in natural wetlands along migration corridors can result in a greater concentration of waterfowl on the remaining areas. This can result in "more rapid depletion of food sources as well as posing potentially higher mortality risks from disease and other causal agents" (Nietfeld et al. 1985). 
Wetland habitats have been impacted or lost thereby "decreasing the habitat available for moulting, staging and migrant waterfowl" (ibid.). Losses of wetland habitats, combined with losses of native grasslands, have led to considerable declines in some waterfowl and other wetland-dependent species. The 1980s drought increased pressure on farmers to convert wetlands into cultivated fields. The dry conditions encouraged the ploughing of critical small wetlands. Changes in agricultural practices such as increased application of pesticides and fertilizers, aerial spraying and fencerow-to-fencerow farming has also negatively affected wildlife. Policies adopted by the Canadian government in the mid-1970s (e.g., encouraging agricultural expansion) also were implicated in reducing the amount of wildlife habitat. These factors in concert with a poor farm economy have forced prairie farmers in Canada to expand their operations, often into areas once considered "marginal" such as remnant native areas and hilly sections. Many wetlands and uplands used by wildlife as recently as the 1970s are no longer present (Nelson 1989). Important waterfowl areas such as small wetlands were some of the habitats most impacted (ibid.). "The very future of the waterfowl resource is being threatened by the expansion and intensification of agriculture" (AHJV 1989, p5).

Since approximately $95 \%$ of wetland habitats are associated with privately-owned land (DU \& ENR, n.d.), "the conservation and wise management of those and other remaining habitats is crucial to ensuring the future survival of wetland species" (Wetlands for the Americas, n.d.).

Recent efforts through the North American Waterfowl Management Plan are yielding positive results and waterfowl numbers appear to be improving (NAWMP 1996).

None of the waterfowl species that migrate through or rely on the Parkland for breeding habitat are considered at risk (AEP 1996). The one exception to this is the Trumpeter Swan. Although the main breeding population in Canada is now in the Grande Prairie area, there were two probable nesting locations reported for the grasslands in the Breeding Bird Atlas (Semenchuk 1992). Historically, Trumpeter Swans were widespread throughout North America. By the 1930s, their numbers and range were severely reduced, largely due to overhunting. In 1933, the known population was down to 66 birds, although this did not count those nesting in the Grande Prairie area or a population later discovered in Alaska (Shandruk 1987, p179). COSEWIC designated the Trumpeter Swan as rare in 1978. The status was changed to "vulnerable" in 1990 and in 1996 to "not at risk". The Alberta population has been increasing at about 7\% per year (Semenchuk 1992). The species, however, remains on the BLUE LIST (may be at risk), due largely to concerns regarding a "critical shortage of key winter habitat" (AEP 1996, p21).

\subsubsection{Other Wetland-Dependent Birds}

Grassland and Parkland Natural Region wetlands provide important habitat for a number of other wetland-dependant birds, including many colonial-nesting species such as pelicans, grebes and herons. Grassland and Parkland wetlands are extremely important to these species. Approximately $60 \%$ of the American White Pelican population, $20 \%$ to $50 \%$ of various grebe species, and $15 \%$ of the continent's Great Blue Heron population nest in the Grassland and Parkland wetland habitats of southern Canada (PHJV 1993, p6). These habitats include areas such as lake islands, wetland emergents and vegetation communities adjacent to rivers and 
streams. Five species associated with Grassland and Parkland wetlands are included on the YELLOW A LIST in the Status of Alberta Wildlife (AEP 1996), as follows:

American Bittern: Found in small numbers throughout North America, Finch (1992) considered the American Bittern a species of concern due to significant population declines in the United States. The declines were linked to agricultural conversion, accidental pesticide poisoning and habitat loss. One study suggested that the bittern is found only in wetlands with suitable habitat larger than 11 hectares (Brown and Dinsmore 1986, as cited in Finch 1992). The population status in Alberta is unknown, but declines are suspected. This solitary nesting bird "relies on permanent to semi-permanent wetlands with well-developed emergent vegetation. Drainage, consolidation and cultivation of these marshes is a continuing threat" (AEP 1996, p22).

Black Tern: This colonial species is "found throughout temperate North America and Eurasia" (Finch 1992). It "relies on [the] maintenance of larger marsh/wetland habitats" (AEP 1996, p22). Brown and Dinsmore (1986), as cited in Finch (1992), found that Black Terns were most common on wetlands larger than 20 hectares. The population status is unknown, but declines have been documented "in Saskatchewan, and over large parts of [the] North American breeding range." Semenchuk (1992) concludes that habitat loss is probably the main cause of declines, which were among the highest for any species counted in the Breeding Bird Survey (Finch 1992).

Horned Grebe: This grebe is primarily a western species, breeding from "central Alaska and northwestern Canada south to eastern Washington and east to Wisconsin" (Campbell et al. 1990). In Alberta, it breeds throughout the province, with populations concentrated in the southern boreal, Parkland and Grassland areas (Semenchuk 1992). The Horned Grebe is primarily a solitary nester but occasionally nests in small loose colonies. It prefers small wetlands for nesting, usually less than 5 hectares in size, with extensive marshy vegetation (ibid.). The population is declining throughout its Alberta range. "Breeding Bird Survey data show [a] sharp decline in the last two decades." This appears to be related to the loss of small wetlands due to drought (AEP 1996, p22).

Pied-billed Grebe: This solitary-nesting grebe is one of the most common in North America (Semenchuk 1992), breeding from "central Canada south throughout most of North, Central and South America" (Campbell et al. 1990). It breeds throughout Alberta, with most of the population being found in the Parkland and southern boreal areas, and significant numbers in the grasslands (Semenchuk 1992). Like the Horned Grebe, this species also prefers small wetlands with extensive marshy vegetation, but it is occasionally found in other wetland habitats (Semenchuk 1992). The population is declining throughout its Alberta range. "Breeding Bird Survey data from Alberta show declining numbers over the last two decades." This appears to be related to the loss of small wetlands due to drought (AEP 1996, p23).

Red-necked Grebe: This species breeds "from western Alaska across central Canada to Ontario, south to Washington and southern Wisconsin" (Campbell et al. 1990). It is primarily a solitary nester. About half of Canada's population of Red-necked Grebes breed in Alberta. Although the main population is found in the Parkland and southern boreal parts of the province, significant numbers are found in the Grasslands (Semenchuk 1992). This is probably Alberta's most common 
grebe, breeding in extensive marshy vegetation. Populations may be declining (AEP 1996) as a result of "pothole drainage, land clearing, environmental contamination and human recreational activities on lakes" (Semenchuk 1992).

Species found in Parkland habitats that are on the YELLOW B LIST for Alberta include:

American White Pelican: This species "breeds locally from southwestern Canada south to southern California, northern Utah, southern Montana and South Dakota" (Godfrey 1986). Although colonies are occasionally found on deep lakes or rivers, this pelican prefers shallow lakes with a good fish population (Semenchuk 1992). Nesting colonies are usually located on low, protected flat islands. Semenchuk (1992) summarized the population trends of this species as follows. Their populations declined in Canada until the 1970s, and in 1978 COSEWIC listed the pelican as threatened. Under protection, their populations rebounded from less than 16,000 breeding pairs in the mid-1970s to 50,000 in the 1980's. The species was then removed from the COSEWIC list in 1987. In Alberta, AEP (1996) estimates there are about 1000 nesting pairs scattered throughout the eastern half of the province. Their numbers are increasing, possibly due to birds moving in because of drought elsewhere. The number of active colonies, however, are decreasing and there is concern of a possible disease risk (ibid., p24.). Pelicans are vulnerable to pesticides and disturbances at their nesting site.

Black-crowned Night Heron: This is a small, widely distributed heron. In North America, it breeds "throughout much of the United States and central, southern and southeastern Canada" (Campbell et al. 1990). In Alberta, it nests primarily in the Grassland and Parkland Natural Regions (Semenchuk 1992). This night heron is a "colonial species, reliant on marsh habitat" (AEP 1996). Population trends are "downward in eastern Canada" (Desgranges and Laporte 1979 as cited in Poston et al. 1990, p73). Numbers, however, have increased in Alberta (AEP 1996). Semenchuk (1992) suggests that this species is "particularly susceptible to land clearing, drainage and human disturbance."

Double-crested Cormorant: This species is widespread, breeding from "southwestern Alaska, central Alberta, James Bay and Newfoundland south to Mexico and the Bahamas (Godfrey 1986). Although locally distributed in Alberta, the population is increasing. Once designated as endangered in Alberta, increasing populations allowed it to be removed from that list (AEP 1996, p26). Alberta colonies are generally located in the south and central portions of the province (Semenchuk 1992). They nest on flat, low-lying islands within large lakes having a good fish supply. Like pelicans, cormorants are vulnerable to disturbance at their nesting sites.

Forster's Tern: This tern breeds from southeastern British Columbia and the prairie provinces south through the eastern parts of Washington and Oregon to California, Colorado and Iowa, and up through to Wisconsin. There is also an Atlantic coastal population in the United States (Campbell et al. 1990a). In Alberta, the main population is in the Parkland and southern boreal forest, but there are also some colonies in the Grasslands. This tern "prefers the deeper portions of large cattail marshes" for nesting (Semenchuk 1992, p140). It is an uncommon species that breeds only locally and may be of concern due to loss of marsh habitat (AEP 1996; Semenchuk 1992). 
Great Blue Heron: This heron is wide-ranging, breeding throughout much of the northern and central Americas south to the Galapagos. In Alberta, they nest mainly in the central and southern areas of the province (Semenchuk 1992). Nesting is usually in trees near water and it feeds in the shallow waters of rivers, streams, wetlands and ditches. The Great Blue Heron is "suspected to be in decline throughout much of its range" in Canada (Poston et al. 1990, p72). In Alberta, however, "known colony numbers doubled between 1967 and 1980" (Brechtel 1981 as cited in Poston et al. 1990). The Alberta population is considered stable, with approximately 75 colonies and 1500 breeding pairs (AEP 1996). "Management of key habitats and protection from human disturbance is essential" (ibid., p26).

Marsh Wren: This bird commonly nests in cattails. It breeds across southern Canada south to California, New Mexico, Texas and Florida (Godfrey 1986). In Alberta, populations are concentrated in the Parkland, but it also occurs in the Grasslands. Its population status is unknown, but drought conditions over the past 10 years combined with impacts on Grassland and Parkland wetlands have eliminated some breeding areas (ibid., p27).

Sedge Wren: East-central Alberta is the north-western limit of this species' distribution. It breeds "east to eastern New Brunswick and south to Arkansas and south-eastern Virginia; also from southern Mexico south through Central America and south to southern South America" (Godfrey 1986). Godfrey (ibid.) considered the Sedge Wren a "scarce straggler to Alberta" but the Breeding Bird Atlas survey confirmed a centrally-located breeding population in the province, restricted to the Parkland and southern Boreal (Semenchuk 1992). It does not usually use cattail areas, instead nesting in marshy areas, often with scattered shrubs such as willow and alder (Godfrey 1986, Semenchuk 1992). It is "local and uncommon in Alberta" (AEP 1996). "Drought conditions combined with drainage of wetlands have degraded nesting habitat" (ibid.).

Western Grebe: This grebe breeds in western North America from southern British Columbia and the Canadian prairie provinces south to Mexico (Godfrey 1986). In Alberta, this species breeds as far north as Slave Lake. A significant portion of the population is also found in Grassland and Parkland habitats. They are "colonial nesters, usually found on medium to large lakes" (Semenchuk 1992, p41). They nest in emergent vegetation and although local and uncommon, populations in Alberta are believed to be stable (AEP 1996, p28). Disturbances such as "industrial developments, recreational activities and unstable water levels" are believed to cause this grebe to abandon otherwise suitable nesting habitat (Campbell et al. 1990).

Two wetland-dependant birds are on the STATUS UNDETERMINED list. Both are Rails; secretive birds that are difficult to census. The Virginia Rail nests in emergent vegetation such as areas with extensive bulrushes, cattails or sedges. Atlas observations were concentrated in the Grasslands and Parkland (Semenchuk 1992). The Yellow Rail is the most secretive of the Alberta rails and no breeding locations were confirmed during the Breeding Bird Atlas survey, but the majority of sightings reported were in the Parkland (ibid.). Habitat requirements appear to be similar to that of the Virginia Rail.

Colonial-nesting species and other wetland-dependant birds have been affected by habitat loss and degradation through land clearing, drainage and human disturbance. In addition, "toxic wastes 
and pesticides pose serious threats to these species because of their diets of fish and/or aquatic invertebrates" (Poston et al. 1990, p66). Colonial nesting species are "particularly vulnerable to site-specific disturbances and habitat changes" (ibid., p66).

\subsubsection{Shorebirds}

The Canadian plains region is an important migration staging area for Arctic-nesting shorebirds (Poston et al. 1990). About $80 \%$ of Lesser Golden Plovers, $75 \%$ of Baird's Sandpipers, $50 \%$ of Hudsonian Godwits, and 35\% of White-rumped Sandpipers stage in Canada's Grassland and Parkland Natural Regions during migration (PHJV 1993, p6). Short-billed Dowitchers and Sanderlings also frequent the Grassland and Parkland Natural Regions during migration (Salt and Salt 1976).

Shorebird migrations have evolved over thousands of years. "Many birds follow the same routes and use the same wetland areas along the way each year, making it difficult for them to respond to dramatic and rapid changes in the landscape" (Wetlands for the Americas, n.d.). "The occurrence of mud flats and shallow water habitats is critical to refuelling efforts of small shorebirds. These habitats are perhaps some of the most endangered habitats in the continent because of the rapid loss of wetlands due to agricultural conversion and extensive alteration of hydrologic processes" (Ostlie et al. 1996, p81).

In addition to being an important migration route, the Grassland and Parkland Natural Regions provide crucial breeding habitat for several species of shorebirds. Eighty percent of the continent's Marbled Godwits, $40 \%$ of the Willets, and $20 \%$ of all American Avocets and Wilson's Phalaropes nest on the plains (PHJV 1995, p6). The Piping Plover (RED-LISTED by Alberta, listed as endangered by COSEWIC), has been discussed previously in Chapter 1.6.

Lesser Yellowlegs: The Lesser Yellowlegs is a shorebird on the YELLOW A list. It breeds from Alaska, through most of western Canada to James Bay (Godfrey 1986). Although essentially a Boreal/Canadian Shield species, a significant portion of the Alberta population was found to breed in the Parkland (Semenchuk 1992). This was once considered one of North America's most common medium-sized shorebirds (Johnsgard 1981 as cited in Semenchuk 1992). However their populations "show (a) sharp decline in (the) last 15 years" (AEP 1996). This decline is attributed to the loss of wetlands (ibid.). The Lesser Yellowlegs nests in "dry, lightly wooded areas close to water" and moves to wetlands to raise the young (Semenchuk 1992). Clearing of woodlands adjacent to wetlands may also have contributed to their decline.

Three additional shorebird species are on Alberta's YELLOW B LIST, as discussed below.

American Avocet: The avocet is primarily a western species, breeding in southeastern British Columbia through the southern prairies and southwest Ontario south to the southwestern United States (Campbell et al. 1990a). In Alberta, it is found mainly in the Parkland and Grassland areas of the province. It "favours the shallow muddy borders of saline or alkaline lakes or sloughs" (Semenchuk 1992). Although locally abundant, "drought and the degradation of prairie wetlands have further restricted the distribution of this species" (AEP 1996). 
Black-necked Stilt: This species favours "shallow and brackish pools, marshes and lakes, especially where there are extensive areas of mudflats" (Semenchuk 1992, p117). It breeds locally north from south America through to southern Washington (Campbell et al. 1990a). Here it is at the northern edge of its range, and southern Alberta is the only place it breeds in Canada (Semenchuk 1992). "In the past, breeding has been confirmed at Beaverhill Lake, New Dayton and near Calgary." Of five confirmed breeding records during the breeding bird survey, one was in the Parkland (ibid). Few populations and localized distribution make it vulnerable to habitat loss (AEP 1996).

Willet: This species "breeds in the prairie regions of Canada, the northwestern United States, and on the Atlantic coast from Nova Scotia to northern Mexico" (Campbell et al. 1990a). It frequents "moist and wet meadows and the grassy edges of prairie sloughs and lakes" (Semenchuk 1992). Although the Breeding Bird Atlas surveys found it to be common in Alberta Grassland and Parkland Natural Regions (ibid.), there is some evidence that populations may be declining (AEP 1996), possibly due to drought and wetland drainage, particularly in the Grassland and Parkland.

Wetland loss and degradation have affected shorebird populations (Howe, 1987). Howe et al. (1989), in their analysis of International Shorebird Survey data, found that Short-billed Dowitchers and Sanderlings experienced significant declines in their numbers between 1972 and 1983. Population declines for these species ranged between 46 and $80 \%$. Many shorebird species have suffered precipitous declines, some by as much as $80 \%$ in the last 25 years (Wetlands for the Americas, n.d.).

\subsubsection{Landbirds}

According to Partners in Flight - Canada (1996), landbird populations in both the United States and Canada have shown long-term declines over the last 30 years. This includes many neotropical migrant species. Declines in some forest edge and grassland species that winter in the United States have also been reported for Canada and the United States. The Greater Prairie Chicken is considered extirpated in Alberta and Canada and was discussed earlier. There is one species of landbird found in the Parkland that is on the BLUE LIST for Alberta, the Sprague's Pipit.

Sprague's Pipit: This species breeds from the Grassland and Parkland Natural Regions of Canada south to Montana, North Dakota and northwestern Minnesota (Godfrey 1986). In Alberta, it breeds in the Grassland and Parkland areas of the province. It seems to be intolerant of heavy grazing, but will use moderately grazed areas (Semenchuk 1992). It seems unable to use nonnative habitats and so its potential range has been reduced (ibid.). Prescott and Wagner (1996) found Sprague's Pipit only on native Grassland and Parkland pastures. Breeding Bird Survey data have documented "dramatic population declines" (AEP 1996).

A number of Parkland species are on the YELLOW A LIST for Alberta. One, the Loggerhead Shrike, is listed by COSEWIC as threatened and was discussed earlier. The others are as follows:

Baird's Sparrow: This species "has a restricted breeding range, occurring only in the northern Great Plains" (Finch 1992). In Canada, it breeds in southern Alberta, southern Saskatchewan and southwest Manitoba. Historically, it was very abundant in the mixed grass and tall grass prairies. 
Now, it "probably exists at less than 5\% of its former levels" (De Smet and Miller 1989). Although Breeding Bird surveys indicate significant continent-wide declines from 1966 to 1985 (Finch 1992), recent work suggests that there is "insufficient evidence" from productivity data "to conclude whether the total population is stable, increasing or decreasing" (Goossen and Dale 1996, p10).

This species prefers nesting sites with tall, dense grasses and shrubs. Wershler (1990) noted that "fescue grassland is the principal habitat type in Alberta currently used by Baird's Sparrows, followed by mixed grassland, dry lakes and ponds, and riparian meadows." It usually does not breed in grasslands that have been moderately to heavily grazed because of its preferences for tall, dense grasses. Loss of quality nesting habitat as a result of "intensive agriculture, heavy grazing, and other high impact land use activities appear to be major limiting factors affecting Baird's Sparrows" (Goossen et al. 1993). It has been found that "land on which grazing is done on a rotational basis can support nearly ten times as many Baird's Sparrows as continuously grazed pasture" (RENEW 1996, p6). Although on the YELLOW A LIST, more information is required on the apparent population declines of this species to clarify its status (AEP 1996).

Brown Thrasher: Brown Thrashers in Alberta are at the northwestern edge of a range that extends east to Quebec and Maine and south to Florida. They breed in the Parkland, but the main Alberta population is in the Grassland Natural Region, where tall shrubbery in coulees is the preferred habitat. Although considered by Semenchuk (1992) to be relatively common in Alberta's grasslands, AEP (1996) concludes that the population status is unknown but may be declining. Based on this, the Brown Thrasher was placed on the YELLOW A LIST for Alberta.

Clay-colored Sparrow: This sparrow breeds west to the interior of British Columbia, north to the southern Mackenzie area, east to southern Ontario and south as far as northern Texas (Godfrey 1986). It is found throughout Alberta, but most commonly in the Grassland and Parkland Natural Regions (Semenchuk 1992). It prefers shrubby grasslands, shrubby openings in woodlands and shrublands adjacent to watercourses and wetlands. It nests near the ground in shrubs or small trees. Although a common bird in Alberta, it is on the YELLOW A LIST. Populations were considered to be healthy and stable in 1991, but Breeding Bird Survey data show a declining population in recent years. Reasons for the recent population declines have not been documented (AEP 1996).

Sharp-tailed Grouse: This grouse is widespread, ranging from Alaska and across Canada as far east as Quebec and south to "eastern Oregon, northern Utah, Colorado, Minnesota and northern Michigan" (Godfrey 1986). It occupies a variety of habitats. In the Grassland and Parkland Natural Regions, it prefers large expanses of grassland, preferably with a shrub component. Population abundance is dependent on open grassland/shrubland during the mating season. According to Alberta Forestry, Lands and Wildlife (1991), "the retention of undisturbed grassland habitat is essential for the continued welfare of Sharp-tailed Grouse populations in Alberta." Initially, with settlement, the interspersion of large tracts of native vegetation with cropland areas benefited grouse distribution and numbers. However, "with the advent of modern, intensive clean-farming practices, populations have declined as the diversity has been decreased" (Nietfeld et al. 1985). Intensive grazing has also been known to cause declines in grouse populations 
(ibid.). The species is currently on the YELLOW A LIST for Alberta, but considered relatively common (AEP 1996).

Upland Sandpiper: This species "breeds from Alaska through the Canadian Grassland and Parkland Natural Regions and the northern United States south to Oklahoma and Texas (Finch 1992). It uses open grassy areas for foraging and nesting, rarely using cultivated fields. Once found extensively in the province, it now occurs primarily in the Grassland Natural Region, with only scattered populations elsewhere (Semenchuk 1992) The population status is unknown, but "populations probably have declined with loss of native prairie grassland nesting areas" (AEP 1996).

Western Meadowlark: This species nests on the ground in grassy areas with adequate cover to conceal the nest. While some studies suggest it is found only on non- or lightly-grazed grasslands, others suggest grazing intensity is not a factor (Prescott and Wagner 1996). The Western Meadowlark breeds from British Columbia east to southern Ontario and south to northern Mexico, central Texas and Louisiana (Godfrey 1986). The majority of breeding pairs in Alberta are found in the grasslands. There has been a long-term decline in numbers, particularly in Parkland populations, perhaps due to a reduction in open grassland (AEP 1996).

The following species are on the YELLOW B LIST for Alberta:

Bobolink: This species breeds throughout southern Canada, south as far as West Virginia, Pennsylvania and New Jersey (Godfrey 1986). In Alberta, it breeds irregularly in the central and southern areas of the province, preferring habitats such as open meadows and hayfields with tall grasses rather than native Grassland and Parkland (Semenchuk 1992). The Bobolink appears to be a species that expanded its range as settlers provided suitable habitat by developing pastures and hayfields (ibid.). This bird is included on the YELLOW B LIST since it is a species of localized distribution. Numbers are low, with less than 500 breeding pairs in Alberta (AEP 1996).

Brown Creeper: The Brown Creeper is widely spread in both North America and Europe (Godfrey 1986). It is found throughout the southern half of Canada, excepting the grasslands (ibid.). Population levels are poorly understood, but are of concern due to its reliance on mature woodlands for nesting.

Great Crested Flycatcher: Formerly thought to breed only as far east as Saskatchewan (Godfrey 1986), it has now been confirmed as nesting in the Parkland of east central Alberta (Semenchuk 1992). From Alberta, it ranges east across southern Canada, south to Florida, the Gulf coast and central Texas. Although it does not appear to be affected by fragmentation of forest stands, it does require mature trees for nesting, preferably deciduous trees ( $i b i d$.). Although population levels are unknown, there are "probably less than 300 breeding pairs in the province" (AEP 1996).

Lark Sparrow: This is primarily a grassland species, found mainly in "semi-open areas in river valleys and coulees, as well as sandhills" (Semenchuk 1992, p281). It is "uncommon" and "locally distributed." It is "blue listed in B.C." and "a large portion of the Canadian range occurs in Alberta" (AEP 1996). In Canada, it breeds from the interior of British Columbia across the prairie provinces with a population in southwestern Ontario. It breeds as far south as southern 
California, northern Mexico, Louisiana and central Alabama (Godfrey 1986).

Pileated Woodpecker: A species that requires large, mature trees for nesting, its abandoned nesting cavities also provide important habitat for other forest species. Although the population is likely stable (AEP 1996), it is this need for mature trees that causes the Pileated Woodpecker to be of management concern. This is a resident species found "across forested Canada and the United States south to California, the Gulf coast and Florida" (Campbell et al. 1990a). In Alberta, it is found in all forested regions, including the Parkland. There are also some breeding records from riverine woodlands in the Grassland Natural Region (Semenchuk 1992).

Western Tanager: The Western Tanager is found in all of Alberta's forested regions, including the Parkland. It is a western species, breeding from Alaska south to Baja California and western Texas. In Canada, it is found only as far east as central Saskatchewan. It is a forest species, preferring old, open coniferous and mixed woods, avoiding dense coniferous stands (Semenchuk 1992). Population trends for Alberta are unknown, although declines have been noted in other areas (AEP 1996). The need for mature forests for breeding habitat and habitat changes in wintering areas are reasons that cause this species to be of management concern.

One additional species, the Black-billed Cuckoo is a species listed as STATUS UNDETERMINED. "When found, the cuckoo appears within brushy thickets along the roads and streams of the Parkland Natural Region" (Semenchuk 1992). It is also found in shrubby coulees in the Grassland. This is a secretive bird that appears to be uncommon, but little is known about its status.

\subsubsection{Raptors}

Raptor species that have been assigned status by COSEWIC were discussed earlier, in Chapter 1.6. These include the Burrowing Owl (endangered), the Ferruginous Hawk (vulnerable), the Peregrine Falcon (endangered) and the Short Eared Owl (vulnerable). Three additional Alberta raptors found in the parkland are on the YELLOW A List, and four on the YELLOW B list, as follows.

The following species are on the YELLOW A List.

Northern Harrier: This harrier is widespread, breeding from coast to coast and from Alaska south to Mexico (Campbell et al. 1990a). In Alberta it breeds in the Grassland, Parkland and southern Boreal Natural Regions. It hunts in open country and nests on the ground in areas of adequate cover, often among rose and buckbrush (Semenchuk 1992). Populations appear to be declining overall, especially in eastern North America (ibid.). Although Alberta populations were considered stable in 1992 (ibid.), Grassland and Parkland populations in the province now appear to be declining, perhaps due to the deterioration of foraging and breeding habitats (AEP 1996). Finch (1992) lists a number of factors that have affected this species, including: agricultural conversion, overgrazing, accidental pesticide poisoning, disturbance and loss of habitat.

Prairie Falcon: This falcon is a western North American species, breeding from south-central British Columbia through Alberta and southwestern Saskatchewan and south to Baja California, 
New Mexico and northern Texas (Campbell et al. 1990a). In Alberta, it breeds primarily in the Grassland Natural Region (Semenchuk 1992). It nests in cliffs of badlands, coulees and river valleys and hunts in adjacent grasslands. The species depends on "secure nest sites and [an] adequate ground squirrel prey base" (AEP 1996, p23). Declines in the range and population of this falcon have occurred in Canada. In the Okanagan Valley of British Columbia, for example, declines have been linked to human interference at nest sites, increasing use of organochloride pesticides and food deficiencies related to the population being at the northern limit of their range (Campbell et al. 1990a). In Alberta, the bounties that were in effect for this bird during the 1920s and 1930s could have reduced its historical range in the province. Although Semenchuk (1992) suggests that the Canadian population is stable and perhaps increasing, AEP (1996) concludes that population trends in Alberta are unclear.

Swainson's Hawk: This hawk breeds primarily in southern Alberta, southern Saskatchewan and southwest Manitoba, and south to Mexico (Godfrey 1986). "Swainson's Hawk breeds in dry, open country where trees and shrubs are available for nesting. Highest densities of this hawk [in Alberta] are found at the Grassland/Parkland border" (Semenchuk 1992). Ground squirrels are one of its main foods. Aggregations of "300 to 400 birds feeding on grasshoppers" were reported in 1893 in British Columbia, but no aggregations of this magnitude have been reported since the 1920s (Campbell et al. 1990a). Declines in British Columbia were related to declining cricket and grasshopper prey on the breeding grounds, declining locusts on the wintering grounds and persistent shooting (ibid.). There have been "sharp declines in prairie populations over the last decade", in part due to mass poisoning in their wintering areas (AEP 1996).

The following species are on the YELLOW B list.

Broad-winged Hawk: This is a tree-nesting species that breeds in woodlands from central Alberta, east across southern Canada and south into Texas, the Gulf coast, southern Florida and the West Indies (Godfrey 1986). The main nesting area in Alberta is a narrow strip in the eastcentral part of the province that includes the Parkland and the southern part of the Dry Mixedwood Boreal Natural Subregions. It appears to rely on mature and old growth forests and a population decline has been noted in the Parkland, particularly around urban areas (AEP 1996).

Cooper's Hawk: The Cooper's Hawk breeds "from southern Canada south to north-western Mexico, south-central Texas, central Alabama and central Florida" (Godfrey 1986). Listed as "vulnerable" in 1983, it was delisted in 1996 (COSEWIC 1997). In Alberta, population levels are unknown, but loss of habitat, particularly the "clearing of parkland aspen bluffs threatens nesting habitat" (AEP 1996). Semenchuk (1993) notes that populations have declined, due largely to loss of nesting habitat, pesticide contamination and over hunting. The highest nesting concentrations in Alberta are in the southern Boreal and Parkland regions; it prefers dense woods to edge habitat (Semenchuk 1992).

Golden Eagle: This eagle is widespread, found throughout North America to central Mexico and also occurring in Europe and Asia. Once the target of an eradication program, populations dropped, but they now appear to be stable or increasing (Campbell et al. 1990a). The Golden Eagle "prefers open areas with short or sparse vegetation, especially slopes and plateaus that 
allow a commanding view" (Semenchuk 1992). Although found in other scattered locations, the main Alberta populations are concentrated in the mountains and along the major river valleys in the grasslands. In the grasslands, it nests in badlands, coulee edges and river valleys. The Golden Eagle is on the YELLOW B LIST for Alberta as a species with a low but apparently stable population of 100 to 250 breeding pairs (AEP 1996).

Turkey Vulture: Alberta represents the northern limit of a range that extends from southern Canada, through the United States south to the West Indies and into southern South America (Godfrey 1986). Here they are "rare and local breeders," with records concentrated in the Cold Lake and Big Valley areas (Semenchuk 1992), although AEP (1996) suggests that nesting is primarily in the Red Deer River valley. They prefer to nest in remote, undisturbed sites, selecting rocky outcrops, caves or crevices in cliffs. There are probably less than 100 nesting pairs in the province, and population trends are unknown (ibid.).

\subsubsection{Reptiles and Amphibians}

Patriquin (1993, p45) lists several priority reptile and amphibian species for the Parkland Natural Region. These include Canadian (Dakota) Toad, Northern Leopard Frog, and Plains Spadefoot Toad. Most of these species are considered at risk and all depend on "adequate, quality habitat at critical seasons for their continued viability" (Fisher and Roberts 1994, p15).

Canadian Toad: This is a central North American species, found from the Northwest Territories south through eastern Alberta to about the latitude of Lake Newell, through most of Saskatchewan and south-central Manitoba, south to South Dakota and east to northern Minnesota (Russell and Bauer 1993). It breeds in shallow, often temporary waterbodies. Significant population declines of this species have been documented since 1986 across its Alberta range, especially in agricultural areas (Patriquin 1993, p41). It was "once common in boreal and Parkland habitats" but there has been a "dramatic decline in [the] Parkland distribution." It is on the RED LIST for Alberta (AEP 1996, p19).

Northern Leopard Frog: This species "is distributed widely across the United States, Mexico and Canada" (Finch 1992). It lives in permanent waterbodies with abundant vegetation (Russell and Bauer 1993). The Northern Leopard Frog has experienced "a catastrophic decline in numbers and range" (Powell and Russell 1996). Once found in Alberta north to the Little Smoky River, it is now found only in the Grassland and Parkland Natural Regions (Russell and Bauer 1993). Most of the populations remained healthy until about 1979. They then began to disappear from many sites in the central and southern parts of the province. According to Roberts (1992), all populations have disappeared north of 51 degrees latitude. "Populations south of this line have also suffered in recent years, and those remaining are limited to small areas around springs, seeps, creeks or small ponds" (Patriquin 1993, p41). This species is on the RED LIST for Alberta due to the severe decline in numbers. It is considered extirpated from the North Saskatchewan River drainage basin (AEP 1996, p19).

Plains Spadefoot Toad: In Alberta, this toad is found south of the Red Deer River and west to Pincher Creek. The Alberta population is at the northwestern limit of a range that extends east to 
Manitoba and south to Mexico and eastern Arizona (Russell and Bauer 1993). It has a "highly variable" population, based on "annual availability of breeding ponds" (AEP 1996, p20).

Breeding ponds are usually temporary waterbodies in areas with "sandy or friable soil appropriate for burrowing" (Russell and Bauer 1993, p62). Drought combined with wetland drainage and basin cultivation has likely decreased available habitat. The Plains Spadefoot Toad is on the BLUE LIST for Alberta (AEP 1996, p20).

Scientists have had difficulty explaining the worldwide disappearance of many amphibian species. Causes may involve a combination of unusual local conditions related to drought, frost, disease, acid rain and loss of habitat. Other possible causes include global warming, introduction of exotic competitors, predators, pathogens, changes in ultraviolet radiation levels and the general contamination of air, soil and water (Heyer 1996, p11; Microsoft Internet Explorer 1996). According to Heyer $(1996$, p11), "the single greatest threat to amphibian disappearances is habitat modification."

Fisher and Roberts $(1994$, p21) propose that "wetland drainage, upland cultivation, and the use of chemicals have all contributed to the dramatic decline of the Northern Leopard Frog, Canadian Toad and Great Plains Toad in Alberta." Amphibians are extremely sensitive to water pollutants such as pesticides and herbicides. Fisher and Roberts $(1994$, p21) also postulate that these factors are probably responsible for eliminating much of the historical amphibian and reptile community on one of their study areas the Medicine Wheel Landscape. Loss, degradation and fragmentation of habitats have all affected the reptile and amphibian populations of the Grassland and Parkland Natural Regions .

The three species of garter snake in Alberta are also considered species of concern and are on the province's YELLOW A LIST. The Plains Garter Snake and the Wandering Garter Snake are primarily grassland species but range widely into the Parkland. The Red-sided Garter Snake is found scattered throughout Alberta, but primarily in the Parkland and Boreal Forest (Russell and Bauer 1993). All these species are considered "common but localized" (AEP 1996). There apparently is a common perception that the Plains and Red-sided Garter Snakes have been undergoing a long-term decline in numbers (ibid.), however, population trends for all three species remain essentially unknown.

\subsubsection{Fish}

There are 51 native and 8 introduced fish species in Alberta (Nelson and Paetz 1992). Several species that occur within the lakes and rivers of the Parkland Natural Region have been classified by the Alberta Natural Heritage Information Centre (ANHIC) as "trackable species" (i.e., species that either have a limited distribution and small populations, or for which current information is lacking). Species provincial ranks are defined as follows. 


\section{Provincial Ranking Guidelines}

\section{RANKS* GENERAL CRITERIA}

S1 5 or fewer occurrences in Alberta or only a few remaining individuals. May be especially vulnerable to extirpation because of some factor of its biology.

S2 6-20 or fewer occurrences in Alberta or with many individuals in fewer locations. May be especially vulnerable to extirpation because of some factor of its biology.

S3 21-100 occurrences, may be rare and local throughout Alberta, or in a restricted provincial range (may be abundant in some locations). May be susceptible to extirpation because of large scale disturbances.

S4 Typically $>100$ occurrences. Apparently secure.

S5 Typically $>100$ occurrences. Demonstrably secure.

*ranks can be combined to indicate a range (e.g. S2S3 = May be imperiled or rare throughout range, but the exact status is uncertain). Combined ranks indicate a margin of error.

The trackable species that occur in the Parkland of the province are discussed below.

As Ostlie et al. (1996, p84) suggest, the "conversion of natural vegetation coupled with mechanical alteration of river and stream habitat (e.g., by dams, road-building, etc.) has greatly impacted the fish fauna of the prairie biome." Alberta has not escaped these impacts.

Bull Trout: This species occurs in northwestern North America from southern Alaska to California. In Alberta, it is known from the Peace, Athabasca, North Saskatchewan, Red Deer, Bow and Oldman river drainages (Nelson and Paetz 1992). "There has been a significant reduction in the range of this species..., especially in the eastern portion of their range in Alberta" (ibid.). According to Alberta Environmental Protection (1996a), the Bull Trout has been eliminated from most of its historic prairie range primarily because of "habitat changes and overfishing". One of the last populations of this species on the prairies, currently found in the downstream reaches of the Oldman River, is under threat and may "disappear if its migration path continues to be blocked" by dams (Nelson and Paetz 1992). The Bull Trout has been ranked by $\mathrm{ANHIC}$ as an $\mathrm{S} 3$ species for the province.

Quillback: The Quillback is found from Alberta to southern Quebec and eastern Missouri to Virginia. It is known from "central and southern Alberta from the North Saskatchewan, Battle, Red Deer, lower Bow, lower Oldman, and South Saskatchewan rivers" (Nelson and Paetz 1992). In Alberta, the Quillback "has been recorded from sluggish and usually turbid rivers but not from lakes. Nothing is known of their spawning habits in Alberta" (ibid.). It has been ranked by $\mathrm{ANHIC}$ as an $\mathrm{S} 2$ species for the province.

River Shiner: This shiner is found from Alberta to eastern Manitoba, south to Oklahoma and 
eastward to Pennsylvania. "It is sporadic in central and southern Alberta" (Nelson and Paetz 1992). It occurs in the North Saskatchewan, Red Deer, lower Bow, lower Oldman, and South Saskatchewan rivers (ibid.). This species prefers large streams that flow over sandy and gravel substrates. It has been ranked by ANHIC as an S2 species for Alberta.

Silver Redhorse: This fish is found from Alberta to southern Quebec and Missouri to northern Georgia. In Alberta, it is known "only from the North Saskatchewan River between Devon and the Sturgeon River..., and the South Saskatchewan River at Medicine Hat" (Nelson and Paetz 1992). The Silver Redhorse "frequents large rivers, especially pools or areas of slow gradient. It has not yet been found in any Alberta lakes" (ihid.). Information is lacking on the biology of this species in Alberta. It has been ranked by ANHIC as an S2 species for the province.

Spoonhead Sculpin: This fish occurs from "northeastern British Columbia to Quebec with northward extensions to the mouth of the Mackenzie River and southward to Michigan" (Nelson and Paetz 1992). In Alberta, it is known from the "Slave, Peace, Athabasca, North Saskatchewan, upper Red Deer, Bow and upper Oldman river drainages." It is "most abundant in streams in the foothills and adjacent plains" (ihid.). The Spoonhead Sculpin has been ranked by $\mathrm{ANHIC}$ as an $\mathrm{S} 3$ species for the province.

\subsubsection{Mammals}

A number of mammal species that inhabit the Parkland are on the lists of species of concern for Alberta. The prairie population of the Grizzly Bear is listed by COSEWIC as extirpated, and is discussed in Chapter 1.6. Those mammal species found in Grassland and Parkland Natural Region habitats that are on the YELLOW A LIST for Alberta are discussed below.

American Badger: Badgers are found from central Mexico north through the central and western United States to the Great Lakes and into southern Ontario, southwest Manitoba, central Saskatchewan, central Alberta and southeastern British Columbia (Banfield 1974). In Alberta, badgers are essentially restricted to the Grassland and Parkland Natural Regions (Smith 1993). They rely on ground squirrels and pocket gophers for prey. Badger burrows "provide a key habitat element for Burrowing Owls" (AEP 1996, p23). Population trends are presently unknown (ibid.).

Long-tailed Weasel: This weasel is widespread, ranging from southern Canada to South America (Banfield 1974). It is a species of the "grassland, parkland and coniferous forests" and is found throughout the southern two-thirds of the province (Smith 1993). AEP (1996) suggests that this species is disappearing from some areas as habitat is lost. Smith (1993) indicates that the grassland populations may be in decline, but evidence is lacking.

Richardson's Ground Squirrel: As a central Plains species, it reaches the northwestern limit of its range in Alberta's Grassland and Parkland areas (Banfield 1974). Although a common species, populations are in decline and, therefore, it was placed on the YELLOW A LIST for Alberta (AEP 1996). The decline is thought to be caused by "effective poisoning campaigns and habitat alteration ... Populations [are] increasingly fragmented and restricted to remnants of unbroken 
ground" (ibid., p24). The Richardson's Ground Squirrel is an important species to the ecology of the Parkland. It is a key prey of species such as Ferruginous Hawk (BLUE-LISTED), Prairie Falcon (YELLOW A-LISTED), Swainson's Hawk (YELLOW A-LISTED) and Badger (YELLOW A-LISTED). It's burrows may be a critical component of Burrowing Owl (REDLISTED) nesting habitat.

Thirteen-lined Ground Squirrel: This species is found from east-central Alberta across to Manitoba. Its range continues east to south of the Great Lakes to Ohio and south in the Great Plains to the Gulf of Mexico (Banfield 1974). In Alberta, it is a species of the southern Parkland and Grasslands. There is some concern that populations may be declining, but the status is essentially unknown (AEP 1996).

The three Parkland mammals on the YELLOW B LIST for Alberta (Bobcat, Cougar and Pronghorn) are discussed below.

Bobcat: This wide-ranging species is found throughout southern Canada, north to central British Columbia and south throughout the United States and into Mexico (Banfield 1974). In Alberta, it is basically restricted to the coulees and river valleys south of the South Saskatchewan River. It does, however, range further north in the foothills and front ranges (Smith 1993), and likely occurs in the Foothill Parkland Subregion. Populations are low (less than 1000 individuals) but "presumed stable" (AEP 1996).

Cougar: This was once a widely-distributed species, ranging from southern Canada, throughout the United States, south to South America (Banfield 1974). It has however been extirpated from much of its historical range (ibid.). Although found throughout Alberta, its main range is the southern Rockies and foothills, including the Foothills Parkland (Smith 1993). The population appears stable (AEP 1996).

Pronghorn: Pronghorn occur throughout the Great Plains, the high sagebrush steppes and valleys of the Great Basin, and portions of south-central Canada and northern Mexico. They reach the northern limits of their North American range in the Parkland of south-central Canada. From herds historically in the millions, their numbers had dropped to about 20,000 animals by 1908 (Banfield 1974). Populations have since increased significantly, but they remain extirpated from areas of their former range (ibid.). Pronghorn typically avoid rugged areas and dense, tall vegetation that restricts their visibility (Ockenfels et al. 1996).

Pronghorn are usually limited by "large tracts of intensively cultivated land where protective cover and suitable forage is scarce and fences impede movements" (Nietfeld et al. 1985). They are also affected by shrub and tree encroachment (Ockenfels et al. 1996). Highways and railways fragment their habitats and impede travel, particularly when fenced on both sides (ibid.). This becomes critical in severe winters if migration to suitable wintering habitat is blocked.

Their "population levels fluctuate depending on winter and summer climatic conditions" (AEP 1996, p29). This situation was a determining factor for including this species on the YELLOW B LIST for Alberta. 


\section{Chapter 1.8 What is Being Done?}

Many individuals, groups, agencies and industries are aware of the state of Grassland and Parkland Natural Region habitats and species and have taken steps to help conserve and restore those ecosystems. Much is being accomplished on a variety of fronts. Some of the programs, plans and initiatives include:

- The Ramsar Convention

- Prairie Habitat Joint Venture under NAWMP

- The Mixedgrass Prairie Habitat Restoration Project under NAWMP

- Adopt-a-Pothole Program

- Prairie Shores Program

- Wetlands for Tomorrow Program

- Recovery of Nationally Endangered Wildlife Program

- Endangered Species Recovery Fund

- Prairie Care Program

- Heritage Marshes Program

- The Alberta Prairie Conservation Action Plan

- Operation Burrowing Owl

- Operation Grassland Community

- Landowner Habitat Program

- Riparian Habitat Management Program

- Wildlife Habitat Development Program

- The Permanent Cover Program

- Alberta Water Management \& Erosion Control Program

- Soil Conservation Area Program

- Fisheries Management Enhancement Program

- Fisheries Habitat Development Program

- Buck for Wildlife Program

Since the release of the Prairie Conservation Action Plan (PCAP) in 1988, considerable effort has been put forward and accomplishments made to meet its goals focusing on the preservation of native prairie, including Parkland. Those goals were: (1) identify the remaining native Grassland and Parkland habitats, (2) protect at least one large, representative area in each of the three Parkland Subregions, (3) establish a system of protected ecosystems and connecting corridors, (4) protect threatened ecosystems by implementing habitat restoration and management plans, (5) protect and enhance populations of vulnerable, threatened, endangered, or extirpated species, (6) ensure that no additional species become vulnerable, threatened, endangered, or extirpated, (7) encourage government to incorporate the conservation of native Grassland and Parkland Natural Region habitats into their programs, (8) encourage the sustained use of private land while maintaining and enhancing the native biological diversity of the Grassland and Parkland Natural Regions, (9) promote public awareness of the value and importance of Grassland and Parkland species, and (10) promote research into Grassland and Parkland conservation (World Wildlife Fund 1988). PCAP's accomplishments are documented in its 1994-1995 Annual Report (Prairie Conservation Forum 1996). 
In February of 1997, the Alberta Prairie Conservation Action Plan was released as a successor to the 1988 Prairie Conservation Action Plan that was prepared for Canada's three prairie provinces. The Alberta PCAP "promotes the conservation of native prairie and Parkland species and habitats while affirming the importance of community cooperation and respecting the stewardship of local landholders" (Creasey 1997). The plan's four goals are: (1) advance the identification, understanding and use of information about Alberta's Grassland and Parkland ecosystems, (2) ensure governments at all levels have in place policies, programs and regulations that favour the conservation of Alberta's native Grassland and Parkland ecosystems, (3) adopt land use management practices and protective strategies across the whole Grassland and Parkland landscape that sustain diverse ecosystems, and (4) increase awareness of the values and importance of Alberta's native Grassland and Parkland ecosystems (Prairie Conservation Forum 1997).

Many groups and individuals across Canada have cooperated under the North American Waterfowl Management Plan to restore wetlands and associated habitat critical to the breeding, staging, and wintering of many species of wildlife. Partners have conserved and enhanced over a half million hectares of wetland and other habitat in Canada (e.g., the 19,000 ha Medicine Wheel project in Alberta). They have also encouraged land use practices to enhance the value of agricultural land to wildlife. Today, assisted by several seasons of high precipitation, waterfowl numbers are increasing and other species are benefiting (NAWMP 1996).

The Energy Resources Conservation Board, along with several Alberta Government agencies, has compiled guidelines for reducing disturbance on native prairie and Parkland areas (ERCB 1992). These agencies are working with industry to monitor the effectiveness of the guidelines in reducing the loss of native prairie and Parkland habitats to oil and gas projects. Some recent efforts of industry in attempting to minimize the disturbance to native prairie areas are encouraging. For example, the Express Pipeline Project, which extended from Hardisty to Wildhorse in Alberta (National Energy Board 1996), incorporated several mitigation techniques in their construction and operation plans, including:

- choosing construction schedules (i.e., August to November) to avoid nesting seasons and critical life-cycle phases of fish species,

- $\quad$ shifting alignments, where possible, to avoid wetlands and lakes, significant plant communities and other valued natural areas,

- scheduling cleanup activities to avoid important occupied denning and reproductive habitats,

- restricting topsoil stripping to an area only slightly wider than the ditch wherever possible,

- employing soil erosion control measures (e.g., mulching),

- installing temporary fencing to protect river banks,

- washing mud and vegetative debris off equipment to prevent weed transfer,

- $\quad$ using native seed mixes, as much as possible, for reclamation, and

- revegetating riparian areas along affected rivers using local native plant species.

Within the agricultural community there are several ongoing projects to reduce degradation of riparian areas, and to increase the value of arable and pasture lands to wildlife (Alberta Environmental Protection 1994a, 1996a; Bentley 1988; NAWMP 1996). These include: 
- the use of conservation tillage practices (e.g., trash cover farming),

- rotational grazing practices,

- $\quad$ under the Riparian Habitat Management Program, livestock grazing management strategies are being developed and tested for the protection of streams and riparian areas,

- restoration of native grass communities,

- the involvement of agricultural scientists in the development of mitigative and protective methodologies,

- agricultural research efforts regarding soil and crop management practices that maintain and protect the productivity of cultivated farmlands,

- taking marginal land out of cultivation. For example, "since 1989, more than 144,000 ha of environmentally sensitive farmland in Alberta was returned to permanent cover of grass or trees" (Alberta Environmental Protection 1994a),

- establishment of permanent forage on marginal lands,

- farmers who are actively involved in maintaining and improving the productivity of their cultivated lands (e.g., reduced or zero tillage, new harvest techniques, replenishment of nutrients, crop rotations), and

- the establishment of farming and ranching associations whose purposes are to address soil degradation problems.

Much remains to be done to reverse or mitigate the decades of loss and degradation of both upland and wetland habitats, soil quality, and water quality and flow patterns. Because of the scale of Parkland loss and the wide-ranging nature of most animal species adapted to the Parkland environment, "the recovery of many plant and animal species associated with native prairies will likely require management of large landscapes in ways other than full restoration to preagricultural conditions; specifically, in ways compatible with sustainable agriculture" (Anderson et al. 1995, p404-5). For endangered species, in particular, it is increasingly recognized that "future recovery efforts must be broadened to include public participation and emphasize ecosystembased management" (Dauphine 1996, p1).

Since farmers and ranchers often own much of the land in an area, they must be involved in any large-scale recovery, restoration or conservation initiatives. Although restoration of some private lands may be possible (e.g., marginal lands), "it is not reasonable to assume that many large tracts of productive privately owned agricultural lands can be retired from agricultural use" (ibid.). Baydack et al. $(1995, \mathrm{p} 395)$ suggest that "effective grassland conservation in the prairie landscape of Canada only can come about through revitalized rural communities supported by more diverse and stable income opportunities that are economically and environmentally sustainable."

Restoration of degraded habitats and landscapes will "require much more than just establishing protected areas" (Sinclair et al. 1995). For renewal,

"...it will be necessary to focus attention on combinations of activities, including protection and enhancement of native remnants, managed grazing systems, and sound soil and water conservation practices which should, collectively, provide for a more diverse, wildlife-friendly prairie landscape than exists over much of central North America today. There is a need to develop the means of providing new habitat in a 
wide range of situations and locations to offset the loss of original habitat" (ibid.).

Establishing protected areas, however, is an effective and practical tool that can be used to conserve ecosystems and species. Protected areas maintain ecosystems and populations of native species, and thus act as storehouses of irreplaceable genetic information. Apart from their invaluable role in the conservation of biodiversity, protected areas provide many other services and benefits (Hummel 1989; Nelson 1993). One of their most important functions is to serve as ecological benchmarks or "baselines", against which we can evaluate the quality of our management strategies for the vast majority of terrestrial and aquatic environments that lie outside such areas. In the coming millennium, protected areas could well constitute our lifelines to an ecologically and economically sustainable future.

The Alberta Government recognizes the need to protect the natural variety of Alberta's species and spaces within a system of protected areas. Implementing Alberta's Special Places initiative, announced March 28, 1995, is a key step.

The document Special Places 2000: Alberta's Natural Heritage -- Policy and Implementation Plan contains the Alberta government's Special Places 2000 policy statement, as follows:

"The Vision for Special Places 2000, Alberta's strategy, is to complete a network of Special Places that represent the environmental diversity of the province's six natural regions (20 Subregions) by the end of 1998" (Government of Alberta 1995, p5).

In addition to preserving Alberta's natural heritage, the Special Places policy has three other goals — outdoor recreation, heritage appreciation and tourism/economic development.

One of the seven guiding principles of Special Places 2000 is that: "the land classification system called Natural Regions (Subregions) and Natural History Themes provides the scientific basis for the identification, review and designation of Special Places." According to Alberta Environmental Protection (1994b), "the purpose of the natural regions' classification is to account for the entire range of natural landscape diversity in Alberta" and this scheme "best represents the ecosystem and biodiversity elements of importance to protected areas."

The next part of this report details the application of a land classification system in selecting a candidate protected areas network for Alberta's Parkland Natural Region. 



\section{PART 2}

\section{A Protected Areas Network for the Parkland Natural Region}





\section{Chapter 2.1 Designing a Protected Area's Network for the Parkland}

The following discussion has been taken primarily from the July 1996 report entitled, "Selecting Protected Areas: the Foothills Natural Region of Alberta" (Alberta Environmental Protection 1996).

\subsubsection{Theory}

By far the oldest and most familiar strategy for conserving Canada's landscapes, animals and plants is the establishment and management of parks, reserves or other forms of protected areas; but what is meant by the term "protected area?" Many definitions exist, but central to all officially accepted versions are three basic criteria: 1) the site must be legislated, 2) the protection of natural heritage values must be a fundamental reason for the site's establishment and, 3) management guidelines and monitoring programs must be instituted to ensure the site's long-term protection.

The United Nations "Brundtland Commission Report" (World Commission on Environment and Development 1987) defined protected areas as being "managed explicitly to conserve species and ecosystems." Genuine protected areas are managed so that: a) natural processes and forces are allowed to operate with minimal human interference and, b) all non-human forms of life can freely exercise their intrinsic right to exist for their own sakes. Because they preserve landscapes, ecosystems and habitats, protected areas play an increasingly vital role in the on-going effort to conserve Earth's biological diversity.

According to Cooperrider (1994), four fundamental objectives need to be pursued to maintain native biodiversity in perpetuity:

1. Represent in a system of protected areas all native ecosystem types and developmental stages across their natural range of variation.

2. Maintain viable populations of all native species in natural patterns of abundance and distribution.

3. Maintain ecological and evolutionary processes, such as disturbance regimes, hydrological processes, nutrient cycles and biotic interactions.

4. Manage landscapes and communities to be responsive to short-term and long-term environmental change, as well as to maintain the evolutionary potential of the biota.

With the advent of World Wildlife Fund (WWF) Canada's Endangered Spaces campaign and the subsequent signing of the Aylmer Declaration, the first of these objectives has been formally adopted by Canada's federal, provincial and territorial governments. They have committed to "make every effort to complete Canada's networks of protected areas representative of Canada's land-based natural regions by the year 2,000 ... " (pg. xiv in Hummel 1995). This commitment, with its emphasis on the "representativeness" of a reserve network, heralds a radical departure from past practices whereby protected areas tended to be selected for their uniqueness 
or rarity.

Reed Noss, one of the world's foremost conservation biologists, has summarized the legacy of our traditional rationale for protected area selection as follows: "our present system of reserves is far from ideal. National parks and other reserves in most parts of the world, including Canada, were selected to preserve spectacular scenery and provide recreational opportunities, while conflicting minimally with commodity production objectives (Noss and Cooperrider 1994)." Furthermore, "besides being an inadequate representation of Canada's natural diversity, existing parks and other reserves were poorly designed. Many are becoming ecological islands as surrounding lands are intensively developed" (Noss 1995, pp. 61-62).

However, over the last decade or so, major advances have been made in placing the selection and design of protected areas networks on a firmer, more rigorous, scientific footing (see, for example, Canadian Council on Ecological Areas 1992; Achuff and Wallis 1992; Lewis 1993; Noss and Cooperrider 1994; Kavanagh et al. 1995; and many others). Using two studies it commissioned (viz. Kavanagh et al. 1994, and Noss 1995, respectively), WWF Canada has developed "standard procedures" for: (a) the selection of representative protected areas based upon a gap analysis utilizing enduring features and, (b) the evaluation and employment of specific, reserve-network design criteria intended to maximize the probability that their component protected areas will maintain their ecological integrity over the long term. With their strongly Canadian perspective, these two recent publications are relevant to the Parkland's situation and are drawn upon extensively in the following account.

WWF Canada's gap analysis methodology is based initially on mapping natural regions and identifying the enduring features within them. By ensuring that representative examples of each natural region's enduring features are included within protected areas, it is hoped that its full range of biodiversity will also be represented. However, as exemplified by Kirkpatrick and Brown's (1994) comparison of the use of physical attributes versus biological data as protected area selection criteria in Tasmania, exclusive use of physical features can result in the omission of many rare species and communities. Noss (1995, p13), summarizing the results of this and analogous studies, cautions "final reserve selection decisions should not rely entirely on an enduring features gap analysis (since) critical biological elements would almost surely be missed."

Noss (1995) defines protected area networks as consisting of three integral components, i.e., highly protected core reserves, multiple-use buffer zones ( $c f$. Wells and Brandon, 1993) and linkages with other reserves (see, for example, Taylor et al. 1993, for a discussion of the importance of connectivity). To supplement the above-described gap analysis he recommends the use of various "additional criteria for selecting core areas." Employing Noss' criteria, WWF gives priority to the following kinds of sites (Kavanagh et al. 1995, p7):

1. Roadless, undeveloped, or otherwise essentially wild areas of significant size. Undeveloped areas, especially when they are less accessible to humans, or when they offer refuge to species sensitive to human activities.

2. Concentrations of rare species. These are obvious "hot spots" of biodiversity that should be included within reserves. 
3. Areas of unusually high species richness. These are areas where many different species can be protected efficiently.

4. Unusual plant or animal communities, forest succession stages (such as old-growth), or animal concentration areas such as bird or seal breeding sites; waterfowl staging areas; winter-range or calving grounds for caribou, moose, or elk; bear denning area (etc.).

5. Sites with unusual habitat conditions, such as artesian springs, ice-free bays, outcrops of unusual rocks or surface material, and mineral licks.

6. Watersheds of high value for fish or other aquatic life.

7. Sites that are sensitive to development, such as watersheds with steep slopes or unstable soils.

8. Sites recognized as important or sacred by aboriginal peoples.

9. Sites that could be added to existing protected areas to form larger areas with greater ecological integrity.

As stressed by Noss (1995), "representation of ecosystems is only the first step in the process of conserving biodiversity. Keeping species from extinction requires attention to reserve design issues that transcend representation." Maintaining the long-term ecological integrity of potential reserves is the second fundamental issue that governs the selection and design (and ultimate management) of candidate protected area sites. Noss $(1995, \mathrm{p} 1)$ outlines "three major objectives for maintaining ecological integrity in representative reserve networks," namely:

1. Sustain key geomorphological, hydrological, ecological, biological; and evolutionary processes within normal ranges of variation, while building a conservation network that is adaptable to a changing environment;

2. Maintain or restore viable populations of all native species in natural patterns of abundance and distribution; and

3. Encourage human uses that are compatible with the maintenance of ecological integrity."

For further discussion of the objectives listed above, see Kavanagh et al. (1995, p6-7). He also lists a series of conservation biology principles (some of which are useful aids to the reserve planning process) applicable to the maintenance of ecological integrity, including the following:

- Ecosystems are not only more complex than we think, but more complex than we can think (Egler 1977).

- The less data or more uncertainty involved, the more conservative a conservation plan must be (i.e., the more protection it must offer).

- Conservation biology is interdisciplinary, but biology must determine the bottom line (for instance, when conflicts with socioeconomic objectives occur).

- Species well distributed across their native range are less susceptible to extinction than species confined to small portions of their range.

- Large blocks of habitat, containing large populations of a target species, are superior to small blocks containing small populations.

- Blocks of habitat close together are better than blocks far apart (assuming no absolute barriers to dispersal lie between).

- Habitat in contiguous blocks is better than fragmented habitat. 
- Interconnected blocks of habitat are better than isolated blocks.

- Blocks of habitat that are roadless or otherwise inaccessible to humans are better than roaded and accessible habitats.

- Conservation strategy must not treat all species as equal but must focus on species and habitats threatened by human activities (Diamond 1976).

- Maintaining viable ecosystems is usually more efficient, economical, and effective than a species-by-species approach.

- Biodiversity is not distributed randomly or uniformly across the landscape. In establishing protection priorities, focus on "hot spots" of high species richness, endemism, or other biological or ecological values.

- Ecosystem boundaries should be determined by reference to ecology, not politics.

- Because conservation value varies across a regional landscape, zoning is a useful approach to land use planning and reserve network design.

- Ecosystem health and integrity depend on the maintenance of ecological processes.

- Human disturbances that mimic or simulate natural disturbances are less likely to threaten ecological integrity than are disturbances radically different from the natural regime.

- Ecosystem management requires cooperation between agencies and landowners and coordination of inventory, research, monitoring, and management activities.

- Management must be adaptive.

- Natural areas have a critical role to play as benchmarks or control areas for management experiments.

- $\quad$ "In the face of uncertainty over details, the prudent course is to risk erring on the side of protecting too much. Options for land conservation, once lost, cannot easily be regained" (Noss 1995, p4).

During the reserve design stage, consideration of the long-term maintenance of ecological integrity must take into account the threats posed by human activities "within, directly adjacent to, or between protected areas," since "it is well accepted that the integrity of a protected area becomes more difficult to maintain as the area surrounding it becomes less natural . ..." "Roads and other forms of access within or between protected areas can lead to losses of large carnivores and other species sensitive to human exploitation or persecution." And ... "as sensitive species are lost from a reserve or network of reserves, ecological integrity declines" (Noss 1995, p6).

Finally, Noss $(1995, \mathrm{p} 63)$ points out that

"Maintaining ecological integrity will seldom require complete exclusion of people over large areas. It is not so much people who need to be excluded from sensitive or biologically significant areas, but rather certain kinds of human activities Cactivities such as logging, road-building, mining, oil drilling, intensive livestock grazing, off-road vehicle use, dambuilding, and so on. In some areas, humting, trapping, and fishing will need to be prohibited. Although even non-motorized, non-consumptive recreationists can have damaging impacts when present in large numbers, in most cases access restrictions (no roads, limited trail systems) in core areas will keep these areas plenty wild." 


\subsubsection{Challenges}

Given the scope and depth of the environmental changes that have occurred in the Parkland Natural Region of Alberta, it may not be possible to achieve adequate representation of natural landscapes and features within protected areas. The pressures from the cumulative impacts of human activities have taken their toll. Protection opportunities, in some cases, have been lost (e.g., extinct species). In other cases, it may require new management approaches and initiatives to ensure that no additional opportunities are lost. A major challenge may well be the difficulty of maintaining, over the long term, a significantly large and contiguous land base within or outside of established protected areas, in which an area's biodiversity and associated natural ecological functions can continue.

A continuing challenge will be to protect key elements of the Parkland's biological diversity (e.g., species, critical and special habitats, biophysical features). Some species have extensive habitat requirements that will be difficult to capture within a network of protected areas. Establishing "special places", however, can make a significant contribution to the conservation of species and maintenance of biodiversity. The establishment of protected areas that encompass critical habitats of key species would assist in the conservation of those species.

Protecting an adequate representation of an area's landscapes and features is just one part of protecting its biodiversity. As Grumbine $(1992, \mathrm{p} 195)$ states, "there can be no biodiversityprotection network without a sustainable landscape of use as well." The landscape in which protected areas are "embedded" must also be used and conserved according to the principles of ecosystem-based management (e.g., Slocombe 1993; USDA 1993). As Grumbine expresses it, this will involve "both working with nature and letting it be; it is hands on as well as hands off."

Ecosystem-based management "does not presume to manage all components of the ecosystem, but rather to manage our activities so that overall ecosystem integrity is maintained, biodiversity is preserved and an ecologically sustainable flow of benefits is achieved." This "involves a shift in management focus from sustaining yields of competing resource outputs to sustaining ecosystems" (Bradley and Wallis 1996, p22). These authors present four key principles of ecosystem-based management for the Grassland and Parkland Natural Regions, namely:

- maintaining and restoring native Grassland and Parkland so society can derive and sustain all the benefits that flow from it (ecological, economic and social);

- attempting to perpetuate and approximate natural factors and processes;

- applying ecological knowledge to Grassland and Parkland management, monitoring the results and adapting as required; and

- recognizing multidisciplinary and interjurisdictional needs.

As Bradley and Wallis (ibid., p25) summarize,

"...adopting these principles of ecosystem-based management could have far-reaching implications for how we manage and live in the prairie; indeed, it could affect how we think about and understand our place in the prairie ecosystem. It will reflect a shift in values away from controlling or living separate from our natural environment to respecting and living 
within it. Our decisions as individuals and communities in the prairie will determine how successful we are at managing our activities so that overall ecosystem integrity is maintained, biodiversity is preserved and an ecologically sustainable flow of benefits is achieved."

\section{Chapter 2.2 Identifying the Gaps in the System of Protected Lands in Alberta}

\subsubsection{The Natural History Theme Approach}

The Natural History Theme approach is a three-level classification of the natural history features found within each of Alberta's 20 Subregions. The features are sorted into Level 1, 2 and 3 "Natural History Themes" [NHTs]. Level 1 NHTs are the broad, representative landscape types and patterns found within a Subregion. They represent highly visible landform and ecosystem complexes, typically occupying more than $1 \%$ of the landscape. Level 1 NHTs can be further sub-divided into Level 2 and 3 NHTs. Level 2 NHTs are primarily the broad vegetation and habitat types characteristic of the Subregion. Level 3 NHTs are generally localized features such as geologic outcrops, rock formations, plant communities, individual species and microhabitats for uncommon species (Alberta Environmental Protection [AEP] 1994b).

As part of the Special Places 2000 initiative, targets have been established for each of the Level 1 NHTs in each Subregion (ibid.). These targets are a "best educated guess" on the amount of land $\left(\right.$ in $\mathrm{km}^{2}$ ) required to adequately represent the natural diversity contained within each NHT. It is assumed that a representative sample of the biophysical features will be protected if a representative portion of the landscapes in which they are found is protected.

Guidelines set out by AEP (ibid., p2) regarding the size and number of protected areas required to achieve adequate representation of Level 1 NHTs are as follows:

- unless a protected area is large relative to the size of the Subregion, more than one area will be required to achieve adequate representation. These replicates serve to cover off some of the geographic variation within Subregions.

- in addition to meeting the target area requirement, the NHT should be well-represented in more than $\mathbf{5}$ widely spaced small units meeting the minimum size criteria of $10 \mathrm{~km}^{2}$, or more than $\mathbf{2}$ widely spaced large units greatly exceeding the minimum size criteria.

These targets are only for protection objectives; they are "based on the assumption that lands specified for meeting those targets will have a prime function in ecosystem protection and will not be subject to significant recreation and tourism use" (ibid., p2).

According to the Canadian Environmental Advisory Council (1991) as paraphrased in Report 3 (AEP 1994b, p2) "Large wilderness areas in the order of $4000 \mathrm{~km}^{2}$ and larger are recommended for complete biodiversity and wilderness protection." Report 3 states: "Level 1 Theme targets indicate a desired area of protection that will be adequate to represent a considerable portion of Alberta's natural diversity additional lands and management approaches are needed to adequately protect the full range of Alberta's natural diversity." 
The NHT system is a type of gap analysis; it provides a way of determining which features are not yet included or not adequately represented within existing protected areas. It also facilitates the comparison of sites within (but not between) Subregions. This is important for evaluating and comparing areas for their potential contribution toward filling the gaps in the system of protected areas. Gap analyses have been completed for each of the province's natural regions for Level 1 NHTs (ibid., see Chapter 1 of that report). Gaps may be filled via the creation of new protected areas or, in some instances, by the expansion and/or reclassification of existing protected areas.

Landscapes of the Parkland Natural Region have been significantly altered. It is one of the least protected regions in Alberta (ibid.). As Table 9 illustrates, minimal representation of the Level 1 NHT targets has been achieved for any of the Parkland Subregions.

\begin{tabular}{|c|c|c|c|c|}
\hline Subregion & $\begin{array}{l}\text { Area }\left(\mathrm{km}^{2}\right) \text { of } \\
\text { Subregion }\end{array}$ & $\begin{array}{l}\text { Area }\left(\mathrm{km}^{2}\right) \text { of } \\
\text { Level } 1 \text { target }\end{array}$ & $\begin{array}{c}\% \text { of Level } 1 \\
\text { minimum target } \\
\text { achieved }\end{array}$ & $\begin{array}{c}\% \text { of } \\
\text { Subregion } \\
\text { protected }\end{array}$ \\
\hline Central Parkland & 53413 & 1417.5 & 4 & .1 \\
\hline $\begin{array}{l}\text { Foothills } \\
\text { Parkland }\end{array}$ & 4402 & 227.5 & 0 & 0 \\
\hline $\begin{array}{l}\text { Peace River } \\
\text { Parkland }\end{array}$ & 4665 & 150 & 0 & 0 \\
\hline \multicolumn{5}{|c|}{$\begin{array}{l}\text { *Protected areas less than } 10 \mathrm{~km}^{2} \text { in size were not included in these calculations since they do } \\
\text { not meet the minimum size criteria of } 10 \mathrm{~km}^{2} \text {. For more detail on the contribution each of the } \\
\text { NHTs makes toward achieving the targets within the three Subregions, refer to Tables } 12 \text { to } \\
14 \text { in this report. }\end{array}$} \\
\hline
\end{tabular}

\subsubsection{Special Themes}

Special themes are included in the NHT tables for each Subregion "to ensure that all aspects of natural diversity are addressed" (Achuff and Wallis 1992, p6). In the Parkland, they are generally not significant until Level 2 or 3 . Special themes "relate to features that are unique or atypical, characteristically occupying very limited areas of the landscape" (ibid.). Although several Special Themes are listed in the NHT tables, "a detailed evaluation and identification of Special Themes has never been done for Alberta" (ibid.). Those identified for the Parkland Subregions are listed in Table 10. The focus of this report is achieving landscape representation through meeting targets for Level 1 NHTs. Sites that include recognized Special Themes will be noted. 


\begin{tabular}{|l|l|}
\hline Table 10.Examples of Special Themes in the Parkland Natural Region (AEP 1994b). \\
\hline Central Parkland & Beaverhill Lake \\
\cline { 2 - 2 } & Ice-Thrust Ridge \\
\cline { 2 - 2 } & Reflex Lake \\
\cline { 2 - 2 } & Sounding Lake \\
\cline { 2 - 2 } & David Lake Fen-Beaver Pond Complex \\
\cline { 2 - 2 } & David Lake Slope Fen \\
\hline & Glacial Megablock \\
\cline { 2 - 2 } & Glacial Streamlined Terrain \\
\cline { 2 - 2 } & $\begin{array}{l}\text { Gwynne Outlet-Battle River Glacial } \\
\text { Spillway }\end{array}$ \\
\cline { 2 - 2 } & Esker Field \\
\cline { 2 - 2 } & Buried Channel \\
\cline { 2 - 2 } & Lousana Canyon \\
\hline Foothills Parkland & Foothills Erratics Train \\
\cline { 2 - 2 } & Carway Iris \\
\hline Peace River Parkland & Kleskun Hill \\
\hline
\end{tabular}

\subsubsection{Special Features}

To maintain the biodiversity of a natural region, it is necessary to identify and protect both the broad representative landscapes (i.e., Level 1 NHTs) as well as the smaller and more localized special features. It is important not only to achieve representation of Level 1 NHTs within established protected areas, but also to attempt to select those NHTs that have a diversity of high quality special features within them. Relying on landscape features alone may result in the omission or rare species and communities.

\subsubsection{Enduring Features}

The Enduring Features approach is similar to the Alberta Natural History Theme approach. This is a gap analysis methodology used for the World Wildlife Fund Canada's "Endangered Spaces" campaign. A discussion on this approach follows as it is the approach used nationally and is comparable with the Alberta approach. It is based initially on mapping natural regions and identifying enduring features within them. An enduring feature is "a landscape element or unit characterized by relatively uniform origin and type of surficial deposits and topography" (Kavanagh et al. 1995).

As summarized in Alberta Environmental Protection (1996, p44):

"The use of enduring features. . . 'assumes that habitats defined by soils, parent materials, topography and other physical factors provide the appropriate framework to assess representation of landforms and their associated biotic features' (Noss 1995, p13). In addition, 'to capture biological diversity, the full array of physical habitats and environmental gradients associated with each enduring feature must be represented in protected areas' (Kavanagh et al. 1994, p34)... 
'Once all enduring features of a given natural region are identified, comparison with the boundaries of existing protected areas reveals which features are not represented within the reserves network. As described by Kavanagh et al. (1995), 'These unrepresented enduring features are the 'gaps' in the system. A 'gap analysis', therefore, shows where there is insufficient protection of enduring features and ecological communities in existing protected-areas systems'."

An analysis of the ecological representation of enduring features within protected areas rated Alberta's Parkland Region as having "little or no representation" (WWF 1996). This level of representation is defined as follows: "None of the major enduring features are moderately or adequately captured and less than $80 \%$ of features are partially captured" (ibid., p27).

The Enduring Feature's methodology is based on "the assumption that ecological diversity (and hence, biodiversity) is largely an expression of abiotic factors such as climate, physiography, topography, and surface geology interacting over time." Level 1 NHTs are also primarily landscape types; however, they consist of a "complex of physical and biological features" (Achuff 1992, p5). An important difference then between the Level 1 NHTs and the Enduring Features is that Level 1 NHTs include a consideration of the biotic component.

Another difference is that of scale. Enduring features are groupings of soil polygons from the Soil Landscapes of Canada digital database mapped at a scale of 1:1,000,000 (AAFC 1995). Level 1 NHTs are defined based on available data. This often includes the use of surficial geology maps, soil maps and aerial photography. Scales vary, but are generally 1:250,000 or larger. Because both systems look generally at landscape features, there are similarities between the Level 1 NHTs and the soil landscape polygons. The soil polygons, however, are mapped at a coarser scale than the Level 1 NHTs. For example, Valley/Ridge areas can be easily identified from a map, but specific Level 1 NHTs for that category (exposed and protected slope, springs and floor/stream) cannot be identified. In addition, two themes may be grouped within a single polygon as dominant and subdominant soil landscapes, making it difficult or impossible to differentiate them.

The two methodologies, although not entirely comparable, are compatible. The Level 1 NHTs that are primarily abiotic (landscape and soils), match with the enduring features. Themes like springs that are given Level 1 NHT status due primarily to their biotic importance, are embedded within enduring features.

According to Kavanagh (op. cit., p47), enduring features are assessed for their level of representation based on:

- the spatial extent, pattern, variability and distribution of each enduring feature in a natural region,

- the extent that the enduring feature is captured within existing protected areas,

- the long-term security afforded the enduring feature by the existing protected area legal designation, and

- characteristics (size and frequency) of important disturbance-recovery cycles.

The WWF approach "intentionally moves away from an emphasis on percentage as a criterion for representation in order to focus on natural processes" (Kavanagh et al. 1995, p47). The example 
given is that for some community types, "a larger area would be required to maintain the range of ... community variation and associated disturbance regimes" (ibid., p47). Although measurable size targets were set for Level 1 NHTs, the differences in the various communities were considered. Targets were set based on "the importance of various Themes to natural diversity representation as well as the areal extent of those Themes in the landscape of each Subregion" (Achuff 1992, p8). WWF, while stressing that "ecological representation, not percentage, is the Endangered Spaces Campaign goal," notes that achieving the goal to protect "...a representative sample of each of the country's terrestrial natural regions... will likely involve setting aside at least $12 \%$ of Canada's lands" (WWF 1996, p24).

\subsubsection{Existing Protected Areas in the Parkland Natural Region}

"Protected Areas" are defined by Alberta Environmental Protection as sites that are "explicitly legislated and managed to protect important natural features" (AEP 1994b). These sites include crown lands that are established as national parks, national wildlife areas, wilderness areas, wilderness parks, ecological reserves, provincial parks and natural areas. The protected areas established within the Parkland Natural Region are listed in Table 11. As noted in the table, some sites straddle Subregion borders, and so only a portion of the site falls within a particular Subregion. Several sites are smaller than the minimum size criteria of $10 \mathrm{~km}^{2}$ for contributing to representation of Level 1 NHTs, and so are not included in Table 11.

\begin{tabular}{|c|c|c|c|}
\hline Subregion & Site & $\begin{array}{c}\text { Size } \\
\left(\mathrm{km}^{2}\right)\end{array}$ & Comments \\
\hline \multirow[t]{3}{*}{$\begin{array}{l}\text { Central } \\
\text { Parkland }\end{array}$} & $\begin{array}{l}\text { Rumsey South Natural } \\
\text { Area* }\end{array}$ & 149.22 & $144.3 \mathrm{~km}^{2}$ in Northern Fescue Subregion \\
\hline & Rumsey Ecological Reserve & 34.32 & $4.3 \mathrm{~km}^{2}$ in Northern Fescue Subregion \\
\hline & $\begin{array}{l}\text { Wainwright Dunes } \\
\text { Ecological Reserve }\end{array}$ & 28.76 & \\
\hline $\begin{array}{l}\text { Foothills } \\
\text { Parkland } \\
\end{array}$ & $\mathrm{n} / \mathrm{a}$ & $\bar{n} / \mathrm{a}$ & - no site meets $10 \mathrm{~km}^{2}$ size criteria \\
\hline $\begin{array}{l}\text { Peace River } \\
\text { Parkland }\end{array}$ & $\mathrm{n} / \mathrm{a}$ & $\mathrm{n} / \mathrm{a}$ & - no site larger than $10 \mathrm{~km}^{2}$ \\
\hline
\end{tabular}

Although only 4.9 sq. km of Rumsey South are in the Central Parkland, it is contiguous with Rumsey Ecological Reserve and so together they contribute to Level 1Themes.

\subsubsection{Representation of Level 1 Natural History Themes in Existing Protected Areas}

In Alberta Protected Areas Systems Analysis, Report 3 (AEP 1994b), the estimated aerial extent of Level 1 NHTs (in $\mathrm{km}^{2}$ ) is presented for existing protected areas within each of the three Parkland Subregions. Those aerial extent figures, however, were based on the entire land base of each protected area. Developments such as parking lots, roads or townsites were included and counted as contributing to protection targets in these initial estimates, when clearly they do not. 
For this report, estimates of the Level 1 NHTs targets within established protected areas have been revised to exclude developments and associated impacted areas. Sites with an area of less than $10 \mathrm{~km}^{2}$ were not evaluated since they do not make significant contributions to the protection of representative landscapes. They may, however, protect significant Level 2 or Level 3 NHTs. The following discussion briefly outlines the extent to which the Level 1 NHTs are represented and the major gaps remaining in each of the Parkland Subregions.

\section{Central Parkland Subregion}

\section{Representation within existing protected areas:}

Two protected areas greater than $10 \mathrm{~km}^{2}$ are located within the Central Parkland Subregion, the Wainwright Ecological Reserve and about $30 \mathrm{sq}$. $\mathrm{km}$ of the Rumsey Ecological Reserve. Almost 5 sq. km of the Rumsey South Natural Area are within the Central Parkland and are included here because lands are contiguous with the Rumsey Ecological Reserve. Together, these sites contribute to meeting between $0 \%$ to $48 \%$ of the Level 1 NHT targets for this Subregion (Table 12).

No targets have been met for the thirteen Level 1 NHTs. Two Level 1 NHTs are greater than $40 \%$ achieved: wetland:wet meadow (48\%) and wetland:shallow marsh (44\%). The remaining eleven Level 1 NHTs have less than $30 \%$ of their targets achieved and, of those, seven have no representation (Table 12).

\section{Gaps to be filled:}

In the Central Parkland Subregion, there are major gaps for all Level 1 NHT targets. All of the existing representation comes from sites located in the eastern portion of the Subregion. There is no representation from the northern portion. Within this Subregion, there is no representation for seven Level 1 NHTs (Table 12). To meet the target of at least $147.5 \mathrm{~km}^{2}$ for this Subregion, an additional minimum of $1359 \mathrm{~km}^{2}$ of land, containing representation of all Natural History Themes, is required (Table 12). 


\section{Foothills Parkland Subregion}

\section{Representation within existing protected areas:}

There is no protected area greater than $10 \mathrm{~km}^{2}$ in size that has at least a major portion of its area within the Foothills Parkland Subregion. Fish Creek Provincial Park lies partially within the Subregion. Fish Creek is a developed urban park and is fragmented by trails, parking lots, dayuse areas, etc. The Cross Conservation Area also lies within the Subregion but has considerable area in non-native vegetation. Once these factors are considered, both sites are too small to contribute to the Foothills Parkland themes.

\section{Gaps to be filled:}

A summary of the Level 1 NHTs and targets for the subregion is printed in Table 13. There are major gaps in the Level 1 NHT representation for this Subregion. No targets have been achieved. All Level 1 NHTs have no representation.

\section{Table 13. Level 1 NHT Theme Summary for the Foothills Parkland Subregion.}

\begin{tabular}{|l|c|}
\hline \multicolumn{1}{|c|}{ Theme } & Target $\left(\mathrm{km}^{2}\right)$ \\
\hline Non-Sandy Upland: glacial lake bed & 25 \\
\hline Non-Sandy Upland: ground moraine & 100 \\
\hline Valley/Ridge: exposed slope & 10 \\
\hline Valley/Ridge: protected slope & 10 \\
\hline Valley/Ridge: floor/stream & 25 \\
\hline Valley/Ridge: ridge/valley wall & 25 \\
\hline Valley/Ridge: springs & 2.5 \\
\hline Wetland: wet meadow & 10 \\
\hline Wetland: shallow marsh & 10 \\
\hline Wetland: deep marsh & 10 \\
\hline Totals: $*$ & 227.5 \\
\hline Size of Subregion (km ${ }^{2}$ ) & 4402 \\
\hline Level 1 Target as \% of the Subregion & $5.2 \%$ \\
\hline Level 1 Representation as \% of the Subregion & 0 \\
\hline $\begin{array}{l}\text { NOTE: Level 1 NHTs are only calculated for those protected areas within the Subregion that } \\
\text { exceed the minimum size criteria of } 10 \mathrm{~km}^{2} .\end{array}$ \\
$\begin{array}{l}\text { * Although totals are given here, it is important to keep in mind that each Level 1 NHT is } \\
\text { distinct and the targets should be met for each. }\end{array}$ \\
\hline
\end{tabular}




\section{Peace River Parkland Subregion}

\section{Representation within existing protected areas:}

The Peace River Parkland has no protected areas greater than $10 \mathrm{~km}^{2}$ in size within its boundaries.

\section{Gaps to be filled:}

A summary of the Level 1 NHTs and targets for the subreqion is provided in Table 14 . There are major gaps in the Level 1 NHT representation for this Subregion. No targets have been achieved. All Level 1 NHTs have no representation.

\section{Table 14. Level 1 NHT Theme Summary for the Peace River Parkland Subregion}

\begin{tabular}{|l|c|}
\hline \multicolumn{1}{|c|}{ Theme } & Target $\left(\mathrm{km}^{2}\right)$ \\
\hline Non-Sandy Upland: glacial lake bed & 100 \\
\hline Valley/Ridge: exposed slope & 25 \\
\hline Valley/Ridge: protected slope & 10 \\
\hline Valley/Ridge: floor/stream & 10 \\
\hline Wetland: wet meadow & 10 \\
\hline Wetland: shallow marsh & 10 \\
\hline Wetland: deep marsh & 10 \\
\hline Wetland: lake & 10 \\
\hline Totals: ** & 185 \\
\hline Size of Subregion $\left(\mathrm{km}^{2}\right)$ & 4665 \\
\hline Level 1 Target as \% of the Subregion & $4.0 \%$ \\
\hline Level 1 Representation as \% of the Subregion & 0 \\
\hline $\begin{array}{l}\text { NOTE: Level 1 NHTs are only calculated for those protected areas within the Subregion that } \\
\text { exceeded the minimum size criteria of } 10 \mathrm{~km}^{2} .\end{array}$ \\
*Although totals are given here, it is important to keep in mind that each Level 1 NHT is distinct \\
and the targets should be met for each.
\end{tabular}

\section{Chapter 2.3 Filling the Gaps in the System of Protected Lands in Alberta's Parkland}

Once the gaps in the system of protected areas are identified, the next step is to find sites to fill those gaps. In the Parkland Natural Region, all of the Level 1 Natural History Theme targets have yet to be achieved. To help focus on areas that have the potential to contribute to representation of missing themes, there are several studies and sources of information available. These include Environmentally Significant Area (ESA) studies and digital databases, the Soil Landscapes of Canada database (Shields and Lindsay 1990), a number of overview biophysical studies, and interpretation of National Topographic Series and Surficial Geology maps and aerial photographs. The current focus is towards achieving landscape representation through meeting 
targets for Level 1 NHT, however, relying on landscape features alone may result in the omission of rare species and communities. Any known special features or special themes are therefore noted throughout the discussions.

\subsubsection{Environmentally Significant Areas}

Bentz et al. (1995, p6) define Environmentally Significant Areas (ESAs) as: "landscape elements or places which are vital to the long-term maintenance of biological diversity, soil, water or other natural processes, both on-site and in a regional context." They also characterize ESAs as "important, unique and often sensitive features of the landscape." ESAs include features such as critical wildlife habitats, rare and endangered flora and fauna, unique geological or physiographic features, representative landscapes and remnants of formerly intact ecosystems.

Several studies have been conducted within the Parkland Natural Region that identify ESAs (Table 15). These studies were originally intended as planning tools for municipal governments. There are 101 ESAs of provincial and higher significance that have been identified within the Parkland Natural Region (Table 16). Of these, seven are internationally significant, 35 nationally significant and 61 provincially significant. Those ESAs of provincial and higher significance occupy a combined area of about $4651 \mathrm{~km}^{2}$ or about $7.5 \%$ of the Parkland Natural Region (Table 16). The largest ESAs range in size from $67 \mathrm{~km}^{2}$ in the Peace River Parkland to $650 \mathrm{~km}^{2}$ in the Foothills Parkland.

Most ESAs contain special features and special themes. Many of these are listed in the following three chapters under each of the sites that are discussed. Some sites have been more intensively studied than others and, therefore, the lists vary in their completeness. These lists will aid in selecting sites that are recognized for their diversity. Although a number of special features are located within established protected areas, many are not. Additional lands and different management approaches may, therefore, be required to adequately protect these features, or existing protected area boundaries may need to be modified. 


\begin{tabular}{|c|c|}
\hline $\begin{array}{l}\text { Location of } \\
\text { Study }\end{array}$ & Author \\
\hline Calgary Region & $\begin{array}{l}\text { Lamoureux, R. G. Chow and B. Reeves. 1983. Environmentally significant areas of } \\
\text { the Calgary region. Prepared for Calgary Regional Planning Commission, Calgary. }\end{array}$ \\
\hline M.D. of Cardston & $\begin{array}{l}\text { Cottonwood Consultants Ltd. 1987b. Environmentally significant areas in the } \\
\text { Oldman River Region: M.D. of Cardston. Prepared for Alberta Forestry, Lands and } \\
\text { Wildlife. }\end{array}$ \\
\hline $\begin{array}{l}\text { Counties of } \\
\text { Lacombe and } \\
\text { Stettler }\end{array}$ & $\begin{array}{l}\text { Sweetgrass Consultants Ltd. 1988. Environmentally significant areas of the } \\
\text { Counties of Lacombe and Stettler. Prepared for the Red Deer Regional Planning } \\
\text { Commission, Red Deer. }\end{array}$ \\
\hline County of Leduc & $\begin{array}{l}\text { Brusnyk, L., D. Westworth, K. Egan, A. McCann, L. Knapik and C. Schreiner. } \\
\text { 1991. Environmentally sensitive areas study: County of Leduc. Prepared for the } \\
\text { Edmonton Metropolitan Regional Planning Commission, Edmonton. }\end{array}$ \\
\hline $\begin{array}{l}\text { County of Red } \\
\text { Deer }\end{array}$ & $\begin{array}{l}\text { Sweetgrass Consultants Ltd. 1990. Environmentally significant areas of the County } \\
\text { of Red Deer. Prepared by Sweetgrass Consultants, Calgary, for the Red Deer } \\
\text { Regional Planning Commission, Red Deer. }\end{array}$ \\
\hline $\begin{array}{l}\text { County of } \\
\text { Mountain View }\end{array}$ & $\begin{array}{l}\text { Sweetgrass Consultants Ltd. 1991. Environmentally significant areas of the County } \\
\text { of Mountain View. Prepared for Alberta Forestry, Lands and Wildlife. }\end{array}$ \\
\hline $\begin{array}{l}\text { County of } \\
\text { Paintearth }\end{array}$ & $\begin{array}{l}\text { Sweetgrass Consultants Ltd. 1989. Environmentally significant areas of the County } \\
\text { of Paintearth. Prepared for the Red Deer Regional Planning Commission, Red Deer. }\end{array}$ \\
\hline $\begin{array}{l}\text { County of } \\
\text { Strathcona and } \\
\text { MD of Sturgeon }\end{array}$ & $\begin{array}{l}\text { Westworth, D. and L. Knapik. 1987. Significant natural features and landscapes of } \\
\text { Strathcona County. Prepared for Recreation and Parks, Strathcona County. } \\
\text { and } \\
\text { Infotech. 1989. Environmentally sensitive areas: County of Strathcona and MD of } \\
\text { Sturgeon. Prepared for the Edmonton Metropolitan Regional Planning Commission, } \\
\text { Edmonton. }\end{array}$ \\
\hline $\begin{array}{l}\text { M.D. of Pincher } \\
\text { Creek }\end{array}$ & $\begin{array}{l}\text { Cottonwood Consultants Ltd. 1987a. Environmentally significant areas in the } \\
\text { Oldman River Region: MD of Pincher Creek. Prepared for the Oldman River } \\
\text { Regional Planning Commission, Lethbridge. }\end{array}$ \\
\hline $\begin{array}{l}\text { Remainder of } \\
\text { Central and } \\
\text { Peace River } \\
\text { Parkland not } \\
\text { covered by other } \\
\text { studies }\end{array}$ & $\begin{array}{l}\text { Saxena, A., V. Chisholm and J. Bentz. 1996. Environmentally significant areas } \\
\text { inventory, Grassland and Parkland Natural Regions, Alberta. Prepared for Resource } \\
\text { Data Division, Alberta Environmental Protection, Edmonton. } \\
\text { and } \\
\text { Cottonwood Consultants Ltd. 1995. Environmentally significant areas of the } \\
\text { Lloydminster Area. Alberta and Saskatchewan. Prepared for Nature Conservancy of } \\
\text { Canada and Husky Oil Operations. Calgary. } \\
\text { and } \\
\text { Wallis, C. 1990. Reconnaissance survey of saline wetlands and springs in the } \\
\text { grassland-parkland region of eastern Alberta. Prepared for World Wildlife Fund, } \\
\text { Edmonton. }\end{array}$ \\
\hline
\end{tabular}




\begin{tabular}{|c|c|c|c|c|c|c|c|c|}
\hline \multirow{2}{*}{$\begin{array}{l}\text { ESA } \\
\text { Significance } \\
\text { Rating }\end{array}$} & \multicolumn{2}{|c|}{$\begin{array}{l}\text { Central } \\
\text { Parkland }\end{array}$} & \multicolumn{2}{|c|}{$\begin{array}{l}\text { Foothills } \\
\text { Parkland }\end{array}$} & \multicolumn{2}{|c|}{$\begin{array}{l}\text { Peace River } \\
\text { Parkland }\end{array}$} & \multicolumn{2}{|c|}{ Total } \\
\hline & $\begin{array}{c}\text { Size } \\
\left(\mathrm{km}^{2}\right)\end{array}$ & $\begin{array}{l}\text { No. } \\
\text { ESAs }\end{array}$ & $\begin{array}{c}\text { Size } \\
\left(\mathrm{km}^{2}\right)\end{array}$ & $\begin{array}{c}\text { No. } \\
\text { ESAs }\end{array}$ & $\begin{array}{c}\text { Size } \\
\left(\mathrm{km}^{2}\right)\end{array}$ & $\begin{array}{c}\text { No. } \\
\text { ESAs }\end{array}$ & $\begin{array}{c}\text { Size } \\
\left(\mathrm{km}^{2}\right)\end{array}$ & $\begin{array}{c}\text { No. } \\
\text { ESAs }\end{array}$ \\
\hline International & 457 & 6 & .1 & 1 & 0 & 0 & 457 & 7 \\
\hline National & 1832 & 26 & 742 & 2 & 43 & 7 & 2617 & 35 \\
\hline Provincial & 1224 & 39 & 191 & 15 & 181 & 7 & 1583 & 61 \\
\hline TOTAL & 3513 & 71 & 933 & 15 & 224 & 14 & 4657 & 101 \\
\hline $\begin{array}{l}\text { Subregion size } \\
\left(\mathrm{km}^{2}\right)\end{array}$ & \multicolumn{2}{|c|}{53413} & \multicolumn{2}{|c|}{4402} & \multicolumn{2}{|c|}{4665} & \multicolumn{2}{|c|}{62480} \\
\hline $\begin{array}{l}\text { Proportion of } \\
\text { Subregion } \\
\text { occupied by } \\
\text { ESAs }(\%)^{*}\end{array}$ & \multicolumn{2}{|c|}{6.6} & \multicolumn{2}{|c|}{21.2} & \multicolumn{2}{|c|}{4.8} & \multicolumn{2}{|c|}{7.5} \\
\hline $\begin{array}{l}\text { Largest ESA } \\
\left(\mathrm{km}^{2}\right)^{*}\end{array}$ & \multicolumn{2}{|c|}{569} & \multicolumn{2}{|c|}{640} & \multicolumn{2}{|c|}{67} & \multicolumn{2}{|c|}{640} \\
\hline
\end{tabular}

\subsubsection{Digital Coverages}

Given the level of development in the Parkland Natural Region, an important step in identifying the best potential protected areas in the region involved what could be termed an "inverse gap analysis" (i.e., determining what is left). On a Subregion by Subregion basis, potential sites were identified by screening to ensure that criteria, as listed below, were met.

Only provincial crown lands (Table 17) were considered as having potential to contribute to a provincially-legislated protected area. These were determined by land ownership digital coverage:

- Provides information on the distribution of private, provincial crown and federal crown land (e.g., Indian reserves) in the area.

- Derived by combining a quarter-section ARC/INFO GIS positional file for Alberta (accuracy to $5 \mathrm{~m}$ ) with land ownership attribute data.

- Land ownership attribute data is by quarter-section from LSAS. The Land Status Automated System is the official government database of the status of lands in Alberta including township information and any dispositions registered against those lands.

- Accurately identifies quarter-sections that are entirely crown or entirely freehold.

- Quarter-sections listed as "mixed" may be almost entirely crown, almost entirely freehold or some combination. Further queries of LSAS would be required to learn their exact status. 
These should be checked for Crown land inclusions for potential inclusion in nominated sites.

- Quarter-sections listed as "other" had an unknown ownership status at the time of the LSAS data exchange.

- The "water" areas are all waterbodies $1.5 \mathrm{~km}^{2}$ or larger as taken from 1:250,000 map data hydrology coverage.

\begin{tabular}{|c|c|c|c|c|c|c|c|c|c|}
\hline Sub-region & Crown & Freehold & Mixed & Other & Water & \begin{tabular}{|c|} 
Indian \\
Reserves
\end{tabular} & \begin{tabular}{|l|} 
Military \\
Reserves
\end{tabular} & $\begin{array}{l}\text { Urban } \\
\text { Areas }\end{array}$ & \begin{tabular}{|c|} 
TOTAL \\
km $^{2}$
\end{tabular} \\
\hline $\begin{array}{l}\text { Central } \\
\end{array}$ & 2725 & 49300 & 878 & 144 & 316 & 409 & 647 & 1192 & 55611 \\
\hline \begin{tabular}{|l|} 
Foothills \\
\end{tabular} & 949 & 3326 & 127 & 1 & 0 & 181 & 6 & 302 & 4892 \\
\hline Peace River & 511 & 3960 & 90 & 82 & 21 & 6 & 0 & 79 & 4749 \\
\hline Total $*\left(\mathrm{~km}^{2}\right)$ & 4186 & 56585 & 1095 & 227 & 337 & 596 & 653 & 1573 & 65252 \\
\hline
\end{tabular}

Urban developments (Table 17) were excluded from consideration as having potential to contribute to representation of Level 1 NHTs. These were determined by cities and towns digital coverage:

- Derived by converting digital 1:250,000 scale Provincial Mapping Series (Microstation Files) to ARC/INFO GIS format.

High road densities decrease the quality of a site for its contribution to representation of Level 1 NHTs. These were determined by road digital coverage:

- Derived by converting digital 1:250,000 scale Provincial Mapping Series (Microstation Files) to ARC/INFO GIS format.

- Road densities derived by intersecting the road network with townships and Subregions.

- Road data was then summarized by unique township/Subregion polygons and densities calculated.

High densities of wellsites decrease the quality of a site for its contribution to representation of NHTs. These were determined by petroleum and natural gas wellsite digital coverage:

- Provides information on the distribution and density of wellsites in an area.

- Point data supplied by Alberta Energy and converted to ARC/INFO GIS format.

- Data shows bottom-hole location, which is usually but not always the same as the surface wellsite location (i.e., non-deviated boreholes).

- Includes all wells on record (i.e., dry, producing, abandoned, etc.).

ESAs ranked as provincially, nationally or internationally significant were considered as having potential, as determined by $\underline{E S A}$ digital coverage:

- Compiled from the series of ESA reports done for the province

- Digitized from the original report maps, with scales generally between 1:50,000 and $1: 250,000$

- Ranking and criteria have evolved since the first ESA study in Alberta was done for the 
Calgary region (Lamourex et al. 1983)

- Digital data and rankings were updated for those ESAs ranked as provincially, nationally or internationally significant (ANHIC 1997).

Using combinations of the digital coverages listed above, each Parkland Subregion was evaluated to identify sites that are of the most value for conservation. These are outlined on Map 2 - Blocks for evaluation. Only sites on provincial crown land were considered as potential protected areas. These are the only lands available for inclusion in the provincially-legislated protected area's network.

\subsubsection{Central Parkland Subregion}

The Aspen Parkland is a highly modified ecosystem. Processes that maintain parkland vegetation are no longer in place or are heavily modified. Fires are suppressed and forest and shrub encroachment is ongoing. Cattle grazing is variable and its role in "natural" pre-European contact Parkland is poorly understood. There has been extensive invasion by non-native plant species. Major predators such as wolves and grizzly bears no longer a functional part of ecosystem. Ongoing clearing, planting to tame species, fragmentation by roads, and oil and gas development limit the protected area opportunities.

"Natural" parkland exists only as fragments. The significant opportunities for theme representation in protected areas are found mainly on Public Land. Private lands are more intensively used and most have been converted to non-native species. There are opportunities for maintaining large blocks of Aspen Parkland and improving connectivity in sand plain areas and river valleys. There is very little land base remaining in a natural condition in glacial lake and morainal sites. Significant restoration effort is needed even in the best blocks.

Some opportunities exist outside of the mapped boundaries of the Aspen Parkland Natural Region, e.g. summit of Bodo, where there is vegetation similar to that in the Aspen Parkland Natural Region. Even when private lands and areas external to the Aspen Parkland Natural Region are considered, several themes cannot be represented in provincially or higher significance ESAs.

\section{Size and Land Ownership:}

- This is the largest of the three Parkland Subregions, totalling $53413 \mathrm{~km}^{2 *}$

- Over $92 \%$ of the land is privately owned (Table 18 )

- Approximately $5 \%\left(2725 \mathrm{~km}^{2}\right)$ is controlled by the provincial crown and $2 \%\left(1056 \mathrm{~km}^{2}\right)$ is controlled by the federal crown 



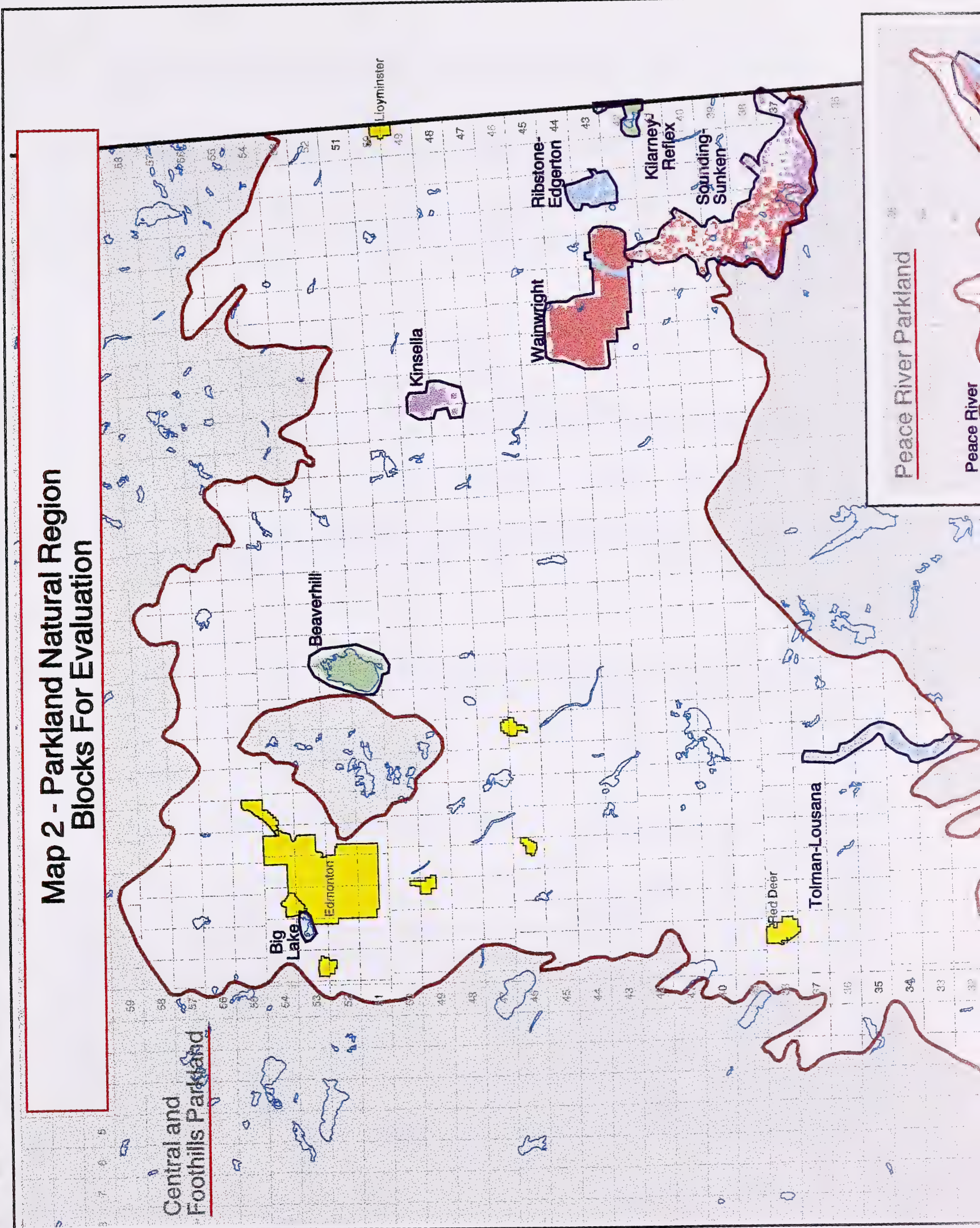




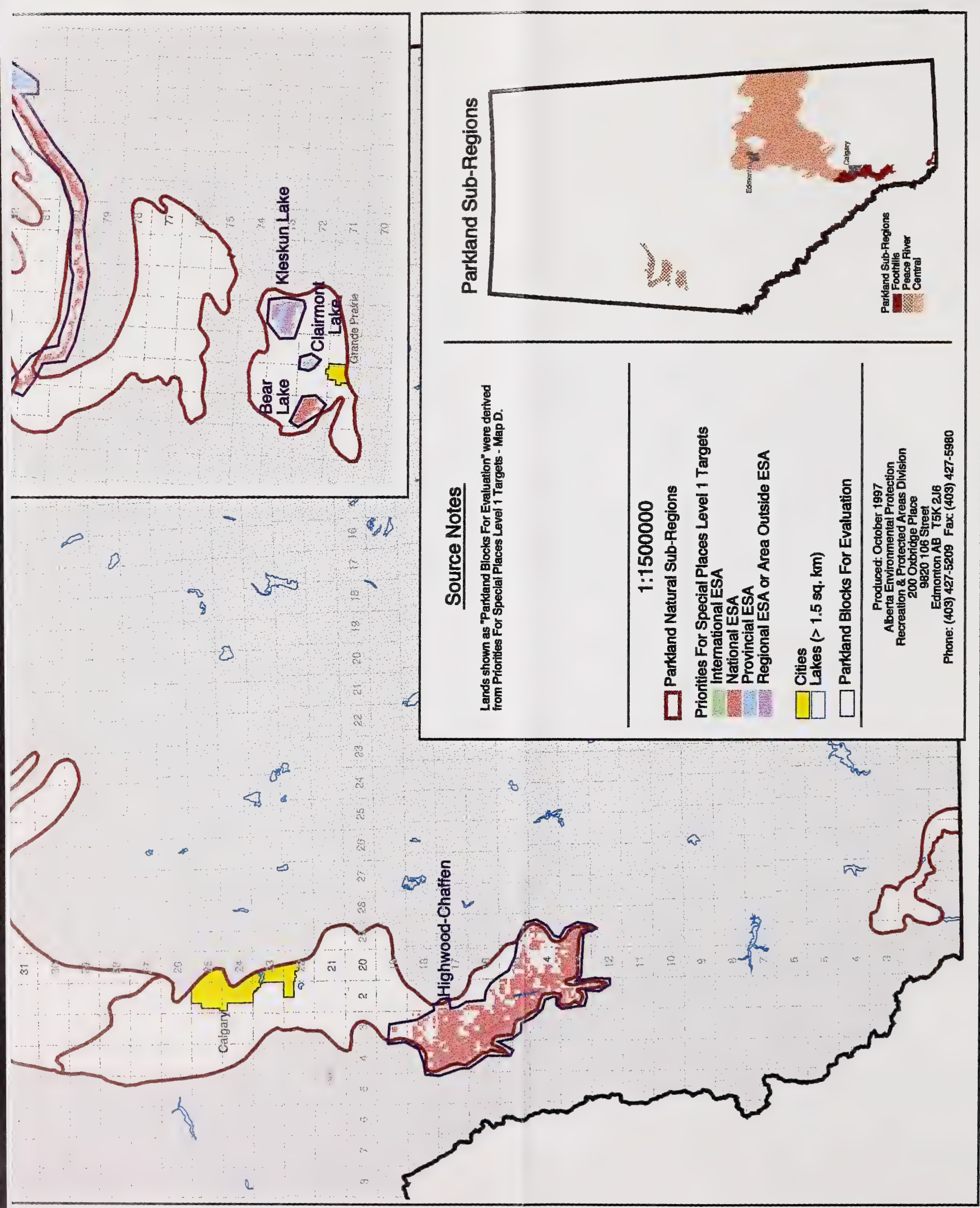


- The largest blocks of crown land occur in the Rumsey and Wainwright and Sounding Lake areas

\begin{tabular}{|l|c|c|c|c|c|c|c|c|c|}
\hline Table 18. Land Ownership Summary - Central Parkland Subregion $\left(\mathbf{k m}^{2}\right)$ \\
\hline & Crown & Freehold & Mixed & Other & Water & $\begin{array}{c}\text { Indian } \\
\text { Reserves }\end{array}$ & $\begin{array}{c}\text { Military } \\
\text { Reserves }\end{array}$ & $\begin{array}{c}\text { Urban } \\
\text { Areas }\end{array}$ & $\begin{array}{c}\text { TOTAL } \\
\mathbf{k m}^{2}\end{array}$ \\
\hline Area $\left(\mathrm{km}^{2}\right)$ & 2725 & 49300 & 878 & 144 & 316 & 409 & 647 & 1192 & $55611^{*}$ \\
\hline$\%$ of Total & 5.1 & 92.3 & 1.6 & .3 & .6 & .8 & 1.2 & 2.2 & 100 \\
\hline * There are discrepancies in totals due to differences in precision levels between digital coverages \\
\hline
\end{tabular}

\section{Integrity:}

- Much of the Subregion is disturbed and fragmented

- Largest city lying in the Subregion is Edmonton

- Contains many towns, villages and the city of Red Deer

- Farming, ranching and energy development are major land uses

- Traversed by many highways (both primary and secondary and a national transportation corridor)

- Has the highest wellsite $\left(1.13 / \mathrm{km}^{2}\right)$ and road densities $\left(1.53 \mathrm{~km} / \mathrm{km}^{2}\right)$ in the Parkland Natural Region

- $\quad 5-10 \%$ remaining in native vegetation; very little remaining in large blocks

- Largest blocks of remaining natural vegetation are at Rumsey and in the Wainwright and Sounding Lake areas

\section{Protected Areas and ESAs:}

- Contains two protected areas larger than $10 \mathrm{~km}^{2}$ (Wainwright Dunes and Rumsey Ecological Reserve) plus the Rumsey South Natural Area, which is contiguous with the Rumsey Ecological Reserve.

- Total of $71\left(3513 \mathrm{~km}^{2}\right)$ Environmentally Significant Areas of Provincial, National or International Significance (Table 19)

\section{Table 19. Central Parkland Subregion ESAs}

\begin{tabular}{|l|l|r|}
\hline \multicolumn{1}{|c|}{ Site Name } & \multicolumn{1}{c|}{ Significance } & \multicolumn{1}{c|}{$\begin{array}{c}\text { Area } \\
\text { (hectares) }\end{array}$} \\
\hline Albert Lake & Provincial & 167 \\
\hline Battle River - Bigknife & National & 16274 \\
\hline Battle River - Brownfield & Provincial & 8566 \\
\hline Battle River - Camp Wainwright & National & 2188 \\
\hline Battle River - Driedmeat Lake & Provincial & 4789 \\
\hline Battle River - Marsden & National & 3821 \\
\hline Battle River - Wainwright & National & 8278 \\
\hline Baxter Lake & National & 1589 \\
\hline Bearhills Lake & Provincial & 1952 \\
\hline Beaverdam Creek & Provincial & 481 \\
\hline
\end{tabular}




\begin{tabular}{|c|c|c|}
\hline Site Name & Significance & $\begin{array}{c}\text { Area } \\
\text { (hectares) }\end{array}$ \\
\hline Beaverhill Lake & International & 19540 \\
\hline Bellshill Lake & National & 1116 \\
\hline Big Hay Lake & National & 1975 \\
\hline Big Lake & Provincial & 2140 \\
\hline Bittern Lake & National & 3821 \\
\hline Bodo & International & 15 \\
\hline Buffalo Lake & International & 17440 \\
\hline Cipher Lake & National & 151 \\
\hline Clarke Lake & Provincial & 418 \\
\hline Cluster of Unnamed Lakes & National & 491 \\
\hline Coal Lake & Provincial & 2147 \\
\hline Delburne Wetlands & \begin{tabular}{|l|} 
Provincial \\
\end{tabular} & 922 \\
\hline Earlie Lake & Provincial & 167 \\
\hline Edberg Slough & Provincial & 594 \\
\hline Edgerton Dunes & \begin{tabular}{|l} 
Provincial \\
\end{tabular} & 10914 \\
\hline Erskine Lake & National & 336 \\
\hline Ewing Lake & National & 1373 \\
\hline Gillespie Lake & Provincial & 1380 \\
\hline Greenlee Lake & \begin{tabular}{|l|} 
National \\
\end{tabular} & 110 \\
\hline Gull Lake & Provincial & 9612 \\
\hline Horseshoe Lake & National & 471 \\
\hline Kenilworth Lake & \begin{tabular}{|l|} 
National \\
\end{tabular} & 1218 \\
\hline Killarney/Dillberry/Leane Lake Complex & International & 3455 \\
\hline Lousana Canyon & Provincial & 7205 \\
\hline Lowden Wetlands & National & 3554 \\
\hline Manawan (Egg) Lake & National & 1760 \\
\hline Marion-Shooting Lake Wetlands & Provincial & 2040 \\
\hline Metiskow Lake & National & 305 \\
\hline Mikwan-Goosequill-Hummock Lakes & National & 3510 \\
\hline Ministik Lake & \begin{tabular}{|l|} 
Provincial \\
\end{tabular} & 244 \\
\hline Mudspring Lake & Provincial & 304 \\
\hline North Saskatchewan River - Edmonton & \begin{tabular}{|l|} 
Provincial \\
\end{tabular} & 7342 \\
\hline North Saskatchewan River - Elk Point & Provincial & 2829 \\
\hline Paintearth & \begin{tabular}{|l} 
Provincial \\
\end{tabular} & 4592 \\
\hline Peter's Pond & Provincial & 341 \\
\hline Pine Lake & Provincial & 1300 \\
\hline Plain Lake & Provincial & 842 \\
\hline Pointe-Aux-Pins Soapholes & Provincial & 89 \\
\hline Red Deer Lake & \begin{tabular}{|l|} 
Provincial \\
\end{tabular} & 2956 \\
\hline Reflex Lake & International & 569 \\
\hline
\end{tabular}




\begin{tabular}{|c|c|c|}
\hline Site Name & Significance & $\begin{array}{c}\text { Area } \\
\text { (hectares) }\end{array}$ \\
\hline Ribstone Creek - Camp Wainwright & Provincial & 5397 \\
\hline Ribstone Creek - Edgerton & Provincial & 1775 \\
\hline Ribstone Lake & Provincial & 726 \\
\hline Rumsey North & Provincial & 11392 \\
\hline Rumsey South & International & 4653 \\
\hline Samson Lake & Provincial & 2355 \\
\hline Silver Heights & National & 11374 \\
\hline Sounding Dunes & National & 56929 \\
\hline Sounding Lake & National & 5310 \\
\hline Sunken Lake & Provincial & 417 \\
\hline Tolman Badlands & Provincial & 15504 \\
\hline Unnamed Lake S of Sunken L & National & 187 \\
\hline Vermilion Lake - Vermilion Provincial Park & Provincial & 822 \\
\hline$\overline{\mathrm{W}}$ agner Natural Area & Provincial & 752 \\
\hline Wainwright Base & National & 53394 \\
\hline Wainwright Dunes Ecological Reserve & Provincial & 3178 \\
\hline Watt Lake & Provincial & 2660 \\
\hline Wavy Lake & National & 1910 \\
\hline Whitford-Rush Lakes & National & 1745 \\
\hline Willow Lake & Provincial & 2830 \\
\hline Wood Lake & Provincial & 280 \\
\hline CENTRAL PARKLAND TOTAL $\left(\mathrm{km}^{2}\right)$ & & 3513 \\
\hline Provincial & National & International \\
\hline 1224 & 1832 & 457 \\
\hline
\end{tabular}

\section{Targets and Prospects for Protection:}

The target for protection of Level 1 Natural History Themes is $1417.5 \mathrm{~km}^{2}$ or about $2.7 \%$ of the Subregion. To date two protected areas larger than $10 \mathrm{~km}^{2}$ have been established within the Subregion and about . $1 \%$ of the overall target of $1417.5 \mathrm{~km}^{2}$ has been achieved. There are a limited number of suitable areas within the Subregion from which the remaining Level 1 NHT targets can be drawn. Areas with the greatest potential include Beaverhill Lake, SoundingSunken, Ribstone-Edgerton, Wainwright, Killarney-Reflex, Tolman-Lousana, Big Lake and Kinsella (Map 2). Table 20 summarizes the Level 1 NHTs (and the appropriate area of each) on the crown lands within the above areas. 


Table 20. THEME REPRESENTATION (PUBLIC LAND)
- CENTRAL PARKLAND (sq. km)
\begin{tabular}{|l|c|c|c|c|c|c|c|c|c|c|c|c|c|c|c|}
\hline \multicolumn{1}{|c|}{ Site Name } & NL & NG & NH & SS & SD & SK & VX & VP & VF & VS & WM & WD & WL & WS & WA \\
\hline Sounding-Sunken & 4 & 1.7 & 1 & 219.6 & 32.5 & 0 & 0 & 0 & .9 & 4.2 & 25.7 & .3 & 3.4 & 2.7 & 45.8 \\
\hline Ribstone-Edgerton & & 0 & 0 & 17.9 & 50.2 & 0 & 0 & 0 & 6.1 & 0 & .4 & 0 & 0 & .2 & 0 \\
\hline Killarney-Reflex & 0 & 0 & 0 & 0 & 3.6 & 1.0 & 0 & 0 & 0 & .6 & 1.2 & 0 & 15.4 & 0 & 9.2 \\
\hline Kinsella & 0 & 0 & 24 & 0 & 0 & 0 & 0 & 0 & 0 & 0 & 15 & .5 & 0 & 1.5 & 0 \\
\hline Beaverhill Lake & 15.2 & 0 & 0 & 0 & 0 & 0 & 0 & 0 & 0 & 0 & 0 & 0 & 144 & 0 & 0 \\
\hline Tolman-Lousana & 0 & 0 & 0 & 0 & 0 & 0 & 31.2 & 23.9 & 21.6 & 1.6 & 0 & 0 & 0 & 0 & 0 \\
\hline Big Lake & 0 & 0 & 0 & 0 & 0 & 0 & 0 & 0 & 0 & 0 & 3.9 & 7.9 & 3.0 & 3.9 & 0 \\
\hline Wainwright & & 1.9 & 29 & 124 & 161.2 & 170.5 & 2.0 & 4.1 & 26.5 & 1.1 & 30.2 & 11.3 & 0 & 18.2 & 0 \\
\hline TOTAL & $\mathbf{1 9 . 2}$ & $\mathbf{3 . 6}$ & $\mathbf{5 4}$ & $\mathbf{3 1 6 . 5}$ & $\mathbf{2 4 7 . 5}$ & $\mathbf{1 7 1 . 5}$ & $\mathbf{3 3 . 2}$ & $\mathbf{2 8}$ & $\mathbf{5 5 . 1}$ & $\mathbf{7 . 5}$ & $\mathbf{7 6 . 4}$ & $\mathbf{2 0}$ & $\mathbf{1 6 5 . 8}$ & $\mathbf{2 6 . 5}$ & $\mathbf{5 5}$ \\
\hline TARGET & $\mathbf{2 5 0}$ & $\mathbf{2 5 0}$ & $\mathbf{2 5 0}$ & $\mathbf{2 5 0}$ & $\mathbf{1 0 0}$ & $\mathbf{1 0 0}$ & $\mathbf{2 5}$ & $\mathbf{2 5}$ & $\mathbf{2 5}$ & $\mathbf{2 . 5}$ & $\mathbf{1 0}$ & $\mathbf{1 0}$ & $\mathbf{1 0}$ & $\mathbf{1 0}$ & $\mathbf{1 0}$ \\
\hline
\end{tabular}

$\begin{array}{lll}\text { NL - Glacial Lake Bed } & \text { VX - Exposed Slope } & \text { WM - Wet Meadow } \\ \text { NG - Ground Moraine } & \text { VP - Protected Slope } & \text { WD - Deep Marsh } \\ \text { NH- Hummocky Moraine } & \text { VF - Valley Floor } & \text { WS - Shallow Marsh } \\ \text { SS - Sand Plain } & \text { VS - Springs } & \text { WA - Alkali Wetland } \\ \text { SD - Sand Dune } & & \text { WL - Lake } \\ \text { SK - Kame Moraine } & & \end{array}$

\section{Beaverhill Lake}

\section{ESA: PARKLAND; POSTON}

Area (ha): 19547 plus some adjacent crown land

Location:

- Beaverhill Lake and adjacent uplands

- NTS Map Sheet: $83 \mathrm{H}$

Municipality: County of Beaver

Significance: International

- RAMSAR site

- Beaverhill Lake is one of the most important bird habitats in western North America

- internationally significant waterbody for shorebirds and waterfowl, in particular, as a staging area for migratory birds flying to and from the Arctic

Description:

- 272 species have been reported in the area with 145 species known to breed locally

- exposed mudflats, vegetated shorelines and islands are some of the numerous habitats that comprise Beaverhill Lake

- Piping Plover breeding lake, a COSEWIC endangered species in Canada and a red-listed 
species in Alberta and numerous other rare avian species

- includes Beaverhill Natural Area

- national importance for breeding and moulting waterfowl

Potential to Contribute to Level 1 Natural History Theme Representation:

Crown lands have excellent potential for contributing to the following Level 1 NHTs that are currently underrepresented in protected areas: Glacial Lake Bed, Lake

Recommendations:

- All crown lands should be maintained in their natural state

\section{Big Lake}

\section{ESA: STURGEON}

Area (ha): 2140

Location:

- Big Lake

- NTS Map Sheet 83H

Municipality: MD of Sturgeon

Significance: Provincial

- recognized as one of the twenty most important waterfowl habitat units in the province

- proximity to a large urban centre adds to its importance since the area is easily accessed and has very significant tourist, interpretative and educational potential

Description:

- very important and diverse lake and riparian habitats; the lake is a Wetlands For Tomorrow site

- no significant limitations to the production of waterfowl

- very important moulting, staging and migration lake for waterfowl

- a large colony of Franklin's Gulls on the west bay of the lake

- colonies of Eared Grebe and Black Tern (a yellow A-listed species in Alberta)

- interesting birdsfoot delta of Sturgeon River

- the south shore supports large stands of mature aspen, birch and white spruce which have important value and provide habitat for non-game wildlife species

- acts as a natural reservoir and flood control entity for the city of St. Albert

- other species include Sandhill Crane, upland game birds including a self-sustaining pheasant population, furbearers such as Mink, weasel and Muskrat, and Mule Deer

Potential to Contribute to Level 1 Natural History Theme Representation:

Crown lands have excellent potential for contributing to the following Level 1 NHTs that are currently underrepresented in protected areas: Wet Meadow, Shallow Marsh, Deep Marsh, Lake 
Recommendations:

- All crown lands should be maintained in their natural state

3. Ribstone-Edgerton

- (includes Edgerton Dunes and Ribstone Creek-Edgerton ESA)

\section{ESA: PARKLAND}

Area (ha): 12706

Location:

- situated east of Wainwright along Ribstone Creek

- NTS Map Sheet: '73D

Municipality: MD of Wainwright

Significance: Provincial

- one of the most diverse complexes of sand plains, active dunes, calcareous fens and productive riparian habitats in the Parkland of Alberta

Description:

- remnant Aspen Parkland on sand plain uplands

- aspen groves are interspersed with grassland, eolian landforms and associated vegetation

- inter-dune fen complex

- variety of wetland types

- Ribstone Creek flows through this area

- dunes and eolian/wetland complexes

- unique dune ridges with associated vegetation

- high diversity of breeding birds

- key Mule and White-tailed Deer habitat

- Sharp-tailed Grouse dancing grounds in upland (a yellow listed species in Alberta)

- habitat for Ferruginous Hawk, a vulnerable species

- additional clearing is ongoing in the vicinity of this area

- includes Edgerton Natural Area

Potential to Contribute to Level 1 Natural History Theme Representation:

Crown lands have excellent potential for contributing to the following Level 1 NHTs that are currently underrepresented in protected areas: Sandy Plain, Sand Dune,

Floor/Stream.

Recommendations:

- All crown lands should be maintained in their natural state 


\section{Killarney-Reflex}

- (includes Killarney/Dillberry/Leane Lake Complex and Reflex Lake ESAs)

\section{ESA: PARKLAND}

Area (ha): 4013

Location:

- site includes Killarney Lake, Dillberry Lake, Long Lake, Reflex Lake and Leane Lake

- includes Dillberry Lake Provincial Park

- NTS Map Sheet: 73D

Municipality: MD of Wainwright

Significance: International

- major nesting area for Piping Plover, a COSEWIC endangered species in Canada and a redlisted species in Alberta

- Reflex Lake has one of the densest breeding populations of Piping Plovers (a COSEWIC endangered species in Canada and red-listed species in Alberta) in the world

- internationally significant shorebird migration area

- some of the largest reported concentrations of Stilt Sandpipers in the world

Description:

- high diversity of breeding and migratory birds

- diverse kame moraine, sandy plain and sand dune habitat

- nationally significant shorebird migration area

- small alkali lake complex located on the Alberta-Saskatchewan border

- aquatic vegetation grows abundantly in the shallow bays of these lakes and in a narrow fringe along parts of the shoreline

- Leane and Long Lake provide habitat for nesting waterfowl and marsh birds

- Piping Plovers also nest at Killarney Lake

- Dillberry Lake is regularly stocked with Rainbow Trout, which, along with Yellow Perch, supports a popular sport fishery

- 21 species of mammals have been reported to occur within lake complex including White-tailed Jackrabbit and Long-tailed Weasel, a yellow A-listed species in Alberta, and Mule and Whitetailed Deer

- six species of amphibians and reptiles including Chorus and Northern Leopard Frog (a redlisted species in Alberta)

- rare plants

Potential to Contribute to Level 1 Natural History Theme Representation:

Crown lands have excellent potential for contributing to the following Level 1 NHTs that are currently underrepresented in protected areas: Sand Dune, Lake, Alkali Wetland 
Recommendations:

- All crown lands should be maintained in their natural state

\section{Kinsella}

ESA: not previously identified

Area (ha): 4100

Location:

- hummocky moraine north of Kinsella

- NTS Map Sheet: 73D

Municipality: MD of Flagstaff

Significance: Provincial

- one of very few blocks of Central Parkland in Alberta

Description:

- diversity of vegetation communities, including rough fescue interspersed with aspen groves

- waterfowl staging and production lakes

- key deer habitat in upland

- fragmented by non-native pasture areas

Potential to Contribute to Level 1 Natural History Theme Representation:

Crown lands have moderate potential for contributing to the following Level 1 NHTs:

Hummocky Moraine; Wet Meadow; Shallow Marsh.

Recommendations:

- All crown lands should be maintained in their natural state

6. Sounding-Sunken

- includes Cluster of Unnamed Lakes (Hughenden), Sounding Dunes, Sounding Lake, Greenlee Lake, Metiskow Lake, Sunken Lake, Horseshoe Lake and Unnamed Lake (South of Sunken Lake) ESAs

ESA: PARKLAND

Area (ha): 64481

Location:

- sand plain and dunes in Sounding Lake-Sunken Lake-Metiskow area

- NTS Map Sheet: 73D

Municipality: MD of Provost; Special Area 4 
Significance: National

- some of the most productive shorebird staging areas in Canada

- breeding sites for Piping Plover (a COSEWIC endangered species in Canada and a red-listed species in Alberta)

Description:

- small alkali lakes

- diversity of vegetation communities, including rough fescue-porcupine grass interspersed with aspen groves

- dune and eolian/wetland complexes

- high species diversity

- significant shorebird staging lakes

- waterfowl staging and production lakes

- evidence of Piping Plover (a COSEWIC endangered species in Canada and a red-listed species in Alberta) feeding or staging on some lakes

- key Mule and White-tailed Deer habitat in upland

- Sharp-tailed Grouse dancing grounds (a yellow A-listed species in Alberta)

- only known location for round-leaf monkeyflower (Mimulus glabratus) in Alberta

- heavily fragmented and checkerboarded with private land

- possibilities of connectivity from fescue grassland sites at Grassy Island Lake and Bodo-Altario through Wainwright and Battle River

Potential to Contribute to Level 1 Natural History Theme Representation:

Crown lands have excellent potential for contributing to the following Level 1 NHTs that are currently underrepresented in protected areas: Glacial Lake Bed, Sandy Plain, Sand Dune, Springs, Wet Meadow, Lake, Alkali Wetland and Shallow Marsh.

Recommendations:

- All crown lands should be maintained in their natural state

7. Tolman-Lousana

- includes Tolman Badlands and Lousana Canyon ESAs

ESA: KNEEHILL; STETTLER; STARLAND; RED DEER

Area (ha): 37084

Location:

- valley of Red Deer River and tributary coulees from Tail Creek south to Horsethief Canyon

- includes Big Valley coulee

- NTS Map Sheet: 82P, 83A

Municipality: MD of Starland; County of Stettler; County of Red Deer; MD of Kneehill 
Significance: Provincial

- part of the deepest and most spectacular canyon in the Aspen Parkland/Fescue Grassland of Alberta

- some of the best-developed mass-wasting valley features and associated diverse habitats in the Parkland Region of Alberta

- some of the most diverse valley and productive bird of prey habitats in Alberta

Description:

- narrow, deep valley of the Red Deer River

- diverse valley habitats from springs, badlands, grasslands, sagebrush flats and shrubbery to aspen woodland, dense white spruce forests and riparian poplar woods

- mature balsam poplar woodlands

- includes small remnants of adjacent upland parkland and grassland

- significant bedrock exposures and badlands

- extensive slump blocks and perched wetland development with regionally uncommon plant species, including reed (Phragmites australis)

- diversity of breeding birds

- historical Peregrine Falcon nesting area

- rare or uncommon birds: Black-and-White Warbler, Brewer's Sparrow, Pileated Woodpecker and Loggerhead Shrike, the latter a COSEWIC endangered species in Canada

- priority habitat for duck staging, goose production and non-game migratory birds

- prime nesting habitat for rare birds of prey including: Prairie Falcon (rare in the region), Turkey Vulture (local in Alberta), Merlin and Ferruginous Hawk (COSEWIC vulnerable species)

- key Mule Deer and White-tailed Deer habitat

- Northern Leopard Frog, a species which has been in decline through central Alberta

- important fish habitat including a spawning, rearing and overwintering area upstream of Tolman Bridge for Northern Pike, Walleye, Goldeye, Eastern Brook Trout, Brown Trout, Mooneye, Rainbow Trout, Sauger and Sucker

- regionally uncommon plants: white birch (Betula papyrifera), Indian breadroot (Psoralea esculenta) and blue columbine (Aquilegia brevistyla)

- includes five Natural Areas (Big Valley, Lousana, Nevis, Delburne and Wood Lake)

- small patches of clearing and cultivation

Potential to Contribute to Level 1 Natural History Theme Representation:

Crown lands have excellent potential for contributing to the following Level 1 NHTs that are currently underrepresented in protected areas: Exposed Slope, Protected Slope, Valley Floor, and Springs.

Recommendations:

- All crown lands should be maintained in their natural state

\section{Wainwright}

- includes Wainwright Dunes Ecological Reserve, Wainwright Base, Ribstone Creek-Camp Wainwright and Battle River-Camp Wainwright ESAs 


\section{ESA: PARKLAND}

Area (ha): 64089

Location:

- Wainwright Military Base and surrounding area

- NTS Map Sheet: 73D

Municipality: County of Flagstaff; MD of Wainwright

Significance: National

- includes an interprovincial waterway

- one of the most extensive and diverse sand plain, river valley, calcareous fen and wetland complexes in the Aspen Parkland of Canada

Description:

- high landform diversity including hummocky moraine, kames and eolian/wetland complexes (inter-dune fen complex, patterned fens)

- large area with creeks, springs and small lakes

- good representative of the Central Parkland Natural Subregion

- aspen groves are interspersed with grassland, eolian landforms and associated vegetation

- extensive sand plain and sand dunes

- active blowouts with rare plants

- diverse, undisturbed riparian communities

- variety of streamside vegetation from saline seepage to extensive willow poplar stands

- extensive riparian poplar, willow and wetland habitats

- extensive springs

- variety of productive sand plain wetlands

- key Mule and White-tailed Deer habitat

- rare plant species including Gentiana aquatica and Ruppia occidentalis

- diverse breeding bird communities

- key deer habitat

- numerous Sharp-tailed Grouse dancing grounds (a yellow A-listed species in Alberta)

- waterfowl nesting and staging area, particularly dabbling ducks

- includes patches of range improvement; additional clearing is ongoing in the area

- agricultural clearing has impacted portions of the valley habitat

- relatively undisturbed, especially to the south and east

- important overwintering, spawning and rearing for Northern Pike, Goldeye and Walleye

Potential to Contribute to Level 1 Natural History Theme Representation:

Crown lands have excellent potential for contributing to the following NHTs that are currently underrepresented in protected areas: Hummocky Moraine, Sandy Plain, Sand Dune, Springs, Valley Floor, Wet Meadow, Deep Marsh and Shallow Marsh. It is the only area with significant Kame Moraine representation on Crown land. 
Recommendations:

- All crown lands should be maintained in their natural state

\subsubsection{Foothills Parkland Subregion}

\section{Size and Land Ownership:}

- This is the smallest of the three Parkland Subregions, totalling $4402 \mathrm{~km}^{2 *}$

- Over $75 \%$ of the land is privately owned (Table 21 )

- Approximately $22 \%\left(949 \mathrm{~km}^{2}\right)$ is controlled by the provincial crown and $4 \%\left(187 \mathrm{~km}^{2}\right)$ is controlled by the federal crown

- The largest block of crown land occurs in the Highwood-Chaffen area north of the Whaleback

Table 21. Land Ownership Summary - Foothills Parkland Subregion $\left(\mathbf{k m}^{2}\right)$

\begin{tabular}{|l|l|l|l|l|l|l|l|l|l|}
\hline & Crown & Freehold & Mixed & Other & Water & $\begin{array}{l}\text { Indian } \\
\text { Reserves }\end{array}$ & $\begin{array}{l}\text { Military } \\
\text { Reserves }\end{array}$ & $\begin{array}{l}\text { Urban } \\
\text { Areas }\end{array}$ & $\begin{array}{l}\text { TOTAL } \\
\mathbf{k m}^{2}\end{array}$ \\
\hline Area $\left(\mathrm{km}^{2}\right)$ & 949 & 3326 & 127 & 1 & 0 & 181 & 6 & 302 & 4892 \\
\hline$\%$ of Total & 21.6 & 75.6 & 2.9 & 0 & 0 & 4.1 & .1 & 6.9 & 100 \\
\hline
\end{tabular}

*There are discrepancies in totals due to differences in precision levels between digital coverages

The target for protection of Level 1 Natural History Themes is $227.5 \mathrm{~km}^{2}$ or about $5.2 \%$ of the Subregion. To date there have been no protected areas that satisfy the $10 \mathrm{~km}^{2}$ size criteria established within the Subregion. There are a limited number of suitable crown land areas within the Subregion from which the Level 1 NHT targets can be satisfied. The area with the greatest potential is Highwood-Chaffen.

\section{Integrity:}

- Much of the Subregion is disturbed and fragmented

- Largest city partially lying in the Subregion is Calgary

- Farming and ranching are major land uses

- Country residential development is increasing rapidly

- Traversed by several highways (both primary and secondary)

- Has the lowest wellsite $\left(.27 / \mathrm{km}^{2}\right)$ and road densities $\left(.79 \mathrm{~km} / \mathrm{km}^{2}\right)$ in the Parkland Natural Region

- Highwood-Chaffen is the only remaining large block of Crown land

- smaller blocks of Crown or private lands occur in the Police Outpost, Paine-Beaverdam, Waterton fringe, Cross Conservancy/Pothole Creek, Tsuu Tina Reserve and Bighill Creek areas 


\section{Protected Areas and ESAs:}

- Contains no protected areas that meet the $10 \mathrm{~km}^{2}$ size criteria

- Total of $15\left(863 \mathrm{~km}^{2}\right)$ Environmentally Significant Areas of Provincial, National or International Significance (Table 22)

Table 22. Foothills Parkland Subregions ESAs

\begin{tabular}{|c|c|c|}
\hline Site Name & Significance & Area (hectares) \\
\hline Beaverdam Creek & Provincial & 699 \\
\hline Big Hill Creek & Provincial & 2250 \\
\hline Cloudy Ridge & Provincial & 428 \\
\hline Cross Conservancy/Pothole Creek & Provincial & 1300 \\
\hline Dungarvan Wetlands & Provincial & 383 \\
\hline $\begin{array}{l}\text { Highwood Chaffen (including Highwood-Pekisko } \\
\text { Upland, Meinsinger Lake and Pekisko Creek and } \\
\text { Highwood-Pekisko Additions) }\end{array}$ & National & 71048 \\
\hline Horseshoe Lake & Provincial & 75 \\
\hline Lee Creek Ponds & Provincial & 98 \\
\hline Margaret Lake & Provincial & 893 \\
\hline Okotoks Erratic & International & 9 \\
\hline Paine - Beaverdam & National & 2613 \\
\hline Pine Ridge & Provincial & 4950 \\
\hline Police Outpost & National & 527 \\
\hline Sarcee (Tsuu Tsina Reserve) & Provincial & 6646 \\
\hline Sheep River & Provincial & 1416 \\
\hline FOOTHILLS PARKLAND TOTAL $\left(\mathbf{k m}^{2}\right)$ & & 863 \\
\hline Provincial & National & International \\
\hline 191 & 671 & .1 \\
\hline
\end{tabular}

\section{Targets and Prospects for Protection:}

The target for protection of Level 1 Natural History Themes is $227.5 \mathrm{~km}^{2}$ or about $5.2 \%$ of the Subregion. To date there have been no protected areas that satisfy the $10 \mathrm{~km}^{2}$ size criteria 
established within the Subregion. There are a limited number of suitable crown land areas within the Subregion from which the Level 1 NHT targets can be satisfied. The area with the greatest potential is Highwood-Chaffen (Map 2). Table 23 summarizes the Level 1 NHTs and the approximate area each covers within the Highwood Chaffen block.

Table 23. THEME REPRESENTATION (PUBLIC LAND) - FOOTHILLS PARKLAND (SQ. KM)

\begin{tabular}{|l|c|c|c|c|c|c|c|c|c|c|}
\hline Site Name & NL & NG+ & VX & VP & VF & VV* & VS & WM & WD & WS \\
\hline Highwood-Chaffen* & 11.6 & 94.8 & 16.7 & 47.5 & 86.2 & 365.6 & 7.7 & 3.5 & 3.4 & 3.1 \\
\hline TARGET & $\mathbf{2 5}$ & $\mathbf{1 0 0}$ & $\mathbf{1 0}$ & $\mathbf{1 0}$ & $\mathbf{3 5}$ & $\mathbf{2 5}$ & $\mathbf{2 . 5}$ & $\mathbf{1 0}$ & $\mathbf{1 0}$ & $\mathbf{1 0}$ \\
\hline
\end{tabular}

* - of this figure, about $50-75 \mathrm{sq}$. $\mathrm{km}$ along the western extremity is probably atypical and more representative of Montane

+ - of this figure, about 25 sq. $\mathrm{km}$ near the Porcupine Hills is atypical and more representative of Montane

NL - Glacial Lake Bed

VV - Ridge/Valley Wall

NG - Ground Moraine

VS - Springs

VX - Exposed Slope

WM - Wet Meadow

VP - Protected Slope

WD - Deep Marsh

VF - Valley Floor

WS - Shallow Marsh

\section{Highwood-Chaffen}

- includes Pekisko Creek, Highwood-Pekisko Upland and Meinsinger Lake ESAs

\section{ESA: CALGARY; POSTON}

Area (sq. km.): 640

Location:

- includes the northernmost slopes of the Porcupine Hills and Chain Lakes Provincial Park

- parallels the Livingstone and Highwood Ranges from the Northern Porcupine Hills to the Longview area

- $\quad$ NTS Mapsheet: 82I, 82J

Municipality: MD of Ranchland; MD of Foothills

Significance: National

- one of the seven most significant remaining blocks of Foothills Parkland in Alberta

- some of the most extensive foothills parkland willow in Alberta

- one of the finest Moose ranges in Alberta 
- the most extensive area of Foothills Parkland in Canada

Description:

- diverse foothills ridges and valleys on a variety of geological substrates

- variety of grassland, wetland and woodland habitats

- excellent Elk habitat

- numerous small wetlands

- important spawning habitat for Bow River Rainbow Trout in Pekisko Creek

- Poston lists Meinsinger Lake as provincially significant Great Blue Heron breeding habitat

- area has figured prominently in the history of ranching in southern Alberta

- historical interest because the Prince-of-Wales (Edward VIII) once owned a ranch there

Potential to Contribute to Level 1 Natural History Theme Representation:

Crown lands have excellent potential for contributing to the following NHTs that are currently underrepresented in protected areas: Glacial Lake Bed, Ground Moraine, Exposed Slope, Protected Slope, Valley Floor, Ridge/Valley Wall, Springs, Wet Meadow, Deep Marsh and Shallow Marsh.

Recommendations:

- $\quad$ All crown lands should be maintained in their natural state

\subsubsection{Peace River Parkland Subregion}

There is virtually no upland parkland left either in public or private ownership. The most extensive parkland vegetation occurs along the Peace River valley, much of it crown land. Some opportunities exist outside of the mapped boundaries of the Aspen Parkland Natural Region, e.g. Peace River valley, where there is vegetation similar to that in the Aspen Parkland Natural Region. Even when private lands and areas external to the Aspen Parkland Natural Region are considered, several themes cannot be represented in provincially or higher significance ESAs.

Although the following are classed as Peace River Parkland they are more typical of Dry Mixedwood vegetation:

Birch Hills

Saddle Hills (north and east edge)

\section{Size and Land Ownership:}

- This is a relatively small Subregion, totalling $4665 \mathrm{~km}^{2 *}$

- $85 \%$ of the land is privately owned (Table 24 )

- Approximately $11 \%\left(511 \mathrm{~km}^{2}\right)$ is controlled by the provincial crown

- The largest block of crown land occurs along the south-facing slopes of the Peace River west of the town of Peace River 
Table 24. Land Ownership Summary - Peace River Parkland Subregion $\left(\mathbf{k m}^{2}\right)$

\begin{tabular}{|l|c|c|c|c|c|c|c|c|c|}
\hline & Crown & Freehold & Mixed & Other & Water & $\begin{array}{c}\text { Indian } \\
\text { Reserves }\end{array}$ & $\begin{array}{c}\text { Military } \\
\text { Reserves }\end{array}$ & $\begin{array}{c}\text { Urban } \\
\text { Areas }\end{array}$ & $\begin{array}{c}\text { TOTAL } \\
\mathbf{k m}^{2}\end{array}$ \\
\hline Peace River & 511 & 3960 & 90 & 82 & 21 & 6 & 0 & 79 & 4749 \\
\hline$\%$ of Total & 11.0 & 84.9 & 1.9 & 1.8 & .5 & .1 & 0 & 1.7 & 100 \\
\hline
\end{tabular}

\section{Integrity:}

- Much of the Subregion is disturbed and fragmented

- Largest city lying in the Subregion is Grande Prairie

- Farming and ranching are major land uses

- Traversed by several highways (both primary and secondary)

- Has a relatively low wellsite $\left(.41 / \mathrm{km}^{2}\right)$ and a moderately high road density $\left(1.12 \mathrm{~km} / \mathrm{km}^{2}\right)$ compared with other Subregions in the Parkland Natural Region

- Peace River and Kleskun Lake are the only remaining large blocks of Crown upland

- other Crown properties are represented in wetlands and lakes

\section{Protected Areas and ESAs:}

- Contains no protected areas that meet the $10 \mathrm{~km}^{2}$ size criteria

- Total of $14\left(225 \mathrm{~km}^{2}\right)$ Environmentally Significant Areas of Provincial, National or International Significance (Table 25) 


\begin{tabular}{|l|l|r|}
\hline \multicolumn{2}{|c|}{ Table 25. Peace River Parkland Subregion ESAs } \\
\hline Bear Lake & \multicolumn{1}{|c|}{ Significance } & Area (hectares) \\
\hline Buffalo Lake Complex & National & 4200 \\
\hline Flyingshot Lake & National & 975 \\
\hline Kleskun Hill & National & 269 \\
\hline $\begin{array}{l}\text { Peace River including Representative Area (\#89) } \\
\text { as well as Peace River - Dunvegan, Peace River - } \\
\text { Parkland and Smoky River }\end{array}$ & National & 2420 \\
\hline Clairmount Lake & & 10687 \\
\hline Feguson Lake & Provincial & 1202 \\
\hline Kakut Lake & Provincial & 443 \\
\hline Kleskun Lake & Provincial & 544 \\
\hline Wood Lake & Provincial & 1601 \\
\hline PEACE RIVER PARKLAND TOTAL (km $\left.{ }^{2}\right)$ & & 150 \\
\hline & Provincial & National \\
\hline
\end{tabular}

\section{Targets and Prospects for Protection:}

The target for protection of Level 1 Natural History Themes is $150 \mathrm{~km}^{2}$ or about $3 \%$ of the Subregion. To date there have been no protected areas that satisfy the $10 \mathrm{~km}^{2}$ size criteria established within the Subregion. There are a limited number of suitable crown land areas within the Subregion from which the Level 1 NHT targets can be satisfied. The areas with the greatest potential are Peace River and Kleskun, Clairmont and Bear Lakes (Map 2). Table 26 summarizes the Level 1 NHTs and the approximate area each covers in the above sites. 
Table 26. THEME REPRESENTATION (PUBLIC LAND) - PEACE RIVER PARKLAND (sq.km)

\begin{tabular}{|c|l|c|c|c|c|c|c|c|}
\hline Site Name & NL & VX & VP & VF & WM & WD & WS & WL \\
\hline Kleskun Lake+ & & & & & 3.2 & 5.6 & 2.4 & 2.4 \\
\hline Peace River Sites* & & 25.2 & 15.8 & 3.0 & & & & \\
\hline Clairmont Lake & & & & & .2 & .6 & .2 & 10.7 \\
\hline Bear Lake & & & & & .8 & 2.1 & .8 & 38.2 \\
\hline TOTAL & & $\mathbf{2 5 . 2}$ & $\mathbf{1 5 . 8}$ & $\mathbf{3 . 0}$ & $\mathbf{4 . 2}$ & $\mathbf{7 . 7 6}$ & $\mathbf{3 . 4}$ & $\mathbf{5 0 . 5}$ \\
\hline TARGET & $\mathbf{5 0}$ & $\mathbf{2 5}$ & $\mathbf{2 5}$ & $\mathbf{1 0}$ & $\mathbf{1 0}$ & $\mathbf{1 0}$ & $\mathbf{1 0}$ & $\mathbf{1 0}$ \\
\hline
\end{tabular}

+ more than double this area is previously disturbed lands available for restoration of these themes

* includes valley sites at Peace River-Dunvegan, Peace River-Parkland, Peace River-Smoky Junction and Smoky River sites--significantly more of these themes occur on Public Land outside the formal Peace River Parkland boundary and would allow targets to be met for these themes

NL - Glacial Lake Bed

$$
\begin{aligned}
& \text { WM - Wet Meadow } \\
& \text { WD - Deep Marsh } \\
& \text { WS - Shallow Marsh } \\
& \text { WL - Lake }
\end{aligned}
$$$$
\text { VP - Protected Slope }
$$

\section{Bear Lake}

ESA: PARKLAND; POSTON

Area (ha): 4200

Location:

- Bear Lake

- NTS Map Sheet: 83M

Municipality: County of Grande Prairie

Significance: National

- Poston lists as nationally significant duck staging habitat 
Description:

- Trumpeter Swan nesting lake, a blue-listed species in Alberta

- significant waterfowl habitat

Potential to Contribute to Level 1 Natural History Theme Representation:

Crown wetland with excellent potential for contributing to the following Level 1 NHTs that are currently underrepresented in protected areas: Lake, Wet Meadow, Shallow Marsh and Deep Marsh.

Recommendations:

- All crown lands should be maintained in their natural state

\section{Clairmount Lake}

\section{ESA: PARKLAND; POSTON}

Area (ha): 1202

Location:

- Clairmount Lake

- NTS Map Sheet: $83 \mathrm{M}$

Municipality: County of Grande Prairie

Significance: Provincial

- one of relatively few productive Trumpeter Swan (blue-listed species in Alberta) breeding lakes in Alberta

- Poston lists as provincially significant duck staging habitat

Description:

- Ducks Unlimited wetland

- significant waterfowl production and staging wetland

Potential to Contribute to Level 1 Natural History Theme Representation:

Crown wetland with excellent potential for contributing to the following Level 1 NHTs that are currently underrepresented in protected areas: Lake and Deep Marsh.

Recommendations:

- All crown lands should be maintained in their natural state

\section{Kleskun Lake}

\section{ESA: POSTON}

Name: Kleskun Lake (additional Crown land available in non-native vegetation) 
Area (ha): 1601

Location:

- Kleskun Lake wetlands

- NTS Map Sheet: 83M

Municipality: County of Grande Prairie

Significance: Provincial

- Poston lists as provincially significant staging duck and breeding and non-breeding Franklin's Gull habitat

Description:

- extensive sedge and willow wetlands

- modified for grazing

Potential to Contribute to Level 1 Natural History Theme Representation:

Crown lands have excellent potential for contributing to the following Level 1 NHTs that are currently underrepresented in protected areas: Lake, Wet Meadow, Deep Marsh and Shallow Marsh.

Recommendations:

- All crown lands should be maintained in their natural state

- Previously disturbed crown lands should be allowed to return to a natural state

4. Peace River

- includes Peace River - Parkland as well as portions of Representative Area (\#89) as well as Peace River - Dunvegan, Peace River - Smoky Junction and Smoky River ESAs

ESA: PARKLAND; DRY MIXEDWOOD; BOREAL

Area (ha): 10687 (additional Parkland type habitat in Dry Mixedwood portion)

Location:

- Peace River Valley

- NTS Map Sheet: 84C, 83M, 83N, 84D

Municipality: MD of Saddle Hills; MD of Peace; MD of Fairview; MD of Spirit River; MD of Birch Hills; MD of Northern Lights; MD of East Peace; MD of Mackenzie; Municipality of Wood Buffalo

Significance: National

- one of the most diverse and productive river valleys in the Parkland of Canada

- the Peace River is a nationally significant waterway which supplies water to the PeaceAthabasca Delta, one of the largest freshwater deltas in the world 
Description:

- the river valley provides key year round habitat for Moose, Elk and deer

- significant habitat for rare birds of prey such as the Golden Eagle, Bald Eagle and Osprey

- high species diversity of fish

- fisheries resources include Lake Whitefish, Mountain Whitefish, Bull Trout, Northern Pike, Goldeye, Walleye, Yellow Perch, Burbot

- Bull Trout (being considered for COSEWIC listing) overwinter in the river

- Northern Squawfish are present only in the Peace River

- rare Largescale Suckers are also found in the river (distribution in Alberta is restricted to the Peace River drainage system)

- important waterfowl habitat

- Poston lists as provincially significant geese staging habitat

- critical semi-aquatic furbearer habitat

- the river valley is an important movement corridor

- Wandering and Red-sided Gartersnakes and hibernaculum are common along the banks of the river

- diverse vegetation community types occur along river

- south facing slopes support typical prairie vegetation

- recreation opportunities and wilderness areas exist all along the river for camping, canoeing, hiking and fishing

- south facing slopes support typical prairie and parkland vegetation such as aspen, grasses and cacti, the microclimate at Dunvegan (TWP80-RG4 - W6) results in this warm dry community of species such as cacti, Western Meadowlarks and Savannah Sparrows

- fossil beds are abundant in bedrock exposures along the valley walls

- Dunvegan, Peace Smoky Islands and Shaftesbury Islands Natural Areas are located within the Peace River valley

Potential to Contribute to Level 1 Natural History Theme Representation:

Crown lands have excellent potential for contributing to the following Level 1 NHTs that are currently underrepresented in protected areas: Exposed Slope, Protected Slope, and Floor/Stream.

Recommendations:

- All crown lands should be maintained in their natural state 



\section{PART 3 \\ Conclusion}





\section{Conclusion}

This report identifies priority sites for possible protected areas in the Parkland Natural Region These were identified using available information such as land ownership and levels of disturbance. This information was then intersected in a GIS environment with significance levels as identified through ESA studies. The priority sites are those that could make significant contributions to Level 1 Natural History Theme targets. Special features and themes are mentioned where the information is available, but many will not be included in protected areas if these are chosen based only on landscape representation criteria.

An overview of the Parkland Natural Region shows that extensive areas are no longer in native vegetation and remnant areas are becoming "islands". Some connecting corridors remain, particularly along rivers, but they too are progressively being fragmented. Of the three Parkland subregions in Alberta, the Central Parkland is the largest; the Foothills and Peace River Parkland are both comparable in size and considerably smaller. Despite this, the largest remaining native parkland block is within the Foothills Parkland. Due to the levels of disturbance and the limited crown land in the Natural Region, there are very few opportunities to establish extensive protected areas in the Parkland.

In the Central Parkland, there are opportunities for maintaining large blocks, especially in the Wainwright, Rumsey and Sounding Lake areas. There are also opportunities to improve connectivity in sand plain areas and river valleys. There is very little native habitat remaining on glacial lake and moraine sites. Even including private land and areas outside the natural region but with similar vegetation, several Level 1 themes cannot be achieved.

The largest remaining block in the Parkland Region is the Highwood-Chaffen site in the Foothills Parkland Subregion. At over $700 \mathrm{sq}$. km. it is a sizeable block, but includes areas atypical of the subregion and is in places, fragmented. There are opportunities here to fill Ridge/Valley Wall Level 1 targets, but the remainder of the Level 1 theme targets can likely not be achieved.

The Peace River Parkland Subregion is the most highly impacted. There are no sizeable blocks remaining and a limited area of suitable crown lands are available for inclusion in a provincial protected areas program. Even if all available lands are included, including areas outside the natural region but with similar vegetation, most Level 1 NHT targets will not be met.

Reviewing available information on the Parkland shows that the region has changed substantially Extensive loss of habitat and fragmentation of those remaining is reflected in the loss of species. Changes in levels and timing of key ecosystem processes and loss of continuity of natural habitats further magnify the impacts of habitat loss. The integrity of the Parkland landscape has been compromised. Establishing protected areas is a central component to restoring the integrity of the Parkland landscape and the species that use it and move through it. A protected areas system alone, however, is not enough. Areas of remaining native vegetation outside protected areas should also be maintained, and restoration of corridors and habitat blocks is required. This is the domain of the many individuals, groups, agencies and industries who are presently working together to restore and conserve native ecosystems. 


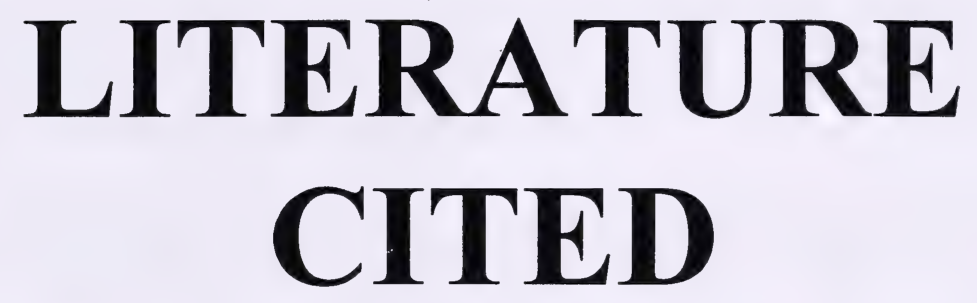


AAFC. 1995. Soil Landscapes of Canada, Version 2.1. National Soil Database, Agriculture and Agri-Food Canada.Achuff, P.L., J. Godfrey and W. Wallis. 1988. Natural Regions of Alberta: Annotated Bibliography. Protected Areas Report No. 4. Prepared for Alberta Recreation and Parks, Edmonton, AB., 112 pp.

Achuff, P.L. 1992. Natural Regions, subregions and Natural History Themes of Alberta: A classification for protected areas management. Report No. 2. Prepared for Parks Services and Natural \& Protected Areas, Alberta Government. Revised and updated December 1994

Achuff, P.L., and C. Wallis. 1992. Natural Regions and Natural History Themes: Targets for Alberta. Protected Areas Report No.3. Prepared for Alberta Tourism, Parks and Recreation and Alberta Forestry, Lands and Wildlife, Edmonton, AB., 71 pp.

Adams, B.W., W. Willms and M. Powell. 1993. Sustainable rangeland management--aligning livestock with the ecosystem. In: Proceedings of the International Workshop on Sustainable Land Management for the 21st Century (Volume 2: plenary papers). University of Lethbridge. Lethbridge, Canada. June 20-26, 1993.

AEP. 1996. The Status of Alberta Wildlife. Prepared by Wildlife Management Division; Natural Resources Service; Alberta Environmental Protection; Edmonton, Alberta. 44pp.

AFGA. 1993. Final Report: Operation Burrowing Owl, Alberta. Prepared by the Alberta Fish and Game Association. 19pp + appendices.

AFRD. 1992. GIS data re. "southern region native prairie vegetation". Prepared by Alberta Agriculture, Food and Rural Development. Hardcopy map scale 1:350,000.

AHJV. 1989 (January). The Alberta Habitat Joint Venture--A Planning Document. Prepared by Alberta Forestry, Lands and Wildlife; Canadian Forestry Service; Alberta Agriculture and Ducks Unlimited Canada.

Alberta Energy and Utilities Board (EUB). 1996. Alberta's energy resources: 1995 in review. Website addresses@http://www.eub.gov.ab.ca/bbs/inf/stat/st-96-40.b.html. and http://borg.energy.gov.ab.ca/dept/annrp.htm\#Energy and the enviro.

Alberta Environmental Protection. 1994a. Alherta's State of the Environment Comprehensive Report. Prepared by Dept. of Environmental Protection; Edmonton, AB. 119pp.

Alberta Environmental Protection [AEP]. 1994b. Alberta Protected Areas System Analysis (1994). Report 3: Revised by Achuff December 7, 1994; Edmonton, Alberta.

Alberta Environmental Protection. 1995 (August). Alberta's threatened wildlife. Brochure prepared by Natural Resources Service

Alberta Environmental Protection. 1996 (July). Selecting protected areas: the Foothills Natural Region of Alberta. Prepared for the Special Places Provincial Coordinating Committee. $77 \mathrm{pp}$. + maps and photos. 
Alberta Environmental Protection. 1996a. Alberta 1996 State of the Environment Report: Aquatic Ecosystems. Draft report No. 4. Prepared by Strategic \& Regional Support Division, Alberta Environmental Protection.

Alberta Forestry, Lands and Wildlife. n.d. Alberta's Landowner Habitat Program. Brochure prepared by the Fish and Wildlife Division.

Alberta Forestry, Lands and Wildlife. 1990. Alberta's threatened wildlife-Piping Plover. Brochure prepared by the Fish and Wildlife Division.

Alberta Forestry, Lands and Wildlife. 1991. The status of Alberta wildlife. Prepared by Wildlife Management Branch, Fish and Wildlife Division, Edmonton.

Alberta Prairie Conservation Forum. 1995 (November). Prairie Conservation. A bulletin from the Alberta Prairie Conservation Forum. 4pp.

Alberta Soil Survey Unit Staff. 1991. Soil landscapes of Canada-Alberta; Soil landscapes polygon attribute digital data; CanSIS No. AL088200, version 91.11.30; CLBRR Archive, Agriculture Canada, Research Branch, Ottawa, Canada (CLBRR Contribution No. 91-106D).

Alberta Water Resources Commission. 1987. Drainage potential in Alberta: an integrated study. Prepared by AWRC in concert with Alberta Departments of Agriculture, Environment and Forestry, Lands and Wildlife.

Alberta Water Resources Commission. 1993a. Beyond prairie potholes: a draft policy for managing Alberta's peatlands and non-settled area wetlands. $15 \mathrm{pp}$.

Alberta Water Resources Commission. 1993b. Wetland management in the settled area of Alberta: an interim policy. $14 \mathrm{pp}$.

Anderson, M.G., R.B. Fowler and J.W. Nelson. 1995. Northern grassland conservation and the Prairie Joint Ventures. In. Transactions of the Sixtieth North American Wildlife and Natural Resources Conference, March 24-29, 1995; Minneapolis, Minn.; pp404-412.

ANHIC. 1996a. Alberta Natural Heritage Information Centre (files). Recreation \& Protected Areas Division, Alberta Environmental Protection.

ANHIC. 1997. Digital database for nationally; provincially and internationally significant ESAs in Alberta. Recreation \& Protected Areas Division, Alberta Environmental Protection.

Avian Science and Conservation Centre. 1996. Saving the Loggerhead Shrike. Recovery-An Endangered Species Newsletter; Fall issue; Canadian Wildlife Service, Ottawa.

Banfield, A.W.F. 1974. The Mammals of Canada. University of Toronto Press, Toronto, Ontario. 
Baydack, R.K., J.H. Patterson, C. Rubec, A. Tyrchniewicz and T.W. Weins. 1995. Management challenges for Canadian prairie grasslands in the 21st century. In. Transactions of the Sixtieth North American Wildlife and Natural Resources Conference, March 24-29, 1995; Minneapolis, Minn.; pp386-396.

Bentley. 1988 (December). Overview of agriculture in the prairie-parkland. Address given to the annual joint meeting of the Public Advisory Committees of the Environment Council of Alberta., Edmonton. 36pp.

Bentz, J.A., Saxena, A. and T.T. Normand. 1995. Environmentally Significant Areas Inventory. Foothills Natural Region, Alberta. Geowest Environmental Consultants Ltd., Edmonton, AB., 142 pp. + Appendices, + Map.

Bird, R.D. 1961. Ecology of the aspen parkland of Western Canada in relation to land use. Can. Agric. Publ. 1066:(II)I,X, 155pp.

Bjorge, R.R. 1987. Bird kill at an oil industry flare stack in northwest Alberta. Can. Field Nat. 101(3):346-350.

Brace, R.K. and G.W. Pepper. 1984. Impact of agricultural drainage on wildlife. Western Provincial Conference on Soil and Water Management. 22pp.

Bradley, C. and C. Wallis. 1996 (February). Prairie ecosystem management: an Alberta perspective. Published by Prairie Conservation Forum, Occasional Paper No. 2; 29pp.

Brechtel, S.H. 1981. A status report, management proposal and selected bibliography for the White Pelican, Double-crested Cormorant and Great Blue Heron in Alberta - 1980. Unpubl. report, prep. for Fish and Wildlife Division, Alberta Energy and Natural Resources. 113pp.

Bredy, J. 1995 (May). Waterfowl Breeding Population Survey: southern and central Alberta. Data supplied by the United States Fish \& Wildlife Service, Canadian Wildlife Service, Alberta Fish \& Wildlife Division.

Bromley, M. 1985. Wildlife management implications of petroleum exploration and development in wildland environments. Gen. Tech. Report INT-191. Ogden, UT: U.S. Dept. of Agric., Forest Service, Intermountain Research Station, 42pp.

Brown, M. and J.J. Dinsmore. 1986. Implications of marsh size and isolation for marsh bird management. J. Wildl. Manage. 50:392-397.

Brusnyk, L., D. Westworth, K. Egan, A. McCann, L. Knapiak, and C. Schreiner. 1991. Environmentally sensitive areas study: County of Leduc. Prepared for the Edmonton Metropolitan Regional Planning Commission, Edmonton.

Burnett, J.A., C.T. Dauphine Jr., S.H. McCrindle and T. Mosquin. 1989. On the brink: endangered species in Canada. Western Producer Prairie Books, Saskatoon, Sask. 
Campbell, R.W., N.K. Dawe, I. McTaggart-Cowan, J.M. Cooper, G.W. Kaiser and M.C.E. McNall. 1990. The Birds of British Columbia. Vol. I. Introduction and Loons through Waterfowl. Published by the Royal British Columbia Museum in association with Environment Canada, Canadian Wildlife Service.

Campbell, R.W., N.K. Dawe, I. McTaggart-Cowan, J.M. Cooper, G.W. Kaiser and M.C.E. McNall. 1990a. The Birds of British Columbia. Vol. II. Diurnal Birds of Prey through Woodpeckers. Published by the Royal British Columbia Museum in association with Environment Canada, Canadian Wildlife Service.

Canadian Council on Ecological Areas. 1992. A Framework for Developing a Nation-wide System of Ecological Areas. Part 1: A Strategy. Can. Council on Ecol. Areas, Ottawa, ON., $10 \mathrm{pp}$.

Canadian Environmental Advisory Council. 1991. A Protected Areas Vision for Canada. Canadian Environmental Advisory Council, Environment Canada, Ottawa. 88pp.

Christiansen, P.A. 1990. Alien species cover on the perimeter of two northwest Iowa prairies. In. Proceedings of the 12th North American Prairie Conference; August 1990; Cedar Falls, Iowa.

Cooperrider, A.Y. 1994 (Summer). Saving Nature's Legacy. How can our public and private lands best be managed to protect biological diversity? Defenders 69(3):17-24.

COSEWIC. 1997 (April). Canadian species at risk. Prepared by the Committee on the Status of Endangered Wildlife in Canada.

Cottonwood Consultants Ltd. 1983. A Biophysical Systems Overview for Ecological Reserves Planning in Alberta. Prepared for Alberta Recreation and Parks, Edmonton, AB., 365 pp.

Cottonwood Consultants Ltd. 1987a. M.D. of Pincher Creek Environmentally Significant Areas. Prepared for Alberta Forestry, Lands \& Wildlife; Edmonton. Vol. 1 (34pp) and Vol. 2 (37pp).

Cottonwood Consultants Ltd. 1987b. Environmentally Significant Areas in the Oldman River Region: M.D. of Cardston. Prepared for Alberta Forestry, Lands \& Wildlife; Edmonton. (38pp) and Vol. 2 (26pp).

Cottonwood Consultants Ltd. 1991a. Lower Red Deer River Environmentally Significant Areas. Prepared for Alberta Forestry, Lands \& Wildlife; Edmonton. 66pp.

Cottonwood Consultants Ltd. 1991b. M.D. of Starland No. 47-- Environmentally Significant Areas. Prepared for Alberta Forestry, Lands \& Wildlife; Edmonton. 42pp.

Cottonwood Consultants Ltd. 1995. Environmentally Significant Areas of the Lloydminster area, Alberta and Saskatchewan. Prepared for Nature Conservancy of Canada and Husky Oil Operations, Calgary. 
Coupland, R.T. 1973. A Theme Study of Natural Grasslands in Western Canada. A report to National and Historic Parks Branch, Canada Department of Indian Affairs and Northern Development.

Court, G., S. Brechtel, G. Erickson and B Treichel. 1996. The future of the Peregrine Falcon (Falco peregrinus anatum) population in Alberta. In: Proceedings of the Fourth Prairie Conservation and Endangered Species Workshop. Edited by W.D. Willms and J.F. Dormaar. Provincial Museum of Alberta, Natural History Occasional Paper No. 23.

Cox, K.W. 1993. Wetlands--a celebration of life. North American Wetlands Conservation Council (Canada). Issues Paper, No. 1993-1.

Creasey, R. 1997 (February). News release by the Prairie Conservation Forum. Release dated Wednesday, 5 February, 1997.

Dauphine, C. 1996. Broadening the scope of recovery. Recovery-An Endangered Species Newsletter; Fall issue; Canadian Wildlife Service, Ottawa.

De Smet, K.D. and W.S. Miller. 1989. Status report on the Baird's sparrow (Ammodramus bairdii) in Canada. Prepared for the Committee on the Status of Endangered Wildlife in Canada. 26pp.

Desgranges, J.L. and P. Laporte. 1979. Second tour of inspection of Quebec heronries, 1978. Canadian Wildlife Service, Progress Note No. 105. 12pp.

Diamond, J.M. 1976. Island biogeography and conservation: Strategy and limitations. Science 193:1027-1029.

Diamond, A.W. 1993. Integration of ecological and biodiversity concerns into sustainable land management. In: Proceedings of the International Workshop on Sustainable Land Management for the 21 st Century (Volume 2: plenary papers). University of Lethbridge. Lethbridge, Canada. June 20-26, 1993.

DU \& ENR. n.d. Proposal for a five-year co-operative waterfowl habitat program emphasizing key wetlands in Alberta. A joint proposal by Ducks Unlimited and Energy \& Natural Resources.

Eagles, P.F.J. 1984. The Planning and Management of Environmentally Sensitive Areas. Longman, Harlow, U.K., 160 pp.

Easterly, T.G. and R.J. Guenzel. 1992. Responses of pronghorn to petroleum development on crucial winter range. Proceedings of the 15th Biennial Pronghorn Antelope Workshop; Rock Springs, Wyoming; June 8-11, 1992.

Egler, F. 1977. The Nature of Vegetation: Its Management and Mismanagement. Aton Forest, Norfolk, CT. 
Energy Resources Conservation Board (ERCB). 1994 (December 31). Designated Oil and Gas Fields, Oil Sands Deposits, Main Pipelines, Refineries and Gas Processing Plants. MAP ERCB-90, $($ Scale $=c a \cdot 1: 1,500,000)$. Calgary, $\mathrm{AB}$

Environment Canada. 1986a. Canada's environment--an overview. Prepared by Environment Canada and Statistics Canada.

Environment Canada. 1991. The state of Canada's environment--1991. Government of Canada. Ottawa.

Environment Canada. 1994 (December). Prairie Canada Waterfowl Population Surveys. Prepared by Environmental Conservation Branch, Canadian Wildlife Service, Winnipeg.

ERCB. 1992. Petroleum activity on native prairie--guidelines for surface disturbances. Prepared by Special Areas Board; Energy Resources Conservation Board; Alberta Environment; Alberta Forestry, Lands and Wildlife; and Alberta Energy.

Finch, D.M. 1992. Threatened, endangered and vulnerable species of terrestrial vertebrates in the Rocky Mountain Region. U.S.D.A. Forest Service, Gen. Tech. Rep. RM-215; Rocky Mountain Forest and Range Experiment Station; Fort Collins, Colorado.

Finlay, C.J. 1996. Dear diary--what the journals of the fur traders tell us about a land we have lost. Environment Views 19(5):11-14.

Fisher, C.C., and W. Roberts. 1994. Herpetofaunal investigations on North American Waterfowl Management Plan properties in Alberta - 1994. 1) Aspen parkland grassland restoration. 2) Medicine Wheel Landscape. Alberta NAWMP Centre. NAWMP-010. Edmonton, Alberta. 23pp.

Geist, V. 1996. Buffalo Nation-History and Legend of the North American Bison. Fifth House Publishers; Saskatoon, Saskatchewan and Calgary, Alberta.

Geowest Environmental Consultants Ltd. 1996. Environmentally Significant Areas Inventory: Grassland and Parkland Natural Regions, Alberta. Prepared for Alberta Environmental Protection. $121 \mathrm{pp}+$ appendices.

Godfrey, W.E. 1986. The Birds of Canada. Revised edition. National Museum of Natural Sciences, National Museums of Canada, Ottawa, Canada.

Gollop, J.B. 1978. Changes in songbird populations since the mid-1940s in the prairie provinces. Pp. 78-103. In: Davies, W.A. (ed.). Nature and change on the Canadian plains. Can. Plains Proceedings 6; Can. Plains Res. Centre; Univ. Regina; Regina, Saskatchewan.

Goossen, J.P., S. Brechtel, K.D. De Smet, D. Hjertaas and C. Wershler. 1993. Canadian Baird's sparrow recovery plan. Recovery of Nationally Endangered Wildlife Report No. 3. Ottawa: Canadian Wildlife Federation. 28pp. 
Goossen, P. and B. Dale. 1996. Delisting not yet a conservation victory. Recovery-An Endangered Species Newsletter; Fall issue; Canadian Wildlife Service, Ottawa.

Government of Alberta. 1995 (March). Special Places 2000: Alberta's Natural Heritage. Policy and Implementation Plan.

Grilz, P.L. and J.T. Romo. 1995. Management considerations for controlling smooth brome in fescue prairie. Natural Areas Journal 15(2):148-156.

Grumbine, R.E. 1992. Ghost Bears. Exploring the Biodiversity Crisis. Island Press, Washington, D.C., 294 pp.

Hardy, RM. \& Associates Ltd. 1975. Preliminary report on effects of pipeline construction on grasslands of southern Alberta. Prepared for the Research Secretariat of Alberta Department of the Environment.

Herkert, J. R. 1994. The effects of habitat fragmentation on midwestern grassland bird communities. Ecological Applications 4(3):461-471.

Heyer, R. 1996 (April). Vanishing amphibians: a real problem? World Conservation, pp 1011. Published by IUCN, The World Conservation Union.

Hjertaas, D. 1996. Status of Burrowing Owl and of recovery efforts in Canada. In: Proceedings of the Fourth Prairie Conservation and Endangered Species Workshop. Edited by W.D. Willms and J.F. Dormaar. Provincial Museum of Alberta, Natural History Occasional Paper No. 23.

Hjertaas, D., S. Brechtel, R. Jones, R. Edwards and C. Schroeder. 1993. National recovery plan for the greater prairie chicken. Report No. 5. Ottawa: Recovery of Nationally Endangered Wildlife Committee, 18pp.

Hjertaas, D., S. Brechtel, K. De Smet, O. Dyer, E. Haug, G. Holroyd, P. James and J. Schmutz. 1995. National recovery plan for the hurrowing ow $l$. Report No. 13. Ottawa: Recovery of Nationally Endangered Wildlife Committee, 33pp.

Hobbs, R.J. and L.F. Huenneke. 1992. Disturhance, diversity, and invasion: implications for conservation. Conserv. Biol. 6(3):324-337

Holroyd, G.L., H.L. Dickson, M. Regnier and H.C. Smith. 1993. Proceedings of the third prairies conservation and endangered species workshop. Natural History Occasional Paper No. 19. Provincial Museum of Alberta. Edmonton.

Horejsi, B.L. 1995. Habitat Fragmentation by the Oil and Gas Industry in Alberta and British Columbia: Its Impact on Wildlife. Western Wildlife Environments Consulting Ltd., Calgary, AB., $10 \mathrm{pp}$. 
Howe, M.A. 1987. Wetlands and waterbird conservation. Amer. Birds 41:204-209.

Howe, M.A., P.H. Geissler and B.A. Harrington. 1989. Population trends of North American shorebirds based on the International Shorebird Survey. Biol. Conserv. 49:185-199.

Hummel, M. (editor). 1989. Endangered Spaces. The Future for Canada's Wilderness. Key Porter Books, Toronto, ON. 288 pp.

Hummel, M. (editor). 1995. Protecting Canada's Endangered Spaces. An Owner's Manual. Key Porter Books, Toronto, ON., 251 pp.

Ignatiuk, J. and D.C. Duncan. 1995 (September). Wetland loss in Aspen Parkland of Saskatchewan. Blue Jay 53(3):129-133.

IISD. 1994. Sustainability of Canada's Agri-Food system-a prairie perspective. Published by the International Institute for Sustainable Development (IISD) for the Faculty of Agricultural and Food Sciences, University of Manitoba.

Infotech. 1989. Environmentally significant areas: County of Strathcona and M.D. of Sturgeon. Prepared for the Edmonton Metropolitan Regional Planning Commission, Edmonton.

James, P.C. 1993. Habitat fragmentation and burrowing owls in Saskatchewan. In. Proceedings of the Third Prairie Conservation and Endangered Species Workshop. Provincial Museum of Alberta Nat. Hist. Occas. Paper No. 19., pp.193-194.

Jennersten, O. 1988. Pollination in Dianthus deltoides (Caryophyllaceae): effects of habitat fragmentation on visitation and seed set. Conservation Biology 2:359-366.

Johns, B., E. Telfer, M. Cadman, D. Bird, R. Bjorge, K. De Smet, W. Harris, D. Hjertaas, P. Laporte and R. Pittaway. 1994. National recovery plan for the loggerhead shrike. Report No. 7. Ottawa: Recovery of Nationally Endangered Wildlife Committee, 32pp.

Johnsgard, P.A. 1981. The plovers sandpipers and snipes of the world. University of Nebraska Press, Lincoln.

Johnston, A. and S. Smoliak. 1976 (September). Settlements of the grasslands and the Greater Prairie Chicken. Blue Jay 34(3):153-156.

Kavanagh, K., T. Iacobelli and S. Rowe 1994. A Protected Areas Gap Analysis Methodology: Planning for the Conservation of Biodiversity: World Wildlife Fund Canada, Toronto, ON. $68 \mathrm{pp}$.

Kavanagh, K., R. Noss and T. Iacobelli. 1995. Building the Ark: the Science Behind the Selection of Protected Areas. Pp. 2-8, in: Hummel, M. (editor). Protecting Canada's Endangered Spaces. An Owner's Mamual. Key Porter Books, Toronto, ON., 251 pp. 
Kerr, D.S., L.J. Morrison and K.E. Wilkinson. 1993. Reclamation of native grasslands in Alberta: A review of the literature. Alberta Land Conservation and Reclamation Council Report No. RRTAC 93-1. Edmonton.

Kirkpatrick, J.B., and M.J. Brown. 1994. A comparison of direct and environmental domain approaches to planning reservation of forest higher plant communities and species in Tasmania. Conservation Biology 8:217-224.

Lamoureux, R.J., G.G. Chow and B.O.K. Reeves. 1983. Environmentally Significant Areas of the Calgary Region. Prepared for the Calgary Regional Planning Commission. 257pp.

Land Information Services. 1994. Natural Regions and Subregions of Alberta. Map produced by Alberta Environmental Protection. Edmonton, Alberta.

Lewis, K.T. 1993. Gap Analysis Workbook for Regional Protected Areas Teams. (Working Draft - June 1993). A Protected Areas Strategy for British Columbia. Province of British Columbia, Victoria, B.C., 43 pp. + 14 Appendices.

McNicholl, M.K. 1988. Ecological and human influences on Canadian populations of grassland birds. In. Ecology and Conservation of Grassland Birds; ICBP Technical Publication No. 7.

Microsoft Internet Explorer. 1996. Endangered species. Internet addresses are: (1) http://www-nais.ccm.emr.ca/schoolnet/issues/risk/birds/ebirds.html; (2) http://www.afternet.com/ teal/shawk.html

Mills, L.S. 1995. Edge effects and isolation: Red-backed voles on forest remnants. Conservation Biology 9(2):395-403.

Mitchell, G.J. 1980. The Pronghorn Antelope in Alberta. Dept. of Biol., University of Regina; Regina, Sask., 165pp.

Monds, S. 1995. Basic principles--planning for species needs within a landscape planning framework. Environment Canada.

Nagy, J.A. and J.R. Gunson. 1990. Management plan for grizzlies in Alberta. Wildlife Management Planning Series No. 2. Alberta Forestry, Lands and Wildlife; Fish and Wildlife Division.

National Energy Board. 1996 (May). Express Pipeline Project--Report of the Joint Review Panel. Prepared by the NEB and the Canadian Environmental Assessment Agency. 197pp.

NAWMP. 1996. North American Waterfowl Management Plan. 1986 to 1996: 10th Anniversary Report-Canada. 16pp. Prepared by NAWMP and its Partners.

Nelson, J.W. 1989. The duck depression of the 1980s: an agenda for recovery. A Ducks Unlimited Discussion Paper. Ducks Unlimited, Inc. 
Nelson, J.G. 1993. Beyond Parks and Protected Areas. From public lands and private stewardship to landscape planning and management. Pp. 45-56, In: Dearden, P., and Rollins, R. (editors). Parks and Protected Areas in Canada. Planning and Management. Oxford University Press, Toronto, ON. 336 pp.

Nelson, J.S. and M.J. Paetz. 1992. The Fishes of Alberta. 2nd edition. University of Alberta Press and the University of Calgary Press. $437 \mathrm{pp}$.

Nietfeld, M., J. Wilk, K. Woolnough and B. Hoskin. 1985. Wildlife habitat requirement summaries for selected wildlife species in Alberta. Alberta Forestry, Lands and Wildlife. Fish and Wildlife Division.

Noss, R.F. 1995. Maintaining Ecological Integrity in Representative Reserve Networks. Discussion Paper. World Wildlife Fund Canada/WWF-U.S., Toronto, ON./Washington, D.C., 77 pp.

Noss, R.F., and A.Y. Cooperrider. 1994. Saving Nature's Legacy. Protecting and Restoring Biodiversity. Island Press, Washington, D.C., 416 pp.

Ockenfels, R.A., C.L. Ticer, A. Alexander and J.A. Wennerlund. 1996. A landscape-level Pronghorn habitat evaluation model for Arizona. Ariz. Game and Fish Dep. Tech. Rep. 19, Phoenix. 50pp.

O'Leary, D. and D. Downing. 1990. Eastern Irrigation District: an analysis of wetland habitat change. Volume 1. Alberta Forestry, Lands and Wildlife. 30pp.

Ostlie, W.R., R.E. Schneider, J.M. Aldrich, T.M. Faust, R.L.B. McKim and H.M. Watson. 1996. The status of biodiversity in the Great Plains. The Nature Conservancy, 1815 North Lynn Street, Arlington, VA. USA.

Owens, R.A. and M.T. Myres. 1973. Effects of agriculture upon populations of native passerine birds of an Alberta fescue grassland. Can. J. Zool. 51:697-713.

Partners in flight - Canada. 1996. Framework for landbird conservation in Canada. Canadian landbird Conservation Working Group. Hull, Quebec. 23pp.

Patriquin, D.L. 1993. An overview of priority vertebrate species and habitats in relation to NAWMP Program Delivery in Alberta. D.A. Westworth and Associates Ltd. Alberta NAWMP Centre. NAWMP-006. Edmonton, Alberta. 77pp.

PHJV. 1993 (December). PHJV Progress Summary. Prepared by Prairie Habitat Joint Venture (PHJV), a Key Target Area of the North American Waterfowl Management Plan.

PHJV. 1995. Prairie Habitat Joint Venture: Conserving an International Resource, 19861994. Prepared under the auspices of the North American Waterfowl Management Plan. 
Poston, B., D.M. Ealey, P.S. Taylor and G.B. McKeating. 1990. Priority migratory bird habitats of Canada's Prairie Provinces. Canadian Wildlife Service. Environment Canada. $107 \mathrm{pp}$.

Powell, G.L. and A.P. Russell. 1996. Alberta's amphibians and reptiles: current research and conservation issues. In: Proceedings of the Fourth Prairie Conservation and Endangered Species Workshop. Edited by W.D. Willms and J.F. Dormaar. Provincial Museum of Alberta, Natural History Occasional Paper No. 23.

Prairie Conservation Forum. 1996 (May). 1994-1995 Anmual Report. Alberta Environmental Protection.

Prairie Conservation Forum. 1997 (January). Alberta Prairie Conservation Action Plan. Published by the Prairie Conservation Forum, Lethbridge, Alberta. 27pp.

PrairiNet Webmaster. 1996. The National Grasslands System. A note from the prairiNet webmaster. $5 \mathrm{pp}$

Prescott, D.R.C. and A.J. Murphy. 1996. Habitat associations of grassland birds on native and tame pastures in the Aspen Parkland of Alberta. Alberta NAWMP Centre. NAWMP021. Edmonton, Alberta. 36 pp.

Prescott, D.R.C. and G.M. Wagner. 1996. Avian responses to implementation of a complementary/rotational grazing system by the North American Waterfowl Management Plan in southern Alberta: the Medicine Wheel Project. Alberta NAWMP Centre. NAWMP018. Edmonton, AB. 24pp.

RENEW. 1996. Fifth Annual Report: 1994/95. Recovery of Nationally Endangered Wildlife Secretariat, Canadian Wildlife Service. 35pp.

Roberts, W. 1992. Declines in amphibian populations in Alberta. In: Declines in Canadian amphibian populations: designing a national monitoring strategy. Occ. Pap. No. 76. Canadian Wildlife Service, Environment Canada, Ottawa. 120pp.

Russell, A.P. and A.M. Bauer. 1993. The amphibians and reptiles of Alberta. University of Calgary Press \& University of Alberta Press. 264pp.

Salt, W.R. and J.R. Salt. 1976. The birds of Alberta. Hurtig Publishers. Edmonton.

Samson, F. and F. Knopf. 1994. Prairie conservation in North America. BioScience 44(6):418-421.

Sauer, J. R., B. G. Peterjohn, S. Schwartz and J. E. Hines. 1996. The North American Breeding Bird Survey. Patuxent Wildlife Research Center, Laurel, MD. Website address: http://www.mbr.nbs.gov:80/bbs/bbs.html. 
Saxena, A., V. Chilsholm and J. Bentz. 1996. Ecologically significant areas inventory, Grassland and Parkland Natural Regions, Alberta. Prepared for Resource Data Division, Alberta Environmental Protection, Edmonton.

Schmutz, J.K. 1987. The effect of agriculture on Ferruginous and Swainson's hawks. J. Range Mgmt. 40(5):438-440.

Schmutz, J.K. 1990. Management plan for the ferruginous hawk in Alberta. World Wildlife Fund Canada and Alberta Fish and Wildlife Division. Unpublished report. 69pp.

Schmutz, J.K., S.H. Brechtel, K.D. De Smet, D.G. Hjertaas, C.S. Houston and G.L. Holroyd. 1994. National recovery plan for the ferruginous hawk. Report No. 11. Ottawa: Recovery of Nationally Endangered Wildlife Committee, 35pp.

Scobie, D. 1994. Annual Report of the Operation Grassland Community. Prepared for the Alberta Fish and Game Association. 11pp.

Semenchuk, G.P. (ed.) 1992. The Atlas of Breeding Birds of Alberta. Published by the Federation of Alberta Naturalists.

Shandruk, L. 1987. A review of habitat requirements and management priorities for the Canadian breeding population of Trumpeter Swans. In: Holroyd, G.L., W.B. McGillivray, P.H.R. Stepney, D.M. Ealey, G.C. Trottier and K.E. Eberhart. (eds.). Proceedings of the Workshop on Endangered Species in the Prairie Provinces. Occas. Paper No. 9, Provincial Museum of Alberta, Natural History. 367pp.

Shields, J.A. and J.D. Lindsay. 1990. Soil Landscapes of Canada-Alberta. Digital Map Data; Scale 1:1,000,000; CanSIS No. AL088200, version 91.11.30; CLBRR Archive, Agriculture Canada, Research Branch, Ottawa, Canada. (CLBRR Contribution No. 91-105D).

Sinclair, A.R.E., D.S. Hik, O.J. Schmitz, G.G.E. Scudder, D.H. Turpin and N.C. Larter. 1995. Biodiversity and the need for habitat renewal. Ecological Applications 5(3):579-587.

Slocombe, D.S. 1993. Implementing ecosystem-based management. BioScience 43(9):612622.

Smith, H.C. 1993. Alberta mammals--an atlas and guide. Provincial Museum of Alberta, Edmonton, Alberta.

Soper, J.D. 1964. The Mammals of Alberta. Queen's Printer, Edmonton.

Stelfox, J.B. (editor). 1995. Relationships between stand age, stand structure, and biodiversity in aspen mixedwood forests in Alberta. Jointly published by Alberta Environmental Centre (AECV95-R1), Vegreville, AB., and Canadian Forest Service (Project No. 0001A), Edmonton, AB., 308 pp. 
Strong, W.L., B.K. Calverley, A.J. Richard and G.R. Stewart. 1993 (June). Characterization of wetlands in the settled areas of Alberta. Prepared by Ecological Land Surveys Ltd. and Ducks Unlimited Canada.

Sweetgrass Consultants Ltd. 1988. Environmentally Significant Areas of the Counties of Lacombe and Stettler. Prepared for Alberta Forestry, Lands \& Wildlife; Edmonton. 33pp.

Sweetgrass Consultants Ltd. 1989. Environmentally Significant Areas of the County of Paintearth. Prepared for the Red Deer Regional Planning Commission and Alberta Forestry, Lands \& Wildlife; Edmonton. 25pp. + maps.

Sweetgrass Consultants Ltd. 1990. Environmentally Significant Areas of the County of Red Deer. Prepared for the Red Deer Regional Planning Commission, Red Deer.

Sweetgrass Consultants Ltd. 1991. Environmentally Significant Areas of the County of Mountain View. Prepared for Alberta Forestry, Lands \& Wildlife; Edmonton. 27pp.

Taylor, P.D., Fahrig, L., K. Henein and G. Merriam. 1993. Connectivity is a vital element of landscape structure. Oikos 68(3):571-573.

Tilman, D., R.M. May, C.L. Lehman and M.A. Nowak. 1994. Habitat destruction and the extinction debt. Nature 371(6492):65-66.

Trant, D., C. De Boer and K.Van Tighem. 1995. Environmental change around Waterton Lakes National Park. In. Environmental Perspectives--Studies and Statistics. National Accounts and Environmental Division, Statistics Canada.

Trottier, G.C. 1992. Conservation of the Canadian Prairie Grasslands: A Landowner's Guide. Canadian Wildlife Service. Environment Canada.

Turner, B.C., G.S. Hochbaum, F.D. Caswell and D.J. Nieman. 1987. Agricultural impacts on wetland habitats on the Canadian prairies, 1981-85. Transactions of the 52nd North American Wildlife and Natural Resources Conference, pp. 206-215.

Turner, B.C. and F.D. Caswell. 1989. Waterfowl population and habitat status. Ducks Unlimited Sixth International Waterfowl Symposium. Washington, D.C. pp 12-26.

Turner, B. and P. Pryor. 1992 (June). Alherla Walerfowl Status Report. Canadian Wildlife Service.

United States Department of Agriculture (USDA). 1993. Eastside Forest Ecosystem Health Assessment. Vol. 1: Executive Summary: USDA, National Forest System, Forest Service Research, 57 pp.

Usher, R. and J. Scarth. 1990. Alberta's wetlands: water in the bank. Published by Environment Council of Alberta. 37pp.

Van Tighem, K. 1989. Clots in nature's lifeblood. Borealis 1(2):35-41. 
Van Tighem, K. 1996. From wilds to weeds--Alberta's changing ecosystems. Environment Views 19(5):5-8.

Van Vuren, D. 1982. Comparative ecology of bison and cattle in the Henry Mountains, Utah. Pp 449-457 in L. Nelson, J.M. Peek and P.D. Dalke, editors. Proceedings of the wildlifelivestock relationships symposium. Forest, Wildlife and Range Experiment Station, University of Idaho, Moscow, Idaho.

van Zyll de Jong, C.G. 1983. Handbook of Canadian Mammals. National Museums of Canada, Ottawa, Canada.

Wallis, C. 1987. Critical, threatened and endangered habitats in Alberta. Provincial Museum of Alberta, Occas. Paper No. 9:49-63.

Wallis, C. 1989. Western blue flag--management plan. Prepared for World Wildlife Fund Canada, Prairie for Tomorrow. 37pp.

Wallis, C. 1990. Reconnainssance survey of saline wetlands and springs in the GrasslandParkland region of eastern Alberta. Prepared for World Wildlife Fund, Edmonton.

Webb, N.R. 1988. Studies on the invertebrate fauna of fragmented heathland in Dorset, U.K. and implications fro conservation. Biological Conservation 47:153-165.

Weins, T.W. 1996. Sustaining Canada's wildlife habitat. Draft report, Prairie Farm Rehabilitation Administration, Regina.

Wells, M.P. and K.E. Brandon. 1993. The principles and practice of buffer zones and local participation in biodiversity conservation. Ambio 22(2-3):157-162.

Wershler, C. 1990. Status of the Baird's sparrow in Alberta--1989. Prepared by Sweetgrass Consultants Ltd. for World Wildlife Fund, Canadian Wildlife Service and Alberta Fish and Wildlife Division.

Westworth, D.A. and Associates. 1993. Functions and values of Alberta's wetlands. Prepared for Wetlands Management Steering Committee; Edmonton, Alberta. 95pp.

Westworth, D.A. and L. Knapik. 1987. Significant natural features and landscapes of Strathcona County. Prepared for the Recreation and Parks, Strathcona County.

Wetlands for the Americas. n.d. Shorehirds and agriculture. Brochure prepared by Wetlands for the Americas, National Fish and Wildlife Foundation and the North American Waterfowl Management Plan.

Wickett, R.G., P.D. Lewis, A. Woodliffe and P. Pratt. 1992. Spirit of the Land, Our Prairie Legacy. Proceedings of the Thirteenth North American Prairie Conference, August 6-9, 1992, Windsor, Ontario. Department of Parks and Recreation; Windsor, Ontario. 
Wilcox, B.A. and D.D. Murphy. 1985. Conservation strategy: the effects of fragmentation on extinction. Amer. Naturalist 125:879-887.

Willms, W.D. and J.F. Dormaar (editors). 1996. Proceedings of the Fourth Prairie Conservation and Endangered Species Workshop. Provincial Museum of Alberta, Natural History Occasional Paper No. 23.

With, K.A. and T.O. Crist. 1995. Critical thresholds in species' responses to landscape structure. Ecology 76(8):2446-2459.

World Commission on Environment and Development (WCED). 1987. Our Common Future. Oxford University Press, Oxford, U.K., 400 pp.

World Wildlife Fund. 1988. Prairie Conservation Action Plan, 1989-1994. Prepared by the Wild West Steering Committee, World Wildlife Fund Canada. 38pp.

World Wildlife Fund. 1992. Canadian endangered species. Prepared by the Committee on the Status of Endangered Wildlife in Canada (COSEWIC). World Wildlife Fund, Toronto.

WWF. ca.1993. Burrowing owl at risk. Action Alert Bulletin prepared by World Wildlife Fund (WWF), Canada.

WWF. 1996. Endangered Spaces Progress Report: 95-96. No. 6. World Wildlife Fund Canada. 66pp. 



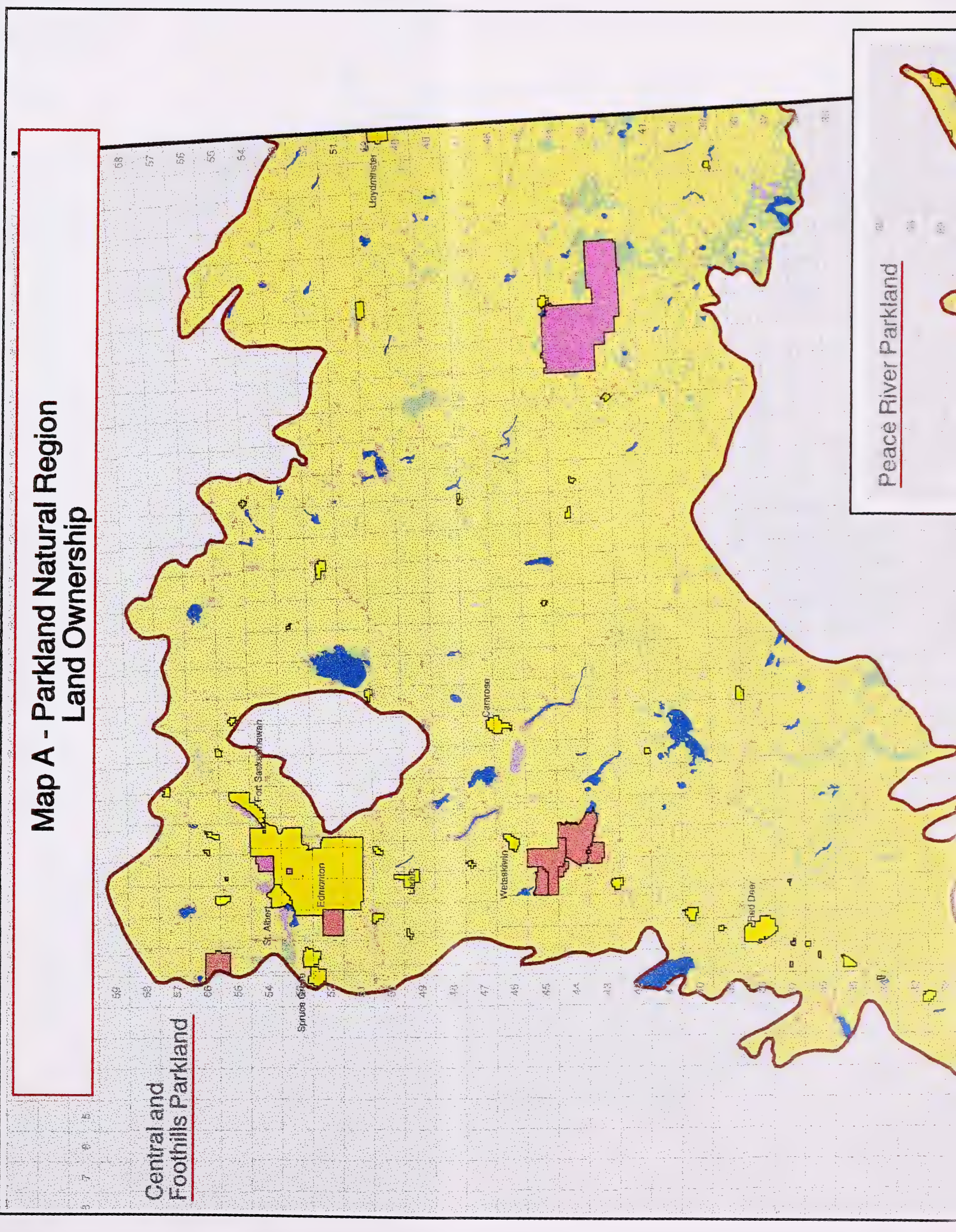



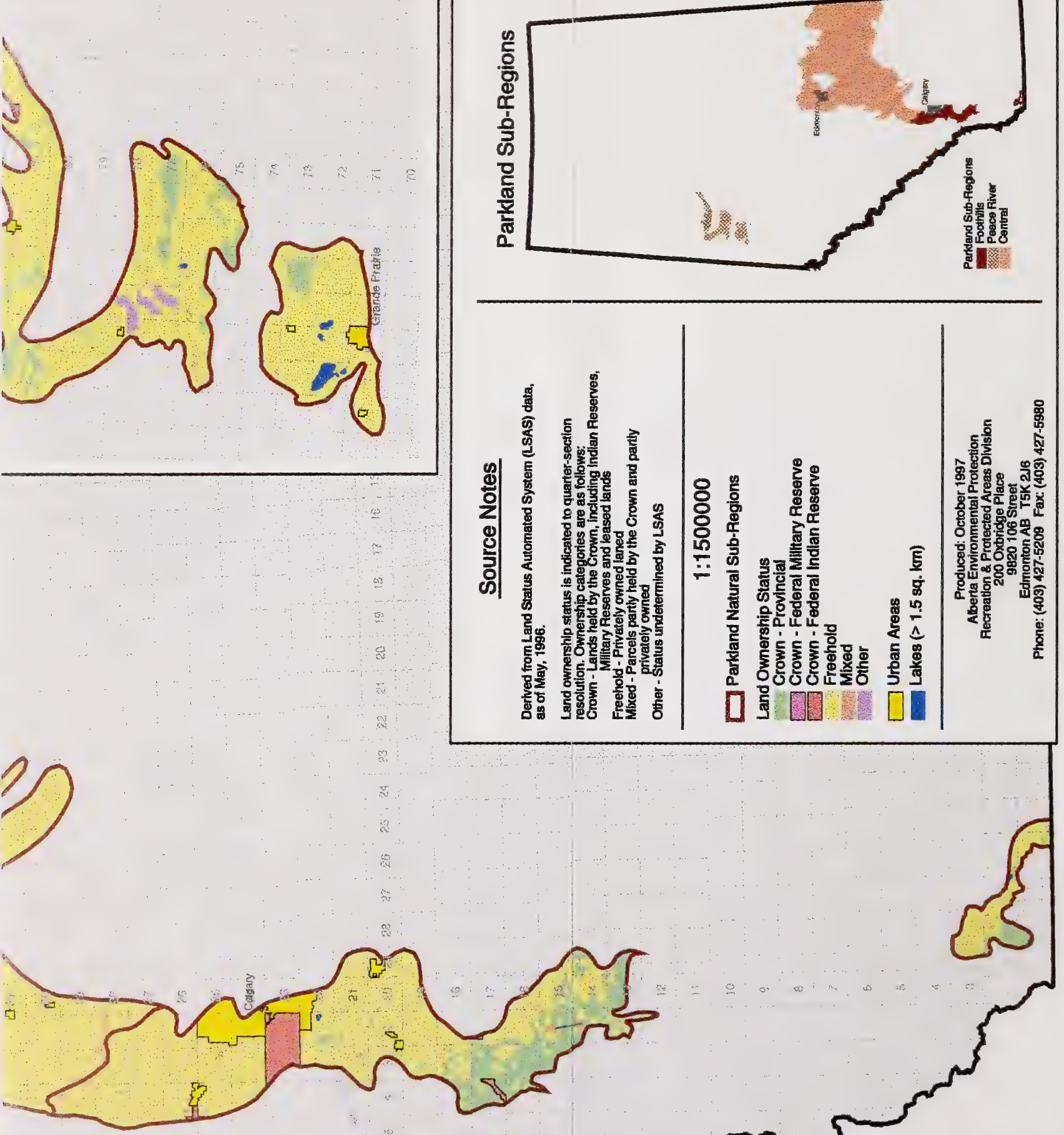


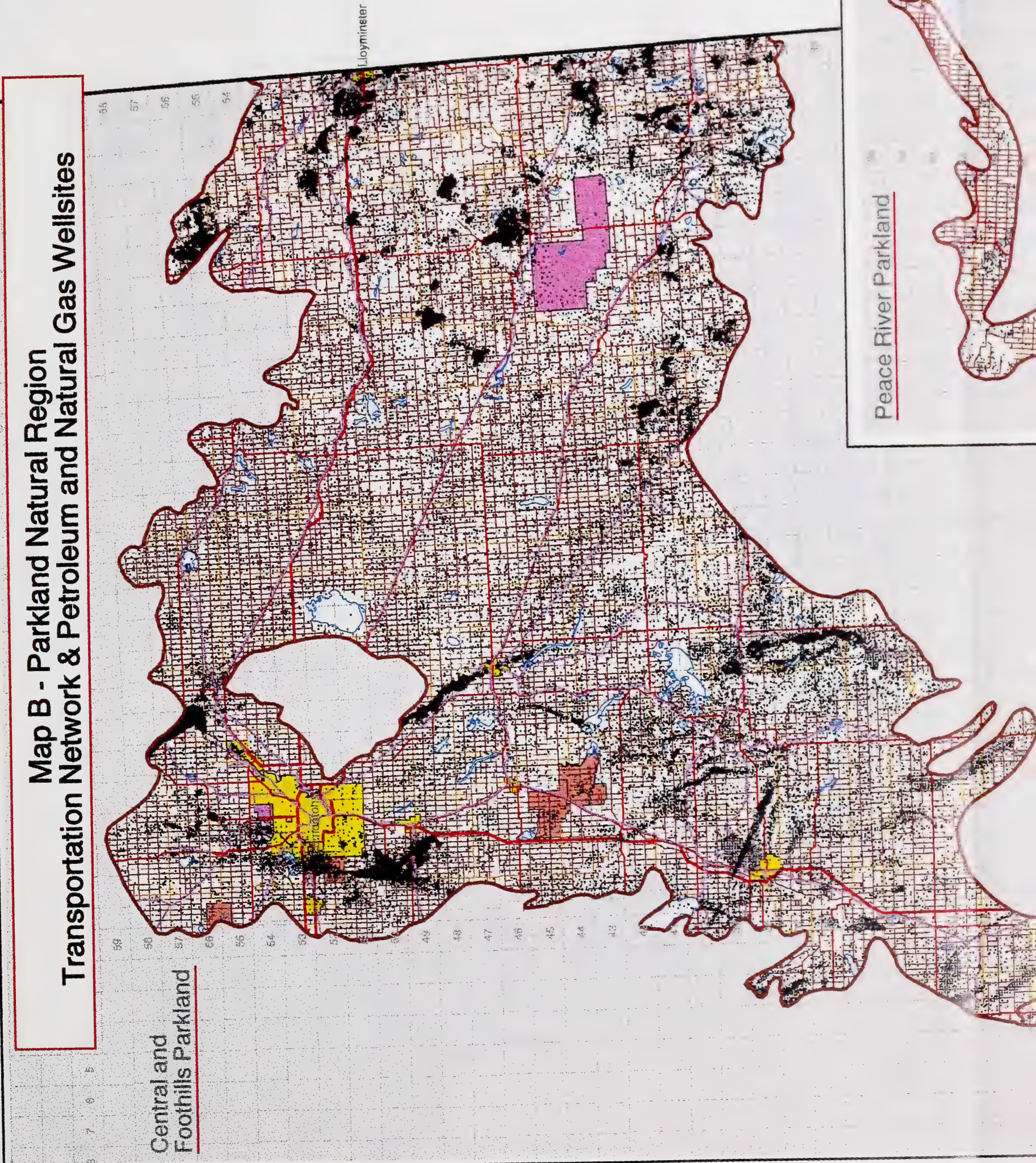



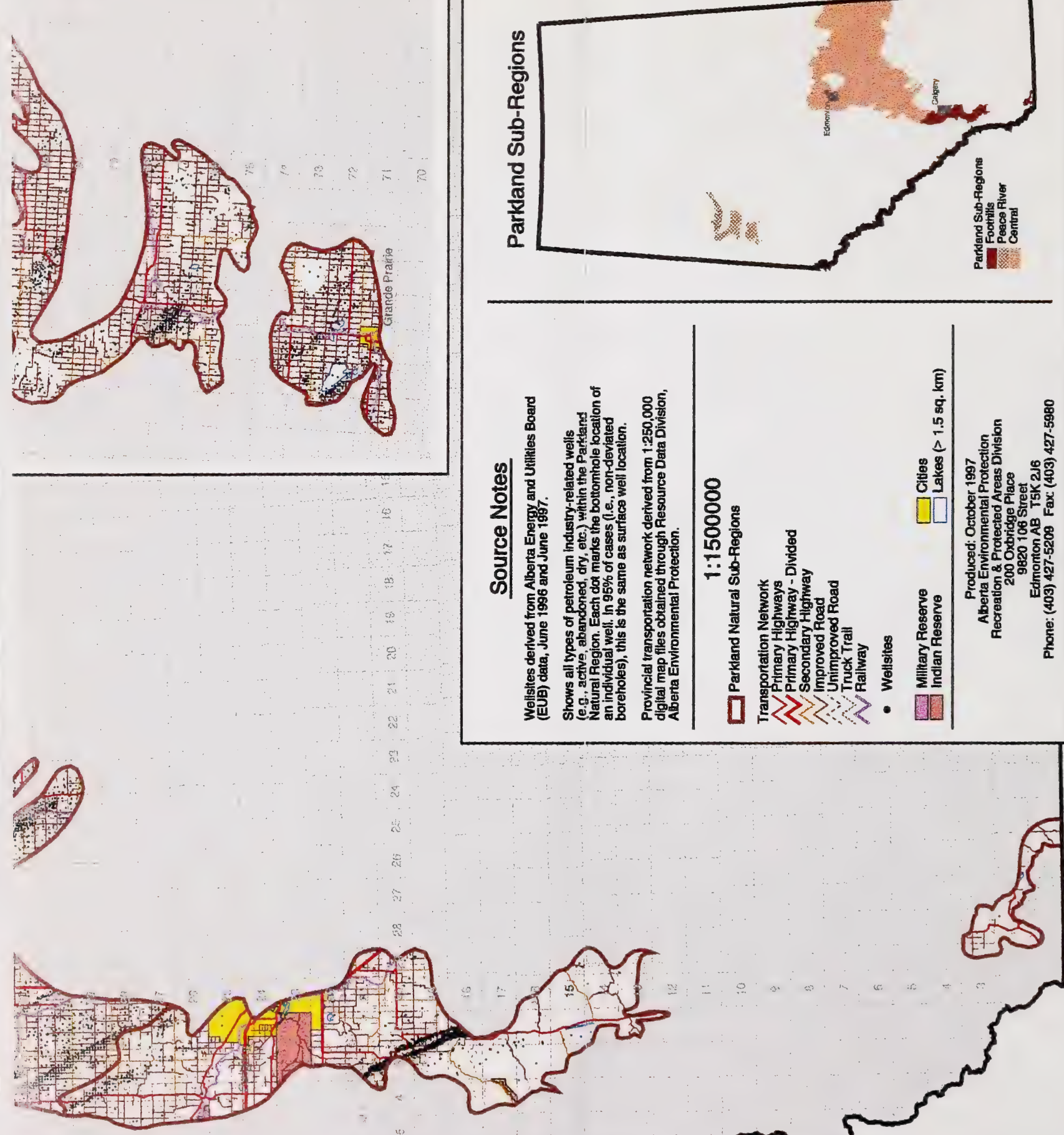


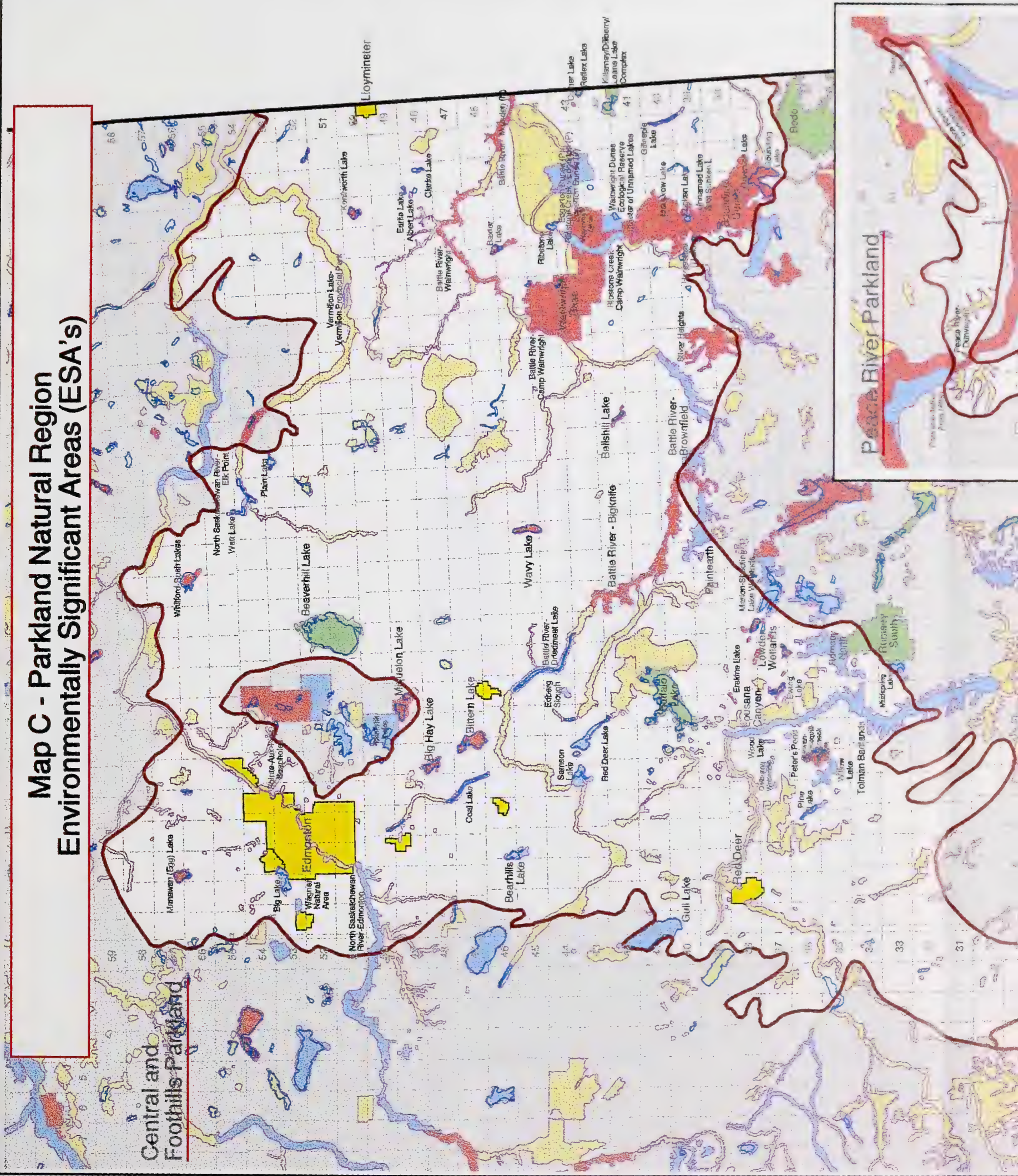




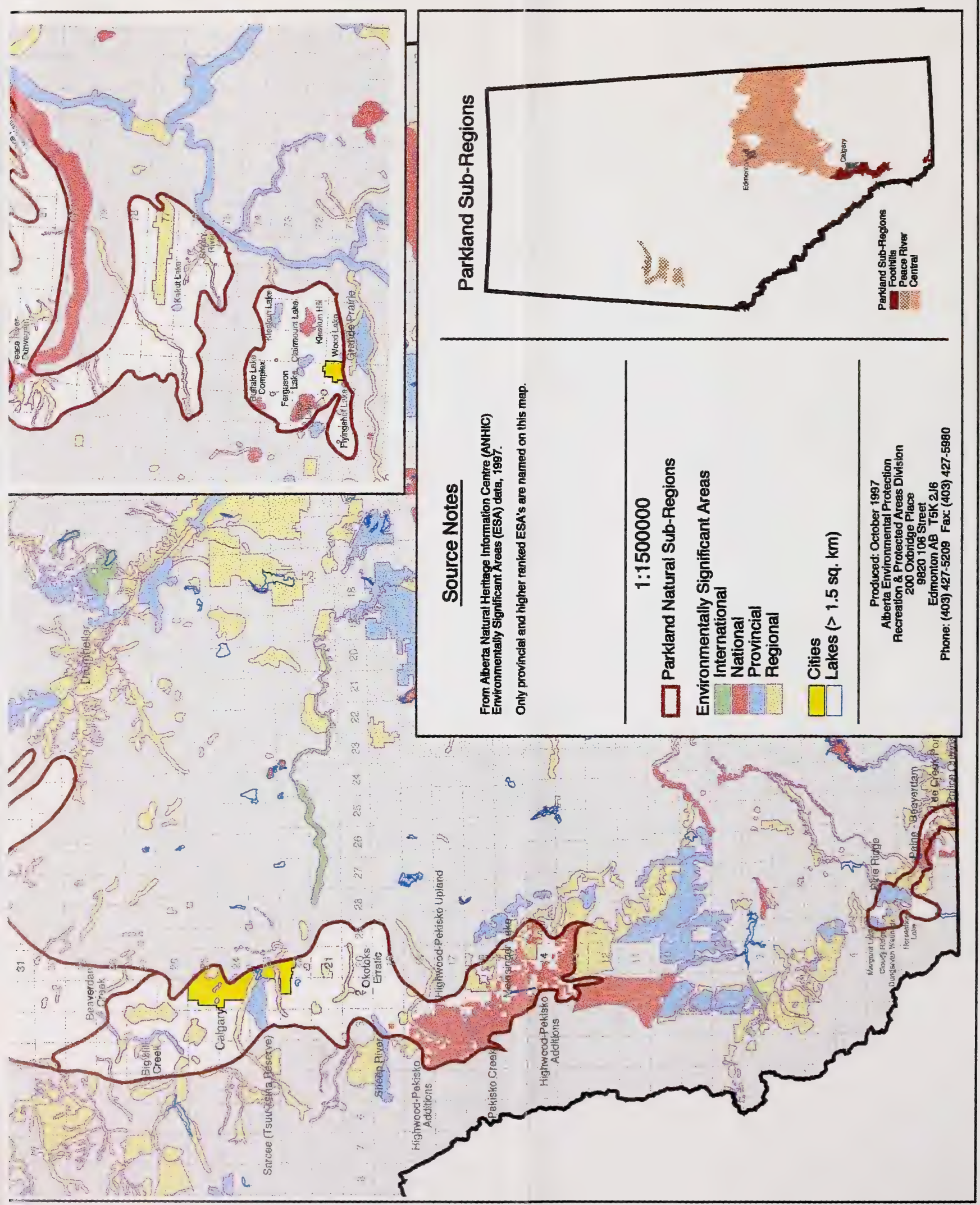




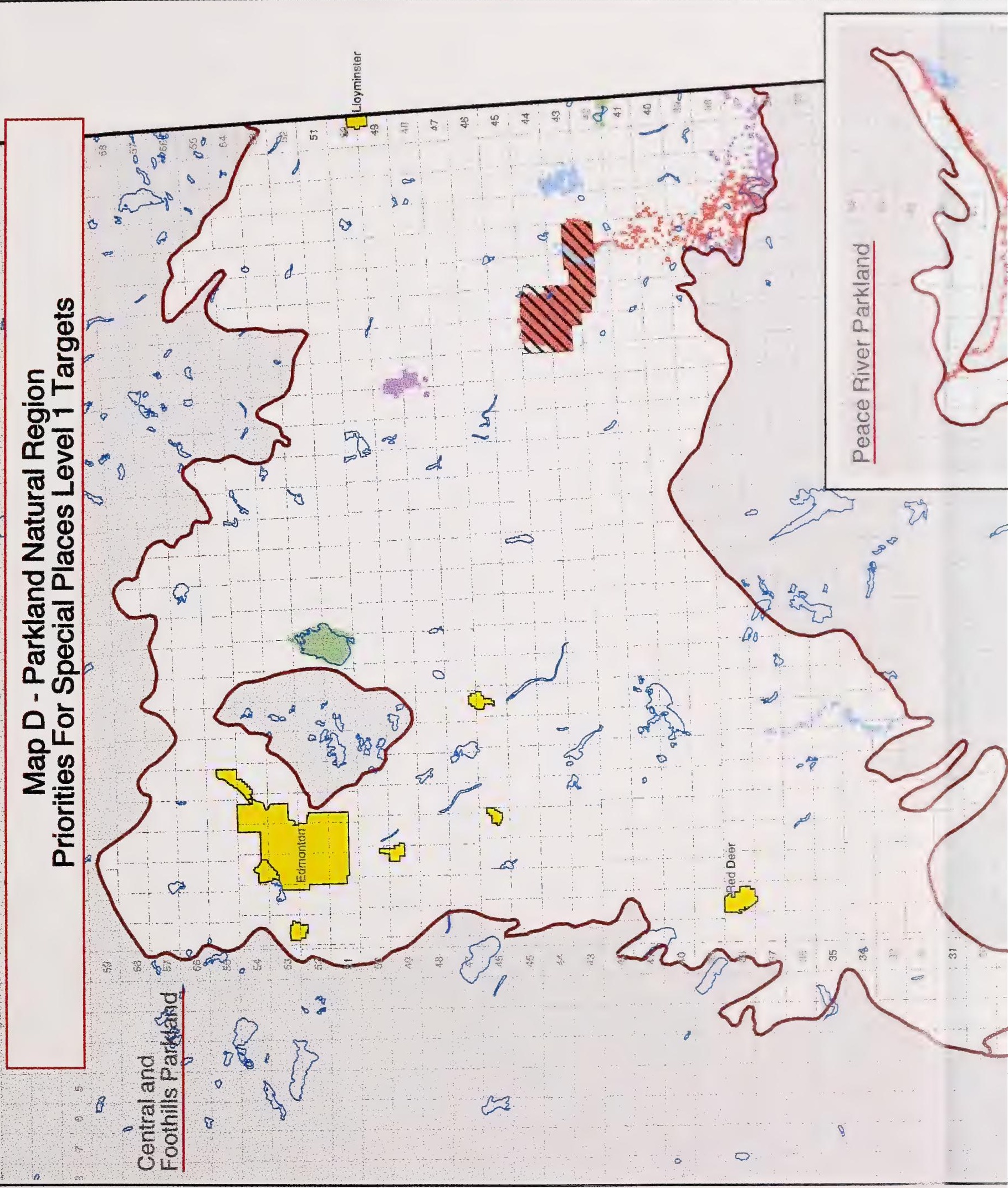




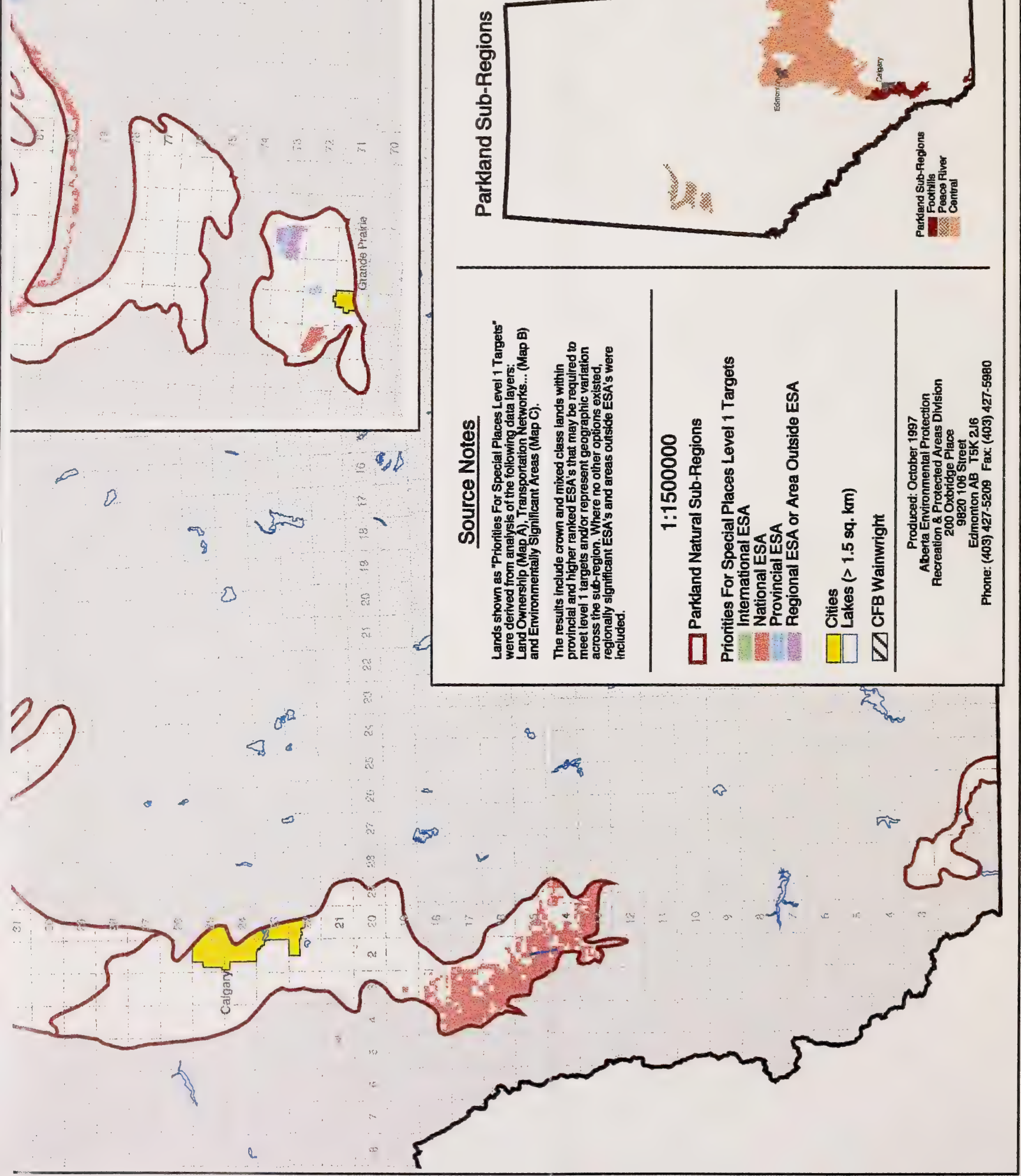




National Library of Canada

Bibliothèque nationale du Canada

3 3286516326408 